\title{
Evidence of C-F...H-C Attractive Interaction: Enforced Coplanarity of Tetrafluorophenylene-Ethynylene-Linked Porphyrin Dimer
}

\author{
Mitsuhiko Morisue, ${ }^{*, a}$ Miho Kawanishi, ${ }^{a}$ Ikuya Ueno, ${ }^{a}$ Takashi Nakamura, ${ }^{b}$ Tatsuya Nabeshima, ${ }^{b}$ \\ Kouki Imamura, ${ }^{c}$ and Koichi Nozakic ${ }^{c}$ \\ a. Faculty of Molecular Chemistry and Engineering, Kyoto Institute of Technology, Matsugasaki, Sakyo-ku, Kyoto 606-8585, Japan. \\ E-mail:morisue@kit.ac.jp \\ b. Faculty of Pure and Applied Sciences and Tsukuba Research Center for Energy Materials Science (TREMS), University of Tsukuba, \\ 1-1-1 Tennodai, Tsukuba, lbaraki 305-8571, Japan \\ c. Graduate School of Science and Engineering, University of Toyama, 3190 Gofuku, Toyama 930-8555, Japan.
}

\section{Contents:}

1. Electronic and photophysical study

2. Computational study using density functional theory

3. Self-aggregation behaviours

\section{Electronic and Photophysical Properties}

\subsection{Assignment of electronic absorption bands}

As described in the main text, 1 forms a double-strand with a significant order of binding strength in cyclohexane. In toluene, on the other hand, 1 was amenable the Beer's law at least up to $9.1 \times 10^{-6} \mathrm{M}$ (Figure S1), while 1 adopted the double-stranded form at higher concentrations (vide infra, Figure S16). Upon elevating temperature up to $343 \mathrm{~K}$, both the Soret and Q bands of 1 showed marginal hypsochromic shift, suggesting the persistence of coplanar conformation (Figure S2). Thermally robust spectral shape of $\mathbf{1}$ also supports that $\mathbf{1}$ dominantly adopts a single-strand form in toluene. 

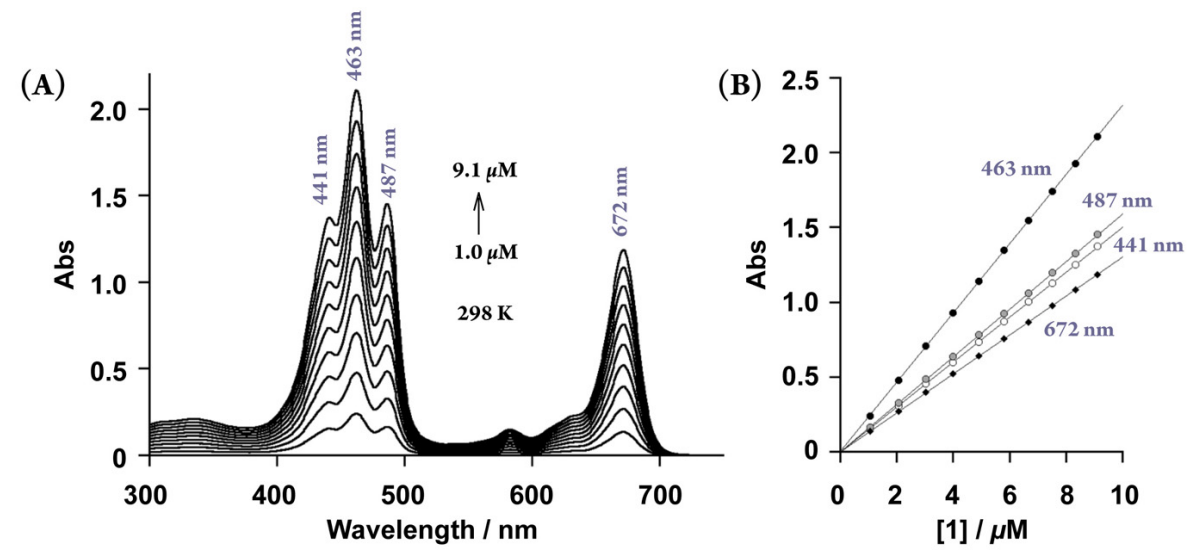

Figure S1. Electronic absorption spectra of $1\left(1.0 \times 10^{-6} \mathrm{M}\right.$ up to $\left.9.1 \times 10^{-6} \mathrm{M}\right)$ in toluene at $298 \mathrm{~K}(\mathrm{~A})$, and the plot of absorbance at the absorption maxima at $441,463,487$, and $672 \mathrm{~nm}$ with the least-square fitting lines assuming $\varepsilon_{441}=1.30 \times 10^{5}, \varepsilon_{463}=2.32 \times 10^{5}$, $\varepsilon_{487}=1.50 \times 10^{5}$, and $\varepsilon_{672}=1.59 \times 10^{5} \mathrm{M}^{-1} \mathrm{~cm}^{-1}$.

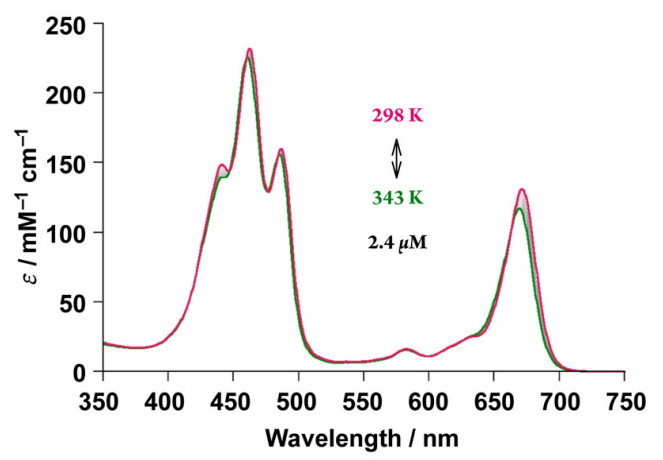

Figure S2. Variable-temperature electronic absorption spectra of $1(2.4 \mu \mathrm{M})$ in toluene.

The electronic absorption spectra mirror the sum of the electronic structures of the statistically distributed conformers. The deconvoluted absorption bands of $\mathbf{1}$ and $\mathbf{2}$ are roughly resolved to the coplanar and orthogonal conformer, based on the torsional angle-dependence in the energy level diagram produced by TD-DFT calculations (Figure S3). The split Soret bands are explained by the Kasha's molecular exciton theory, ${ }^{\$ 1, \mathrm{~S} 2}$ the fully coplanar conformer maximizes the constructive exciton coupling leading to the bathochromic shift of the Soret band (red allows) and, concurrently, the destructive coupling resulting in hypsochromic shift (blue allows) (Figure S3E). On the other hand, the orthogonally twisted conformer mitigates the exciton coupling between two porphyrin ring, in which the electronic transition dipole moments perpendicular to the long axis are arranged in a mutually orthogonal manner, and therefore, the Soret band remains nearly degenerated. 

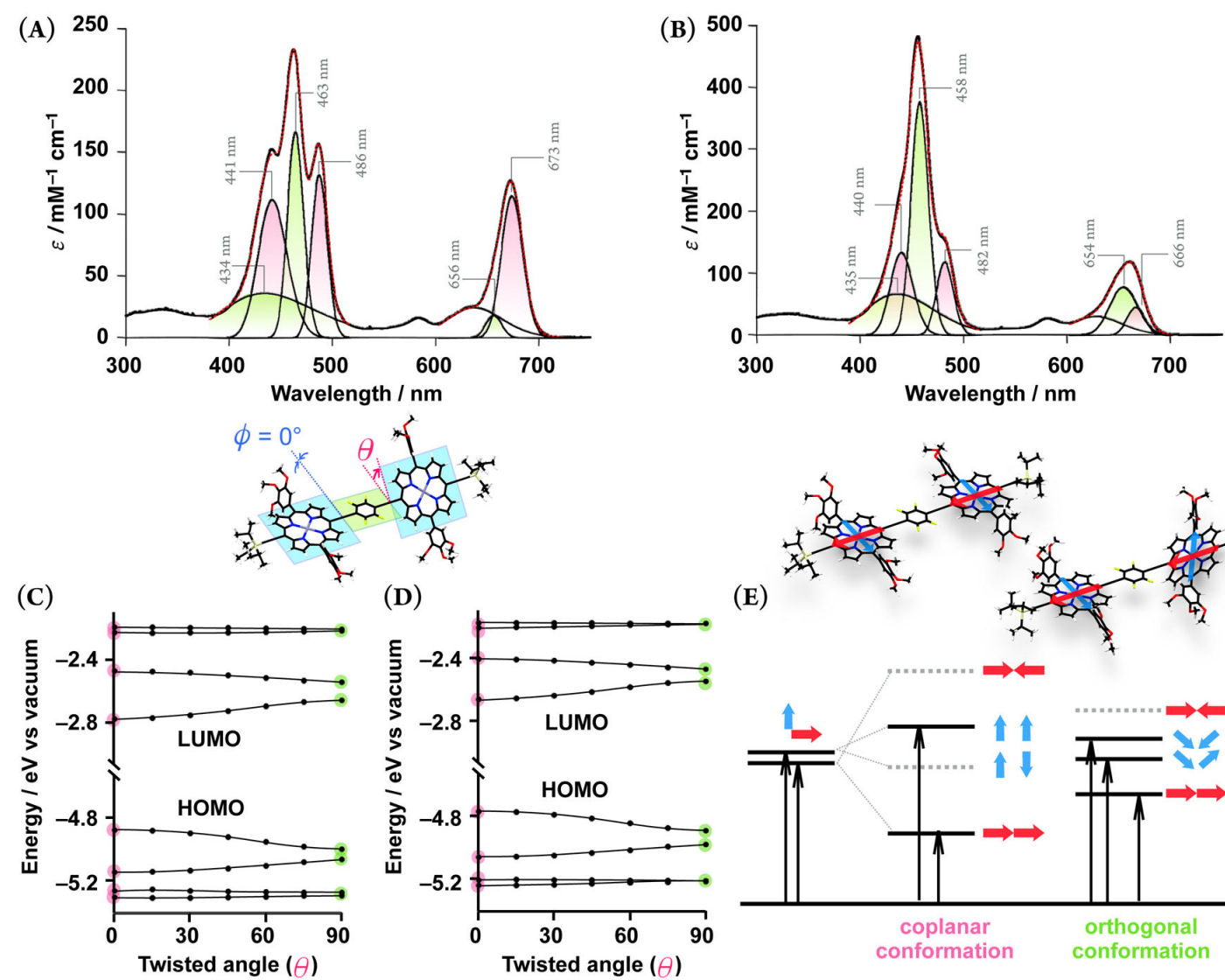

(E)

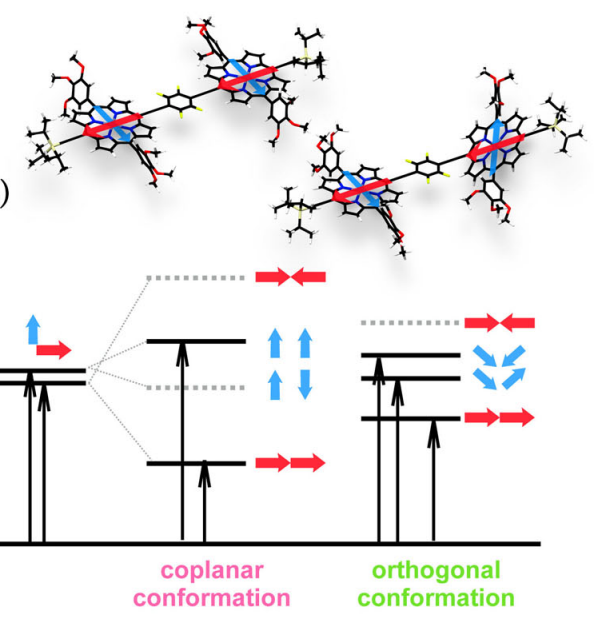

Figure S3. Deconvoluted electronic absorption spectra of 1 (A) and 2 (B) in toluene, with which Gauss curves are assigned to the coplanar (pink) and orthogonal conformer (green). Torsional-angle-dependence of energy diagram of 1 (C) and 2 (D) estimated by TD-DFT calculations at the B3LYP/6-31G(d) level. Schematic energy diagram of the coplanar and torsional conformers based on the molecular exciton theory $(\mathrm{E})$.

\subsection{Supramolecular ladder complex formation}

We investigated the effect of pyridine as an axially coordinating ligand to the central zinc of the porphyrin ring. In toluene, titration experiments of $\mathbf{1}$ and $\mathbf{2}$ with pyridine were conducted. In the course of addition of pyridine, all the absorption maxima shifted to the red, in line with the typical signature of axial coordination of pyridine to zinc porphyrin (Figure S4). Spectral changes showed pseudo-isosbestic points, and the titration isotherms were analyzed by global fittings assuming a stepwise coordination of pyridine to 1 and 2. It was estimated that pyridine bound to 1 with $K_{1 \mathrm{~L}}=(9.79 \pm 0.11) \times 10^{4} \mathrm{M}^{-1}$ and $K_{2 \mathrm{~L}}=(1.52 \pm 0.12) \times$ $10^{4} \mathrm{M}^{-1}$, and to 2 with $K_{1 \mathrm{~L}}=(6.58 \pm 0.29) \times 10^{4} \mathrm{M}^{-1}$ and $K_{2 \mathrm{~L}}=(1.16 \pm 0.09) \times 10^{4} \mathrm{M}^{-1}$. The binding strengths are ranged in a moderate magnitude. ${ }^{\mathrm{S} 3}$ The Soret and $\mathrm{Q}$ bands of $\mathbf{1}$ and $\mathbf{2}$ remained similar band widths in the course of the addition of pyridine, and fluorescence intensity also substantially unchanged. The spectral changes suggest that axially coordinating pyridine involves no substantial effect on the distributions of the torsional conformation. 


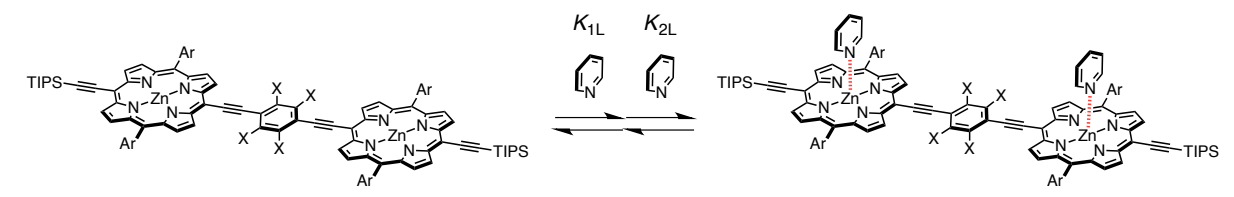

Scheme S1. Stepwise axial coordination of pyridine to 1 or $2\left(K_{1 \mathrm{~L}}=[\mathbf{1} \cdot \mathrm{Py}] /[1][\mathrm{Py}]\right.$ and $K_{2 \mathrm{~L}}=[\mathbf{1} \cdot \mathrm{Py} 2] /[1 \cdot \mathrm{Py}][\mathrm{Py}]$, or $K_{1 \mathrm{~L}}=$ [2·Py]/[2][Py] and $\left.K_{2 \mathrm{~L}}=\left[\mathbf{2} \cdot \mathrm{Py}_{2}\right] /[\mathbf{2} \cdot \mathrm{Py}][\mathrm{Py}]\right)$.
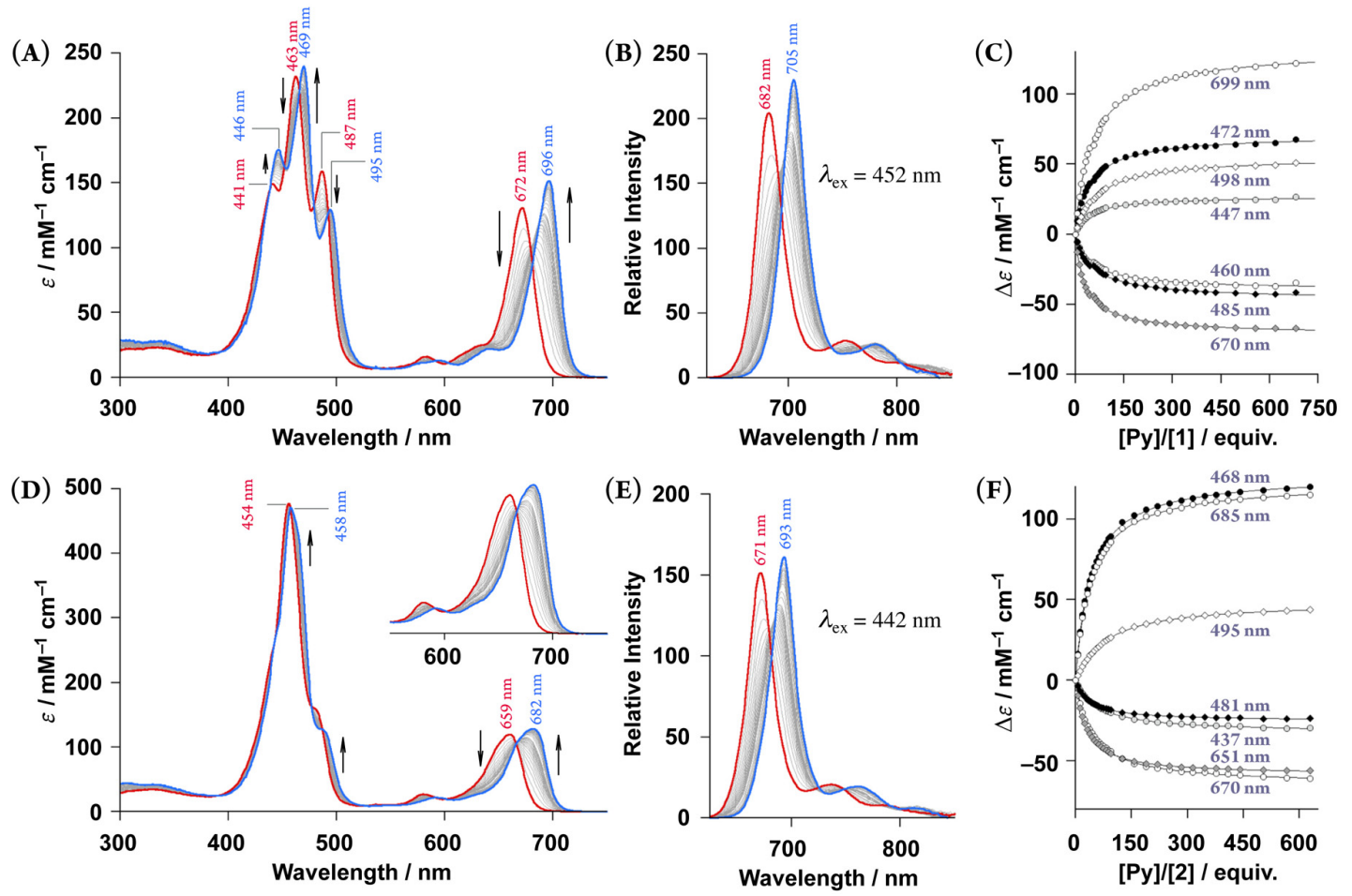

Figure S4. Spectrometric titration of $1\left([1]_{0}=6.7 \times 10^{-7} \mathrm{M}\right.$, dilution up to $\left.4.9 \times 10^{-7} \mathrm{M}\right)$ with pyridine from $0 \mathrm{M}$ up to $3.3 \times 10^{-4} \mathrm{M}$ (red to blue) at $298 \mathrm{~K}$ in toluene (A), fluorescence spectra obtained by excitation at $452 \mathrm{~nm}$ as the pseudo-isosbestic point (B), and global fitting analysis of the titration isotherms assuming a $1: 21 \cdot \mathrm{Py}_{2}$ complex formation with $K_{1 \mathrm{~L}}=(9.79 \pm 0.11) \times 10^{4} \mathrm{M}^{-1}$ and $K_{2 \mathrm{~L}}$ $=(1.52 \pm 0.12) \times 10^{4} \mathrm{M}^{-1}(\mathrm{C})$. Analogous spectrometric titration of $2\left([2]_{0}=6.6 \times 10^{-7} \mathrm{M}\right.$, dilution up to $\left.4.8 \times 10^{-7} \mathrm{M}\right)$ with pyridine from $0 \mathrm{M}$ up to $3.3 \times 10^{-4} \mathrm{M}$ (red to green) at $298 \mathrm{~K}$ in toluene (D), fluorescence spectra obtained by excitation at $442 \mathrm{~nm}$ as the pseudo-isosbestic point (E), and global fitting analysis of the titration isotherms assuming a 1:2 2.Py2 complex formation with $K_{1 \mathrm{~L}}=$ $(6.58 \pm 0.29) \times 10^{4} \mathrm{M}^{-1}$ and $K_{2 \mathrm{~L}}=(1.16 \pm 0.09) \times 10^{4} \mathrm{M}^{-1}(\mathrm{~F})$.

To observe the fully coplanar conformation of $\mathbf{2}$, we attempted the formation of the ladder complex, i.e., $\mathbf{2}_{2} \cdot$ bpy 2 consisting of two porphyrin dimers with two $4,4^{\prime}$-bipyridine bidentate ligands (Scheme S2), as established by Anderson and coworkers. ${ }^{\text {S4-S6 }}$ Two 4,4'-bipyridne ligands could doubly bridges two porphyrin dimers 1 and $\mathbf{2}$ via four points pyridyl-to-zinc axial coordination bonds and form the ladder complex. Spectrometric titration experiments of 1 and 2 with 4,4'-bipyridine in toluene (Figure S5). The spectral changes through several pseudo-isosbestic points were analyzed by global fitting of titration isotherms assuming $K_{\text {Ladder }}=(1.85 \pm 0.28) \times 10^{18} \mathrm{M}^{-3}$ and $K_{\text {unzip }}=(3.64 \pm 0.30) \times 10^{5} \mathrm{M}^{-1}$ for 1 , and $K_{\text {Ladder }}$ $=(3.91 \pm 1.05) \times 10^{18} \mathrm{M}^{-3}$ and $K_{\text {unzip }}=(2.36 \pm 0.18) \times 10^{5} \mathrm{M}^{-1}$ for 2 , in good agreement with the reported binding strengths. ${ }^{\mathrm{S} 5}$ The ladder complex formation is too preferable to observe of the conformational effect 
on the binding behaviors of 4,4'-bipyridine to $\mathbf{1}$ or $\mathbf{2}$. Therefore, the ladder complexes likely formed in the presence of approximately equivalent amount of 4,4'-bipyridine. However, the intramolecular electronic communication among two terminal porphyrin rings remained substantially disrupted, suggesting that the torsional rotation of the central phenylene group was not frozen. In this consequence, the spectral change upon the ladder complex formation only mirrored the effect of the axially coordinating ligand. Thermodynamic analyses with pyridyl ligands are summarized in Table S1.

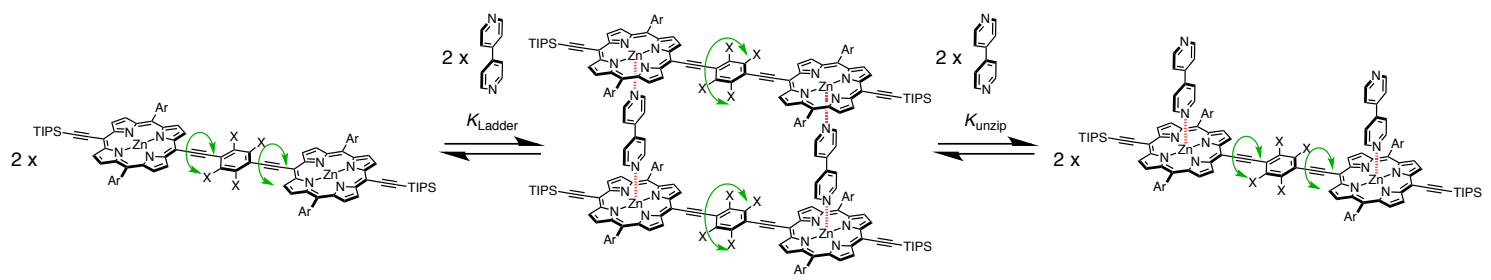

Scheme S2. Possible equilibrium of ladder complex formation of $\mathbf{1}$ or $\mathbf{2}$ with $4,4^{\prime}$-bipyridine $\left(K_{\text {Ladder }}=\left[\mathbf{1}_{2} \cdot\right.\right.$ bpy 2$] /[\mathbf{1}]^{2}[\mathrm{bpy}]^{2}$ and $K_{\text {unzip }}$ $=\left[\mathbf{1} \cdot \mathrm{bpy}_{2}\right] /\left[\mathbf{1}_{2} \cdot \mathrm{bpy}_{2}\right][\mathrm{bpy}]^{2}$, or $K_{\text {Ladder }}=\left[\mathbf{2}_{2} \cdot \mathrm{bpy}_{2}\right] /[\mathbf{2}]^{2}[\mathrm{bpy}]^{2}$ and $\left.K_{\text {unzip }}=\left[\mathbf{2} \cdot \mathrm{bpy}_{2}\right] /\left[\mathbf{2}_{2} \cdot \mathrm{bpy}_{2}\right][\mathrm{bpy}]^{2}\right)$.
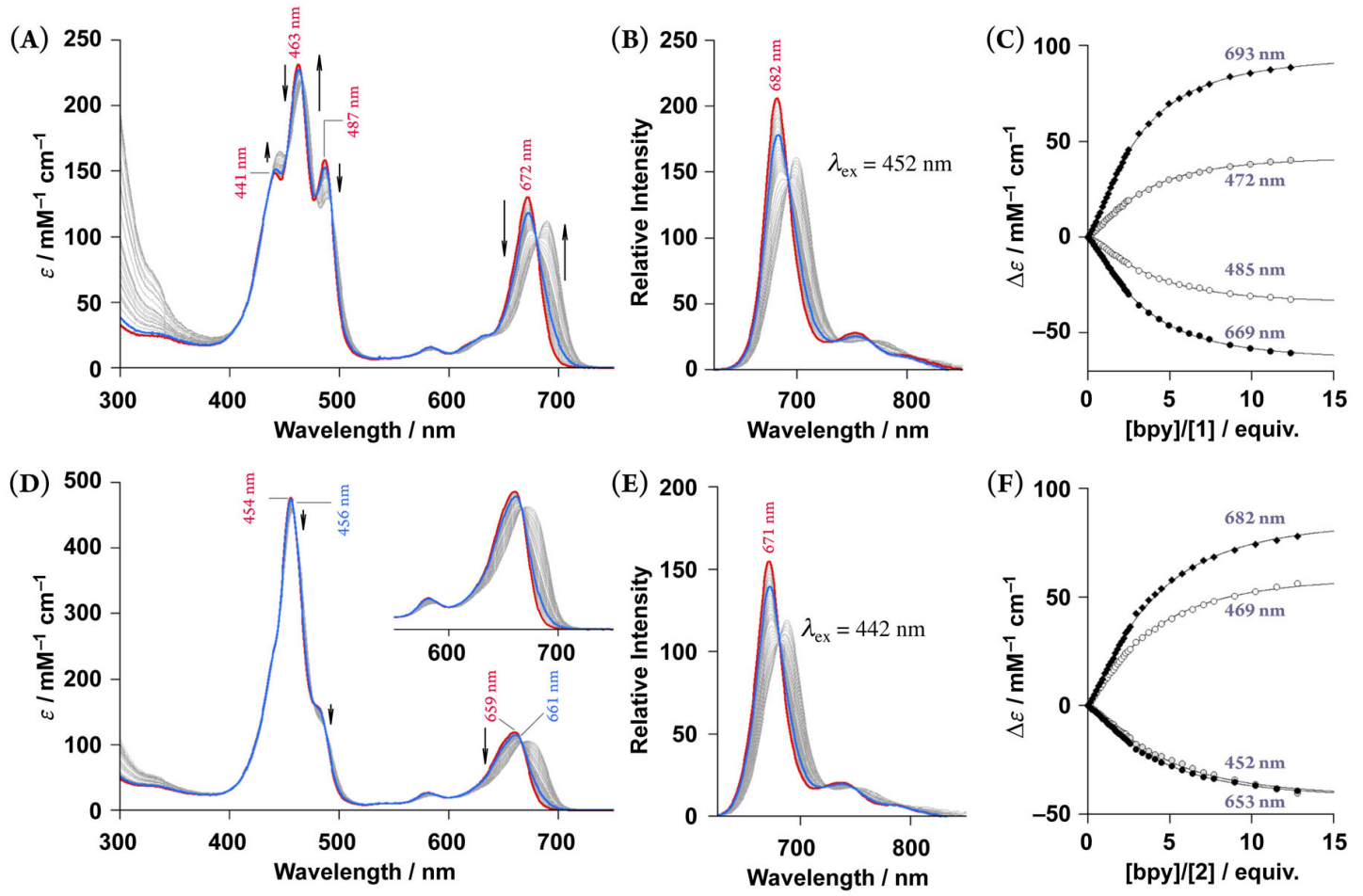

Figure S5. Spectrometric titration of $1\left([1]_{0}=6.6 \times 10^{-7} \mathrm{M}\right.$, dilution up to $\left.5.0 \times 10^{-7} \mathrm{M}\right)$ with $4,4^{\prime}$-bipyridine from $0 \mathrm{M}$ up to $3.3 \times$ $10^{-4} \mathrm{M}$, (red to grey via blue = ca. 1 equiv with maximal population of the ladder complex) at $298 \mathrm{~K}$ in toluene (A), fluorescence spectra obtained by excitation at $452 \mathrm{~nm}$ as the pseudo-isosbestic point (B), and global fitting analysis of the titration isotherms assuming a 2:2 $\mathbf{1}_{2} \cdot \mathrm{bpy}_{2}$ complex formation with $K_{\text {Ladder }}=(1.85 \pm 0.28) \times 10^{18} \mathrm{M}^{-3}$ and subsequent dissociation with $K_{\text {unzip }}=(3.64 \pm$ $0.30) \times 10^{5} \mathrm{M}^{-1}(\mathrm{C})$. Analogous spectrometric titration of $2\left([2]_{0}=6.4 \times 10^{-7} \mathrm{M}\right.$, dilution up to $\left.4.8 \times 10^{-7} \mathrm{M}\right)$ with $4,4^{\prime}-$ bipyridine from $0 \mathrm{M}$ up to $6 \times 10^{-6} \mathrm{M}$ (red to grey via blue = ca. 1 equiv with maximal population of the ladder complex) at $298 \mathrm{~K}$ in toluene (D), fluorescence spectra obtained by excitation at $442 \mathrm{~nm}$ as the pseudo-isosbestic point (E), and global fitting analysis of the titration isotherms assuming a 2:2 2 2 bpy2 complex formation with $K_{\text {Ladder }}=(3.91 \pm 1.05) \times 10^{18} \mathrm{M}^{-3}$ and subsequent dissociation with $K_{\text {unzip }}=$ $(2.36 \pm 0.18) \times 10^{5} \mathrm{M}^{-1}(\mathrm{~F})$. 
Table S1. Binding constants for axial coordination of pyridine and ladder complex formation of $\mathbf{1}$ and 2 at $298 \mathrm{~K}$ in toluene.

\begin{tabular}{|c|c|c|c|c|}
\hline \multirow{2}{*}{} & \multicolumn{2}{|c|}{ Pyridine } & \multicolumn{2}{c|}{$4,4^{\prime}$-Bipyridine } \\
\cline { 2 - 5 } & $K_{1 \mathrm{~L}} / \mathrm{M}^{-1}$ & $K_{2 \mathrm{~L}} / \mathrm{M}^{-1}$ & $K_{\text {Ladder }} / \mathrm{M}^{-3}$ & $K_{\text {unzip }} / \mathrm{M}^{-1}$ \\
\hline $\mathbf{1}$ & $(9.79 \pm 0.11) \times 10^{4}$ & $(1.52 \pm 0.12) \times 10^{4}$ & $(1.85 \pm 0.28) \times 10^{18}$ & $(3.64 \pm 0.30) \times 10^{5}$ \\
\hline $\mathbf{2}$ & $(6.58 \pm 0.29) \times 10^{4}$ & $(1.16 \pm 0.09) \times 10^{4}$ & $(3.91 \pm 1.05) \times 10^{18}$ & $(2.36 \pm 0.18) \times 10^{5}$ \\
\hline
\end{tabular}

\subsection{Photodynamic experiments}

It is known that the photoexcited meso-ethynylene-conjugated porphyrin dimers are relaxed to the coplanar conformation due to the enhanced contribution of the quinoid-cumulene conjugation (Scheme 1). This can be seen as the bonding character of the $p$ orbital on the $\mathrm{C}\left(s p^{2}\right)-\mathrm{C}(s p)$ single bonds at the LUMO level, while that is antibonding at the HOMO level (Figure S16, vide infra). Fluorescence decay profiles of $\mathbf{1}$ and $\mathbf{2}$ at the shorter and longer wavelengths were verified by selective excitation of the twisted conformers at 450 $\mathrm{nm}$ by means of TCSPC measurements (Figure S6-S7, and Table S2). The fast decay constants at the shorter wavelengths and the concomitant rise at the longer wavelengths were found for $\mathbf{1}$ and $\mathbf{2}$, as likely assigned to the torsional coplanarization. The assignment was supported by the slower decay time constants in phenylcyclohexane as a viscous medium (Table S2). The conformational relaxation of 1 was slightly faster than 2. This may be relevant to the slightly greater lobes of the bonding $p$ orbitals on the $\mathrm{C}\left(s p^{2}\right)-$ $\mathrm{C}(s p)$ single bonds of $\mathbf{1}$ than those of $\mathbf{2}$ at the LUMO level (Figure S16). The significantly smaller proportion of the twisted conformer in $\mathbf{1}$ than that in $\mathbf{2}$ rationalized the discrepancy between the molar absorptivity of $\mathbf{2}$ larger than $\mathbf{1}$ but nearly identical fluorescent properties of $\mathbf{1}$ and $\mathbf{2}$ from the Strickler-Berg equation; both absorption coefficient $(\varepsilon)$ and radiative rate constant $\left(k_{\mathrm{em}}\right)$ are proportional to the oscillator strengths as described as $k_{\mathrm{em}} \propto \int \varepsilon \mathrm{d} \ln \tilde{v} \cdot{ }^{\mathrm{S7}}$ Although the TCSPC experiments were conducted under the very dilute conditions in the order of $10^{-6} \mathrm{M}$, marginal decay components with relatively longer life time may be arising from excimer. The TCSPC measurements by selective excitation of the twisted conformers revealed the similar excited-state torsional relaxation processes of $\mathbf{1}$ and $\mathbf{2}$ as well as the contrasting groundstate proportions of the fully coplanar and twisted conformers in $\mathbf{1}$ and $\mathbf{2}$.

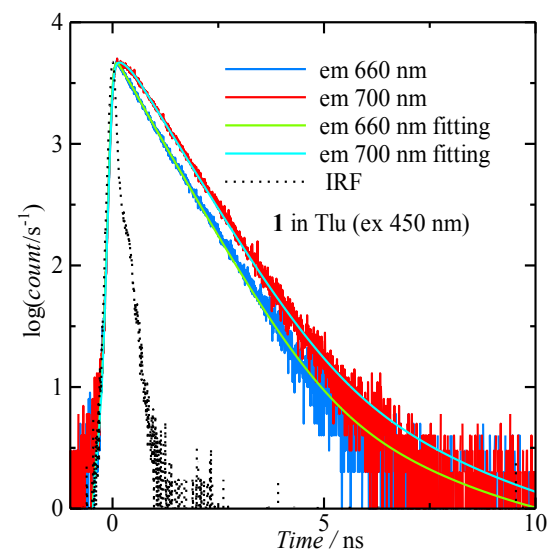

Figure S6. Fluorescence decay profiles of 1 at 660 an (blue) and $700 \mathrm{~nm}$ (red) together with instrument response function (dotted line) in toluene. 


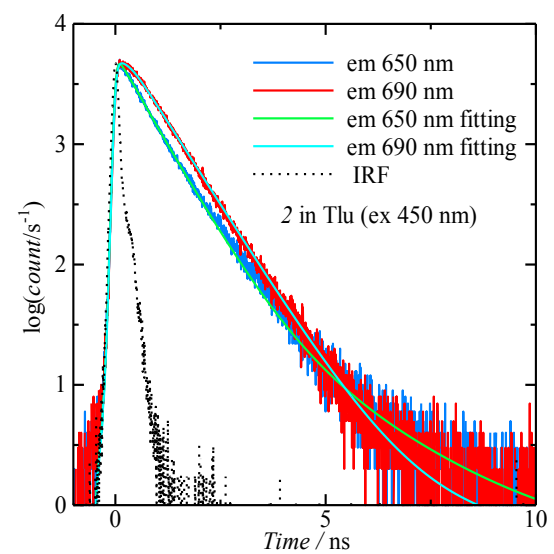

Figure S7. Fluorescence decay profiles of 2 at $650 \mathrm{~nm}$ (blue) and $690 \mathrm{~nm}$ (red) together with instrument response function (dotted line) in toluene.

Table S2. Fluorescence decay constants $(\tau)$ and fluorescence quantum yields $(\Phi)$ of $\mathbf{1}$ and $\mathbf{2}$ observed by excitation at $450 \mathrm{~nm}$ in toluene and phenylcyclohexane.

\begin{tabular}{|c|c|c|c|c|c|c|c|c|}
\hline & \multicolumn{4}{|c|}{$\begin{array}{c}\text { Toluene } \\
\eta=0.59 \mathrm{mPa} \cdot \mathrm{s}, \mathrm{E}_{\mathrm{T}}(30)=33.9\end{array}$} & \multicolumn{4}{|c|}{$\begin{array}{c}\text { Phenylcyclohexane } \\
\eta=3 \mathrm{mPa} \cdot \mathrm{s}, \mathrm{E}_{\mathrm{T}}(30)=34.2\end{array}$} \\
\hline & at sh & $\begin{array}{c}\tau / \mathrm{ns} \\
\text { rter wavelength }\end{array}$ & & $\begin{array}{l}\tau / \mathrm{ns} \\
\text { ger wavelength }\end{array}$ & & $\begin{array}{c}\tau / \text { ns } \\
\text { rter wavelength }\end{array}$ & & $\begin{array}{c}\tau / \mathrm{ns} \\
\text { ger wavelength }\end{array}$ \\
\hline 1 & $\begin{array}{l}660 \\
\mathrm{~nm}\end{array}$ & $\begin{array}{c}0.168(0.303) \\
0.729(0.693) \\
2.39(0.005)\end{array}$ & $\begin{array}{l}700 \\
\mathrm{~nm}\end{array}$ & $\begin{array}{c}0.168(-0.208) \\
0.821(0.993) \\
2.39(0.007)\end{array}$ & $\begin{array}{l}660 \\
\mathrm{~nm}\end{array}$ & $\begin{array}{c}0.337(0.408) \\
0.847(0.586) \\
2.65(0.006)\end{array}$ & $\begin{array}{l}700 \\
\mathrm{~nm}\end{array}$ & $\begin{array}{c}0.337(-0.083) \\
0.847(0.896) \\
2.65(0.021)\end{array}$ \\
\hline 2 & $\begin{array}{l}650 \\
\mathrm{~nm}\end{array}$ & $\begin{array}{c}0.211(0.319) \\
0.736(0.666) \\
1.92(0.006)\end{array}$ & $\begin{array}{l}690 \\
\mathrm{~nm}\end{array}$ & $\begin{array}{c}0.211(-0.204) \\
0.736(0.996) \\
1.92(0.004)\end{array}$ & $\begin{array}{l}650 \\
\mathrm{~nm}\end{array}$ & $\begin{array}{c}0.355(0.352) \\
0.890(0.645) \\
4.87(0.003)\end{array}$ & $\begin{array}{l}690 \\
\mathrm{~nm}\end{array}$ & $\begin{array}{c}0.355(0.066) \\
0.890(0.927) \\
4.87(0.07)\end{array}$ \\
\hline
\end{tabular}

Solvent-effect on the electronic absorption spectra is usually described in the solvent polarity parameter, $\mathrm{ET}_{\mathrm{T}}(30)$ as the standard index. ${ }^{\mathrm{S} 8}$ Solvent-persistent electronic absorption spectra of $\mathbf{1}$ and $\mathbf{2}$ in toluene and in phenylcyclohexane (Figure S8) indicated not only the marginal solvent polarity effect in the electronic structures but also the negligible viscosity effect on the ground-state conformational distributions. The aromatic solvents solvated $\mathbf{1}$ slightly stronger than $\mathbf{2}$ due to the quadrupolar interaction (Table S3, vide infra). 

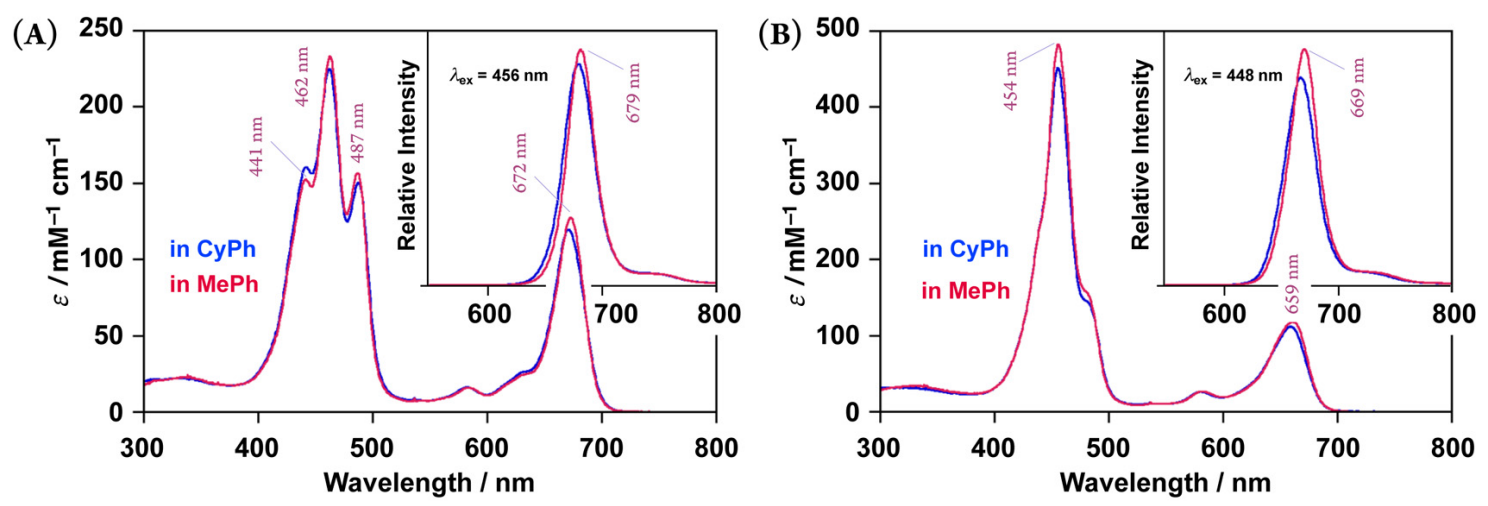

Figure S8. Electronic absorption and fluorescence spectra of $\mathbf{1}\left([\mathbf{1}]=7.2 \times 10^{-7} \mathrm{M}, \mathrm{A}\right)$ and 2 ([2] $\left.=6.3 \times 10^{-7} \mathrm{M}, \mathrm{B}\right)$ in toluene (blue) and in phenylcyclohexane (red) at $298 \mathrm{~K}$. Fluorescence spectra were observed by the excitation at the isosbestic point (456 nm for 1 and $448 \mathrm{~nm}$ for 2 ). The absorption and fluorescence maxima in toluene are labeled.

Although both the twisted conformers of 1 and $\mathbf{2}$ showed the similar torsional relaxation, the proportions of the coplanar and twisted conformers may be observed in the excitation-wavelength dependence of fluorescence spectra. In the fluorescence-excitation correlation contour maps, 1 showed negligible excitation-wavelength-dependence of the fluorescence spectra in toluene (Figure S9A), while the spectral shape of fluorescence of $\mathbf{2}$ displayed a very small excitation-wavelength-dependence (Figure S10A). Phenylcyclohexane as the viscous medium emphasized the excited-state torsional relaxation. The excitation-wavelength-dependence of 2 was somewhat enhanced in phenylcyclohexane (Figure S10B), while that of 1 was only marginal (Figure S9B). The comparison elucidated that the proportion of the twisted conformer of $\mathbf{2}$ in the ground state was certainly greater than $\mathbf{1}$.
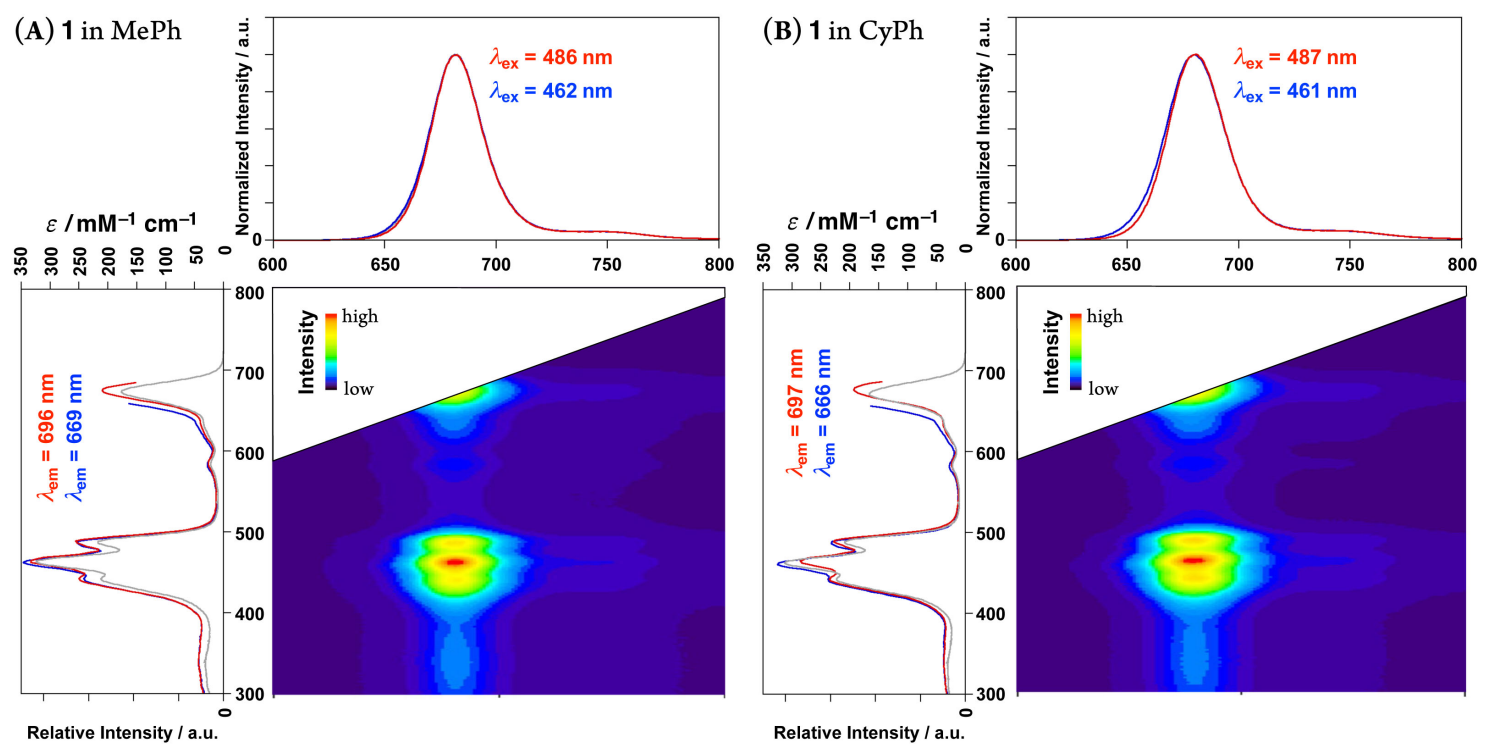

Figure S9. Fluorescence-excitation correlations of $1\left([1]=7.2 \times 10^{-7} \mathrm{M}\right)$ in toluene (A) and in phenylcyclohexane (B). The excitation spectra (left panel) were monitored at the shorter (blue) and longer (red) emission wavelength, where the emission intensity is half of the emission maxima, and the spectra are shown with the absorption spectrum (grey). The fluorescence spectra (top panel) were recorded by the excitation at the middle (blue) and longer (red) Soret band. 

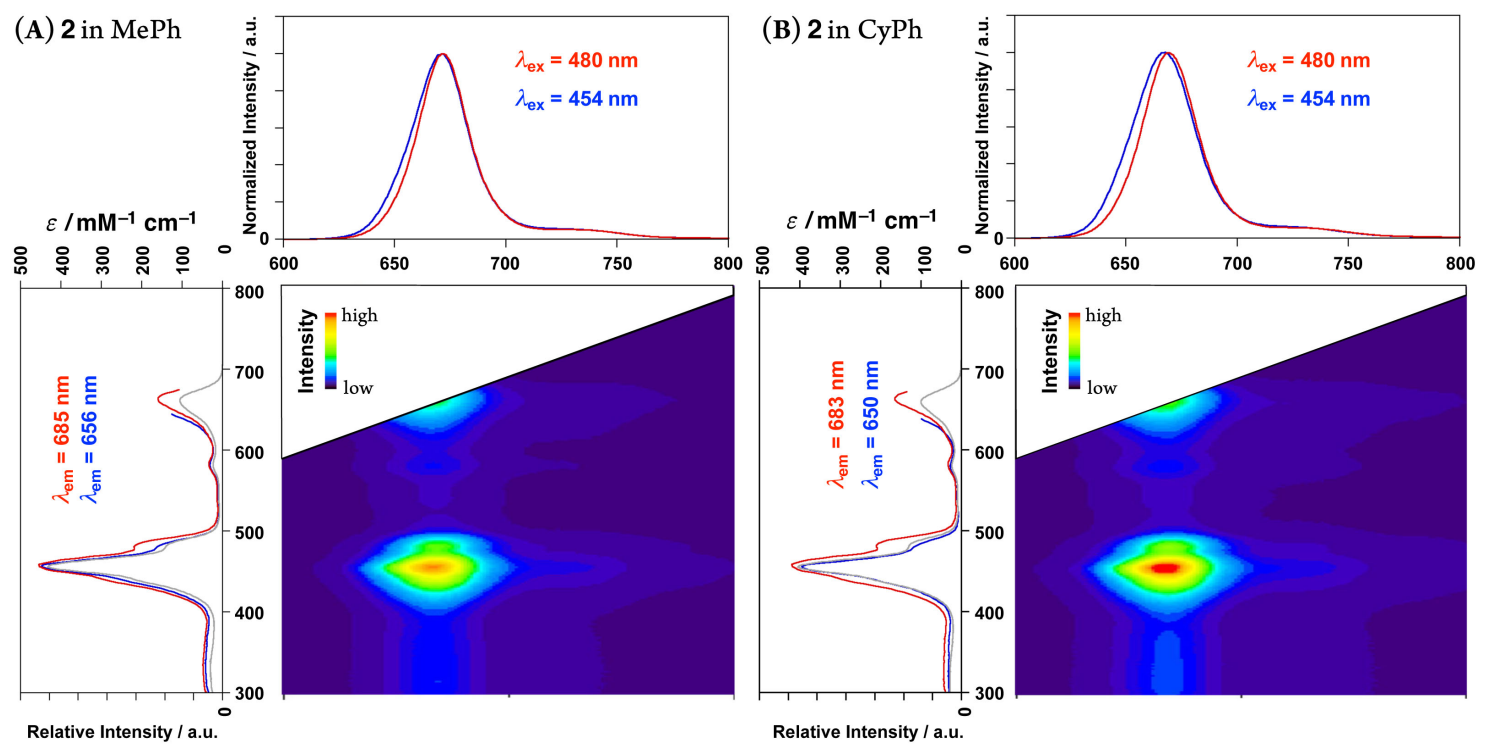

Relative Intensity / a.u.

Relative Intensity / a.u.

Figure S10. Fluorescence-excitation correlations of $2\left([2]=6.3 \times 10^{-7} \mathrm{M}\right)$ in toluene $(A)$ and in phenylcyclohexane (B). The excitation spectra (left panel) were monitored at the shorter (blue) and longer (red) emission wavelength, where the emission intensity is half of the emission maxima, and the spectra are shown with the absorption spectrum (grey). The fluorescence spectra (top panel) were recorded by the excitation at the middle (blue) and longer (red) Soret band.

\section{Computational Study Using Density Functional Theory}

Geometry-optimized structures of 1 and 2 were generated by DFT/B3LYP calculations using the 6-31G(d) basis set. The geometry optimization using the B3LYP-D3(BJ) functional, a dispersion-corrected method, ${ }^{\mathrm{S} 9.510}$ using the 6-311G(d) for zinc and the 6-31G(d) for the other atoms (Figure S12) and also using the 6-31G(d,p) basis set (Figure S13) generated coplanar structures similarly to those generated by B3LYP, suggesting that the dispersion-correction is subtle in $\mathbf{1}$ and $\mathbf{2}$. A close similarity in the bond-length equilibration of $\mathbf{1}$ and $\mathbf{2}$ suggested that the degree of the parent $\pi$-conjugation is in a similar level (Figure S11). 

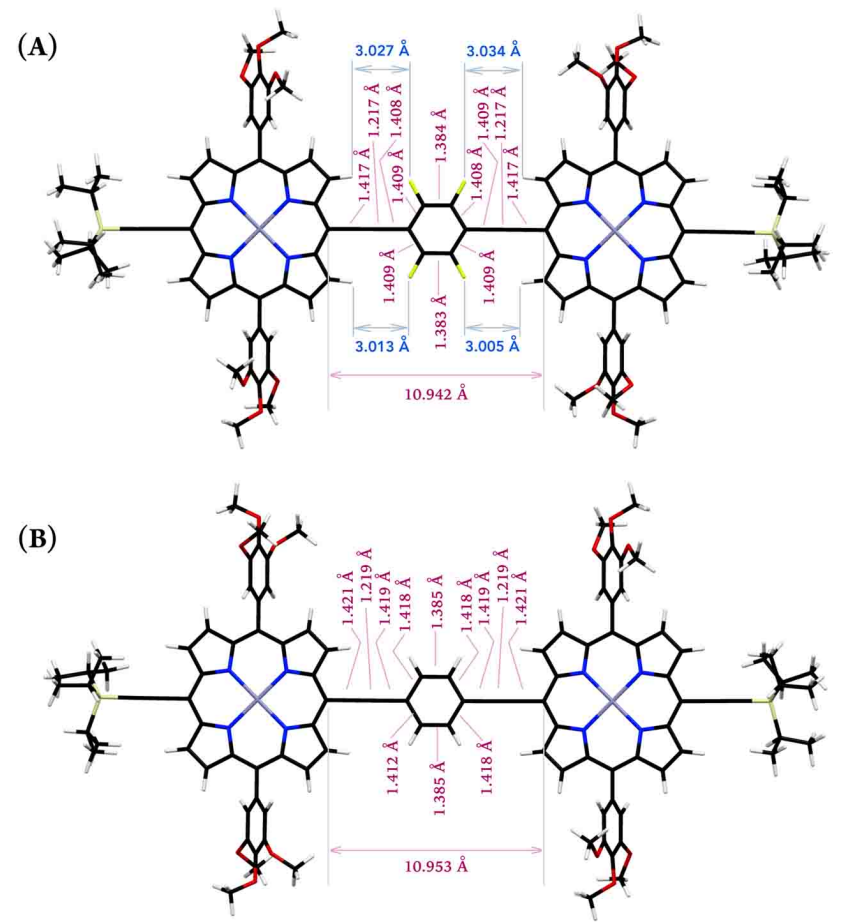

Figure S11. Geometry-optimized structures for 1 (A) and 2 (B) produced by DFT calculations at the B3LYP/6-31G(d) level. The C$\mathrm{C}$ bond lengths of the arylene-ethynylene linkages are marked. Cartesian coordinates are listed in Table S4.
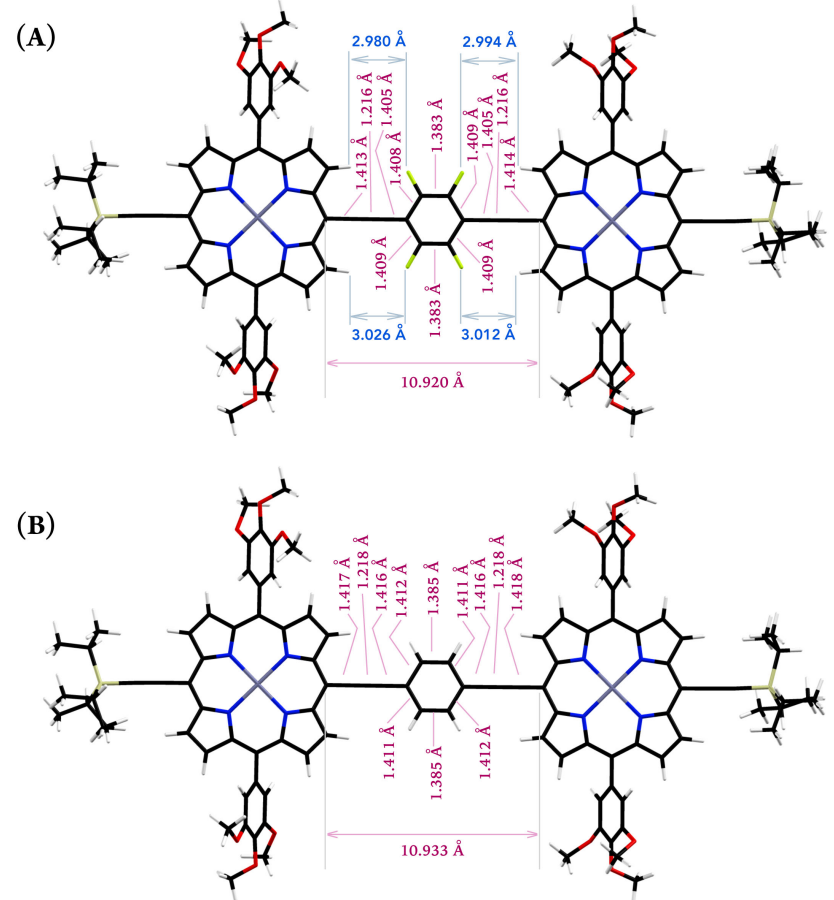

Figure S12. Geometry-optimized structures for 1 (A) and 2 (B) produced by DFT calculations at the B3LYP-D3(BJ) at the 6-311G(d) level for zinc and the $6-31 \mathrm{G}(\mathrm{d})$ for other atoms. The $\mathrm{C}-\mathrm{C}$ bond lengths of the arylene-ethynylene linkages are marked. Cartesian coordinates are listed in Table S5. 

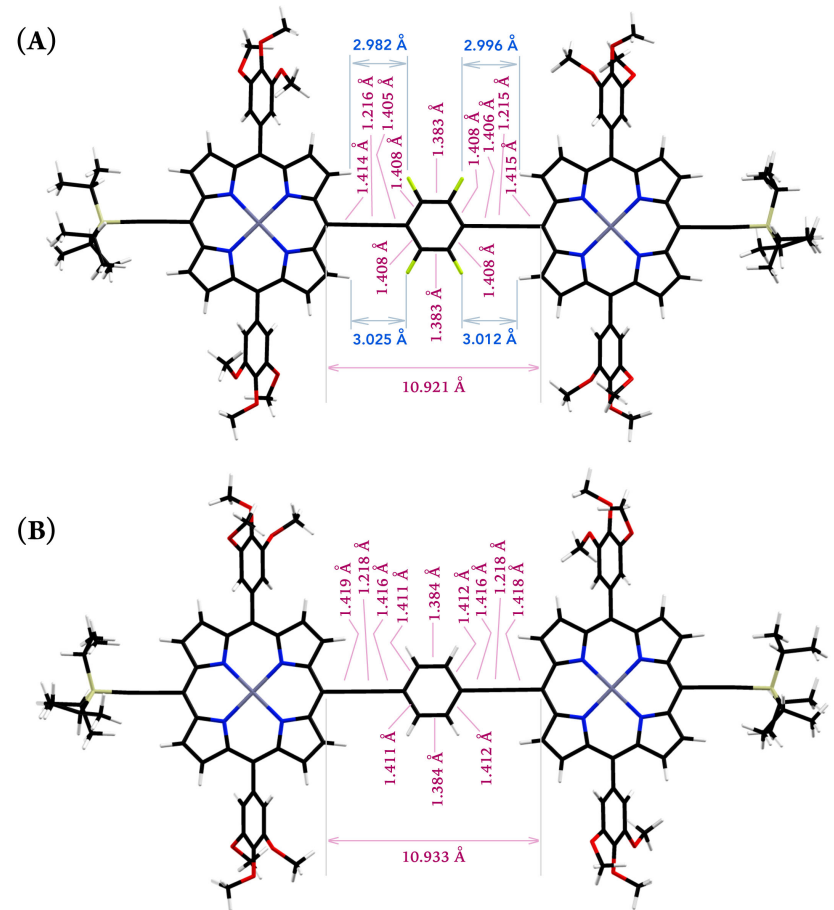

Figure S13. Geometry-optimized structures for 1 (A) and 2 (B) produced by DFT calculations at the B3LYP-D3(BJ) at the 6-31G(d,p) level. The $\mathrm{C}-\mathrm{C}$ bond lengths of the arylene-ethynylene linkages are marked. Cartesian coordinates are listed in Table S6.

To interpret the experimental observations, the quantum theory of atoms in molecules (QTAIM) analysis may be a powerful method. This analytical method is straightforward to evaluate static structures, but its exception is dynamic systems. For instance, the topological electron density analysis found neither bond path nor bond critical point for each edge-facing pairs of the porphyrin $\beta$-protons and fluorine atoms of the optimized geometry of $\mathbf{1}$ at the 6-31G(d,p) level (Figure S14A), indicating the absence of bonded interactions, such as the $\mathrm{C}-\mathrm{F} \cdots \mathrm{H}-\mathrm{C}$ "hydrogen bond" in this geometry. The QTAIM analysis for approximately $3.0 \AA$ of the $\mathrm{F} \cdots \mathrm{H}$ separations of $\mathbf{1}$ is consistent with the view that the $\mathrm{C}-\mathrm{F} \cdots \mathrm{H}-\mathrm{C}$ interaction is shorter than $2.9 \AA$. This result is contradictory to all of the experimental observations. To circumvent the drawback of the QTAIM method, we here assume the doubly bent conformation of the ethynylene linkages as one of the possible non-equilibrium geometries, which is obtained as the optimized geometry at the primitive level (B3LYP-D3(BJ)/3-21G). The non-equilibrium geometry adopts the proximal F $\cdots H$ locations with approximately $2.32 \AA$, for which bond paths indicate bonded interactions (Figure S14C). The topological descriptors at the bond critical points (BCPs) are ranged in the comparable order of the premise of hydrogen bonds, $\rho_{\mathrm{BCP}} \approx 10^{-2} \mathrm{e} \mathrm{au}^{-3}, \nabla^{2} \rho_{\mathrm{BCP}}>0$ e $\mathrm{au}^{-5}$, and $\mathrm{H}_{\mathrm{BCP}}>0$ au. ${ }^{\mathrm{S} 11, \mathrm{~S} 12}$ However, this local minimum at the 3-21G level of the B3LYP-D3(BJ) calculations is unstable by $117 \mathrm{~kJ} \mathrm{~mol}^{-1}$ compared to the local minimum at the 6-31G(d,p) level (compared at the 6-311G(d,p) level), probably because of the very large bent angles with $174.9^{\circ}$ and $172.8^{\circ}$ at the $s p$ carbons. Additionally, the crystal structure of the analogous porphyrin adopt the stretched form of the ethynylene-linkage similarly to the local minimum at the 6$31 \mathrm{G}(\mathrm{d}, \mathrm{p})$ level. Therefore, the local minimum at the $3-21 \mathrm{G}$ level seems not to be really reliable. Nevertheless, the ethynylene-linkages of 1 adopted bent form both in the optimized geometries at the 3- 
$21 \mathrm{G}$ and $6-31 \mathrm{G}(\mathrm{d}, \mathrm{p})$. Then, we here assume a reliable bent form. Bending the $s p$ carbons to $175.2^{\circ}$ and $174.0^{\circ}$ of the bent angles destabilizes the optimized geometry at the $6-31 \mathrm{G}(\mathrm{d}, \mathrm{p})$ level $\left(179.8^{\circ}\right.$ and $\left.179.8^{\circ}\right)$ only by $6.3 \mathrm{~kJ} \mathrm{~mol}^{-1}$ (compared at the $6-311 \mathrm{G}(\mathrm{d}, \mathrm{p})$ level). The topological descriptors becomes insignificant depending on the $\mathrm{F} \cdots \mathrm{H}$ separations (Figure 5 in the main text).

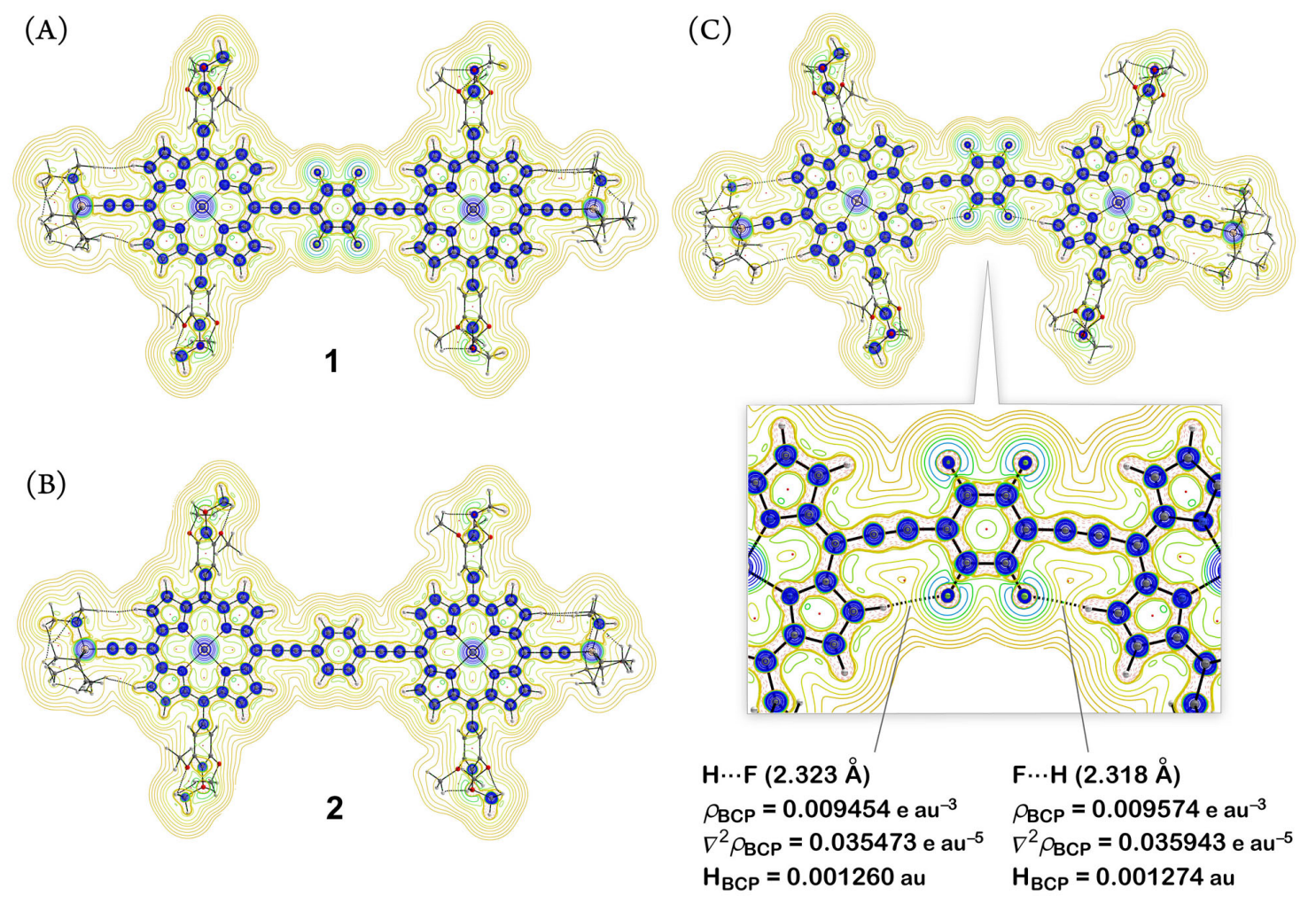

Figure 14. Contour maps of Laplacian of the electron density $\left(\nabla^{2} \rho_{\mathrm{BCP}}\right)$ of $1(\mathrm{~A})$ and $\mathbf{2}(\mathrm{B})$ overlaid with the bond paths based on the QTAIM analysis for the optimized geometries produced by the B3LYP-D3(BJ)/6-31G(d,p) functional. The bond paths on contour map of $\nabla^{2} \rho_{\mathrm{BCP}}$ of the non-equilibrium geometry of $\mathbf{1}$ and the topological descriptors at the bond critical point of the $\mathrm{C}-\mathrm{F} \cdots \mathrm{H}-\mathrm{C}$ interaction $(\mathrm{C})$. Contour lines are drawn at the same color scale.

Due to the calculation cost, we principally employed the B3LYP functional in this study. The aromaticity of the central tetrafluorobenzene ring of $\mathbf{1}$ with the benzene ring of $\mathbf{2}$ were compared by computing nucleus-independent chemical shift, $\mathrm{NICS}(1)_{z z}$, i.e., the total isotropic shielding tensor at $1 \AA$ of the out-of-plane displacement from the aromatic plane circumventing the effect of the $\sigma$-electrons (Figure S15). ${ }^{\mathrm{S} 13, \mathrm{~S} 14}$ The more negative NICS(1) $z z$ value of -9.0887 for the bridging tetrafluorobenzene ring of 1 than -8.4545 for the bridging benzene ring of $\mathbf{2}$ indicated somewhat greater aromaticity of the tetrafluorobenzene ring of $\mathbf{1}$ than the benzene ring of $\mathbf{2}$. However, the HOMO-LUMO gap of $\mathbf{1}$ was nearly identical of 2. Due to the inductive effect of the fluorine, HOMO and LUMO of 1 lowered compared to those of 2 (Figure S16). Small difference in the HOMO-LUMO gap and Frontier molecular orbitals rationalized the subtle difference of the longer edge of the $\mathrm{Q}$ band (Figure 3 in the main text) and the time constant of the torsional relaxation (Table S2), respectively. Based on the DFT study, the tetrafluorophenylene linkage has only marginal impact on the primary $\pi$-conjugated structure of 1 compared to 2 . 

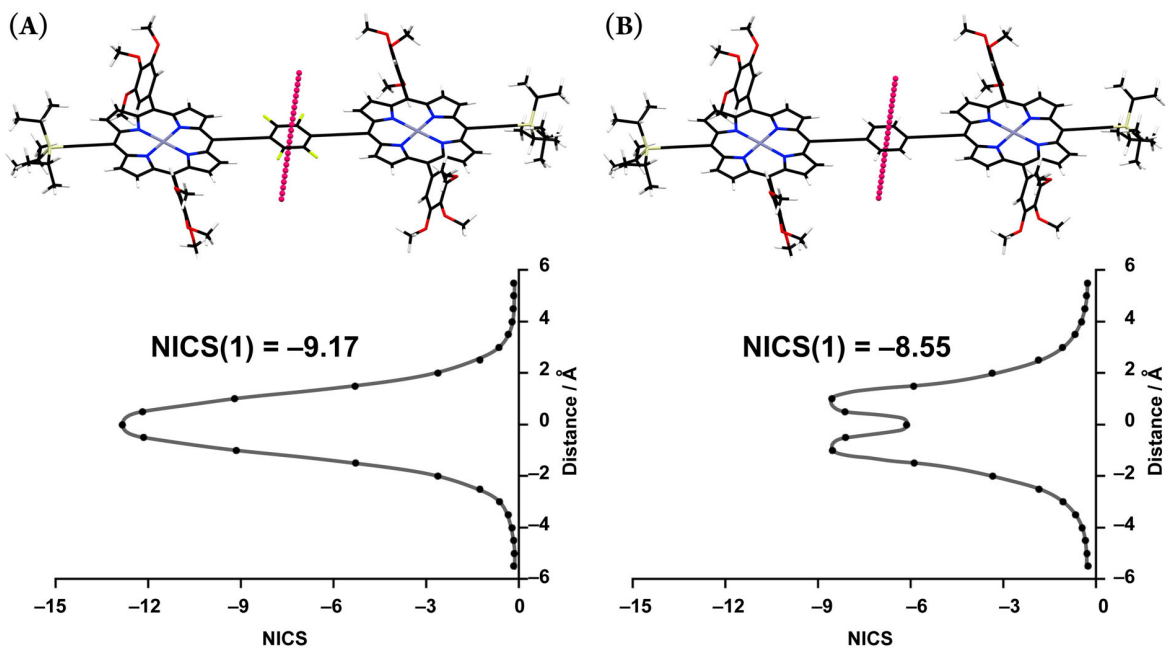

Figure S15. NICS plot for 1 (A) and 2 (B) produced by DFT calculations at the B3LYP/6-31G(d) level. The geometry-optimized structures with the ghost elements, Bq, for NICS calculations (top).

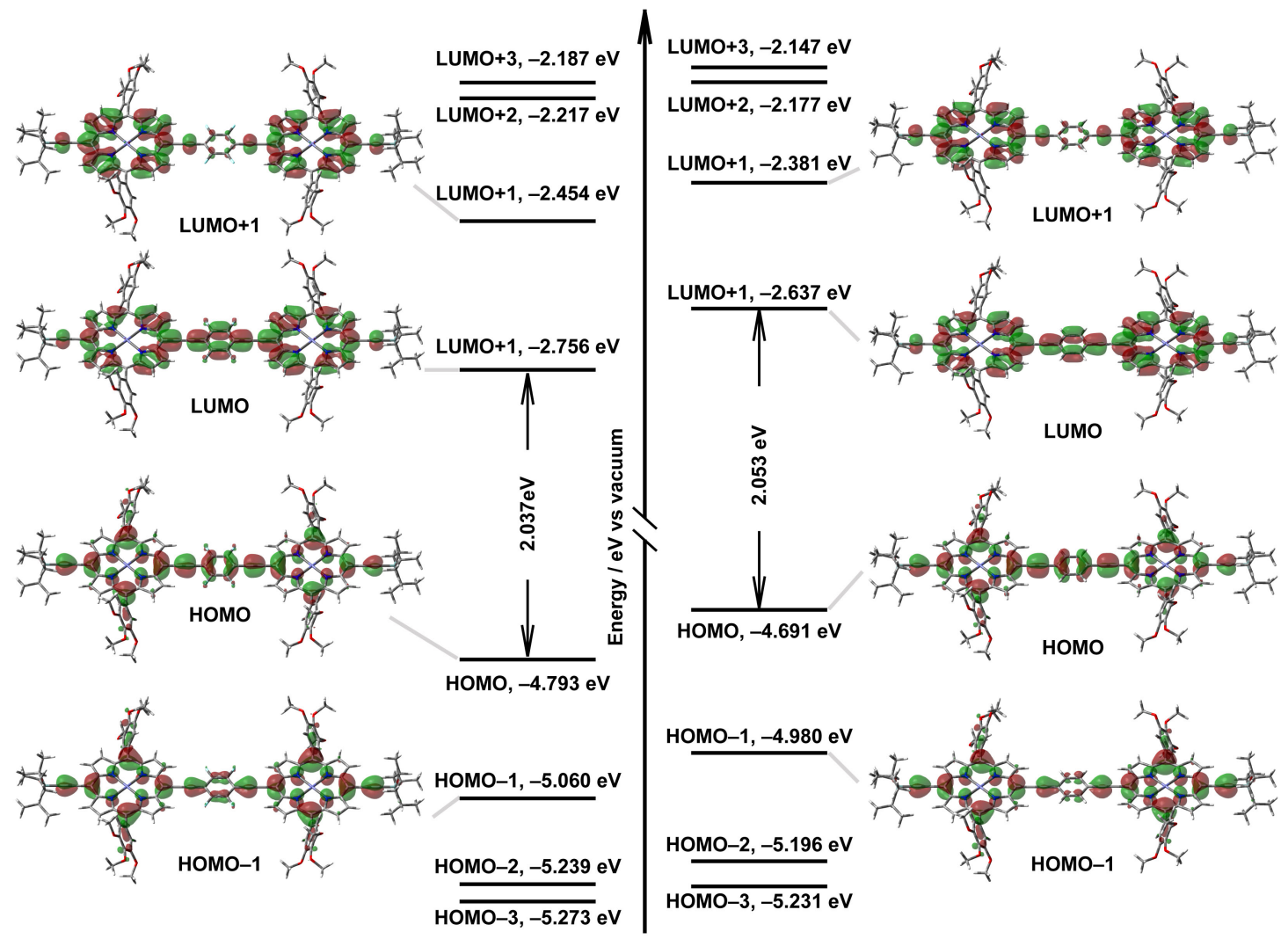

Figure S16. Frontier molecular orbitals and the energy level diagrams of 1 (left) and $\mathbf{2}$ (right) produced by TD-DFT calculations at the 6-311G(d) level for zinc and the 6-31G(d) level for other atoms based on the optimized geometries generated by the B3LYPD3(BJ) functional.

The inductive effect of fluorine atoms affected the electrostatic potential surfaces of the aromatic rings. Electrostatic potential maps delineated the positively polarized surface of the tetrafluorobenzene ring 
of 1 irrespective of the torsional conformation, while the surfaces of the porphyrin rings were negatively polarized (Figure S17A-S17B). On the other hand, all the electron-rich aromatic surfaces of 2 were negatively polarized (Figure S17C-S17D). The electrostatic properties of the aromatic surface could contribute to the self-aggregation behaviors and the solvation behaviors with aromatic solvents, as described in the main text and below.

(A) $1\left(\theta=\phi=0^{\circ}\right)$
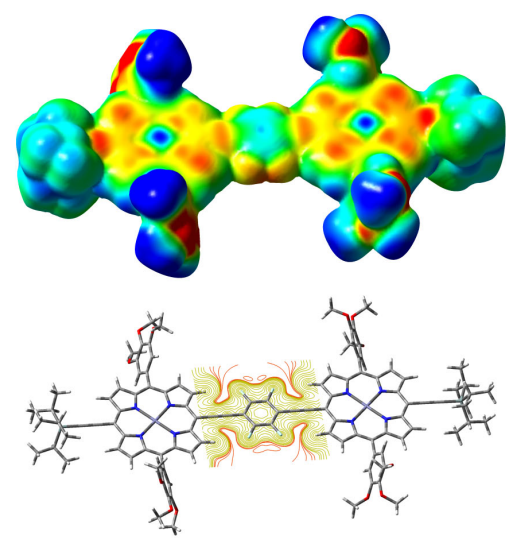

(B) $1\left(\theta=\phi=90^{\circ}\right)$
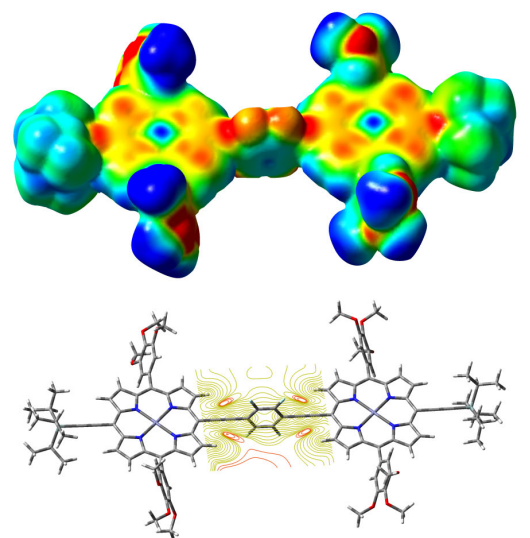

(C) $2\left(\theta=\phi=0^{\circ}\right)$
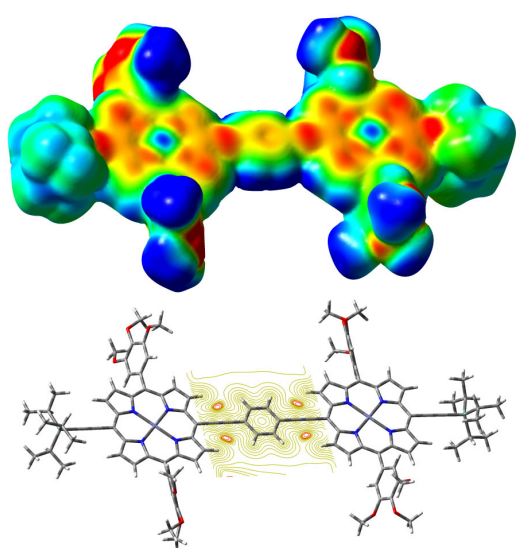

(D) $2\left(\theta=\phi=90^{\circ}\right)$
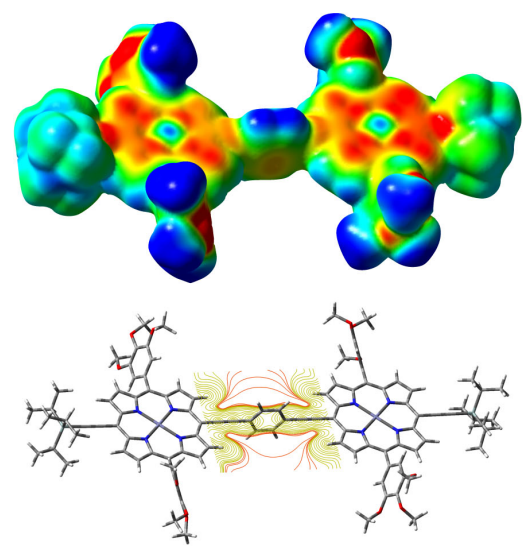

$+31.5$

Electrostatic Potential / kJ mol

Figure S17. Electrostatic potential maps and contour views of $\mathbf{1}$ at $\theta=\phi=0^{\circ}(\mathrm{A})$ and at $\theta=\phi=90^{\circ}(\mathrm{B})$, and 2 at $\theta=\phi=0^{\circ}(\mathrm{C})$ and at $\theta=\phi=90^{\circ}(\mathrm{B})$ produced from DFT calculations at the B3LYP/6-31G(d) level. The geometry-optimized structures are at $\theta=\phi=$ $0^{\circ}$, and the most disfavored structures are at $\theta=\phi=90^{\circ}(\theta$ and $\phi$ are defined in Figure 4$)$. The electrostatic potential surfaces were mapped onto 0.0004 atomic units isovalue. The red and blue surfaces correspond to a region of negative and positive electrostatic potentials, respectively, and all the potential values are displayed in the same range. 


\section{Self-Aggregation Behaviors}

\subsection{Aggregation behaviors in toluene}

As aforementioned, 1 obeyed the Beer's law up to $9.1 \times 10^{-6} \mathrm{M}$ in toluene (Figure S1). At the relatively high concentrations above $0.3 \mathrm{mM}$, on the other hand, 1 was prone to show $\pi$-stacking interactions. ${ }^{1} \mathrm{H}$ NMR spectra of 1 in toluene- $d_{5}$ showed gradual broadening of the signals in the absence of pyridine- $d 5$. These observations contrast with the doublet signals found in the presence of pyridine- $d_{5}$ (Figure 2 and S23). The edge and F-facing $\beta$-protons of the porphyrin rings (blue and green circles, respectively, in Figure $\mathrm{S} 18 \mathrm{~A}$ ) significantly broadened as increasing the concentration, unlike the aryl-shielded $\beta$-protons (yellow signals). The selective broadening of the $\beta$-protons suggested that the edge and $\mathrm{F}$-facing $\beta$-protons are partially shielded by the double-strand formation, for which the $\pi$-stacked configuration would be confined by the interdigitated bulky side-chains, as illustrated in Figure S18. The broad signals suggested that the $\pi$ stacking double-strand configuration involves thermal fluctuation along with the long axis. Thermal dissociation sharpened the considerably broad signals as elevating temperature from $298 \mathrm{~K}$ (Figure S18B). It is remarkable that the self-aggregation prevailed strong solvation with toluene (vide infra).

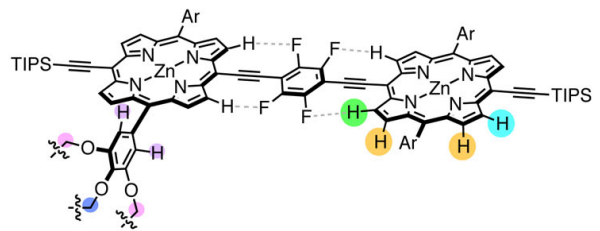

(A)

$[1] / \mathrm{mM}$

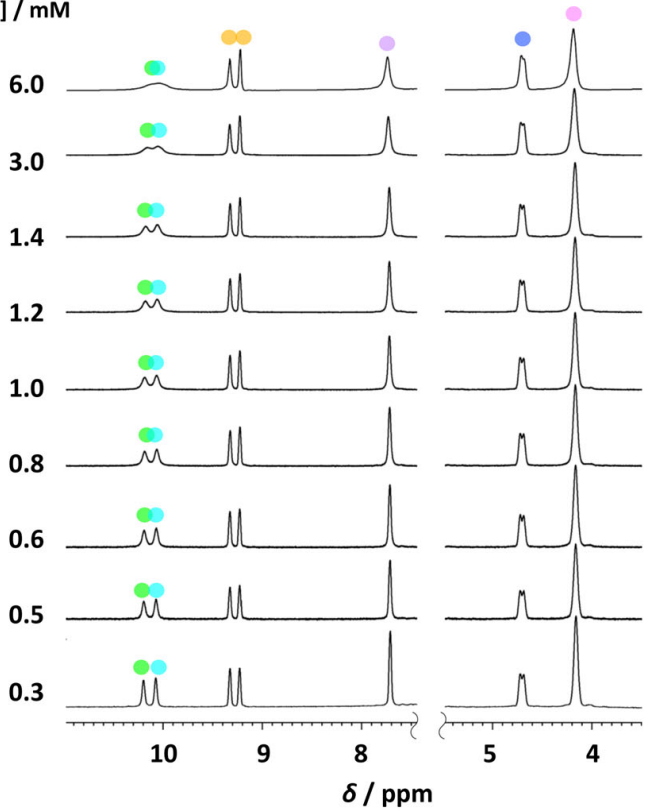

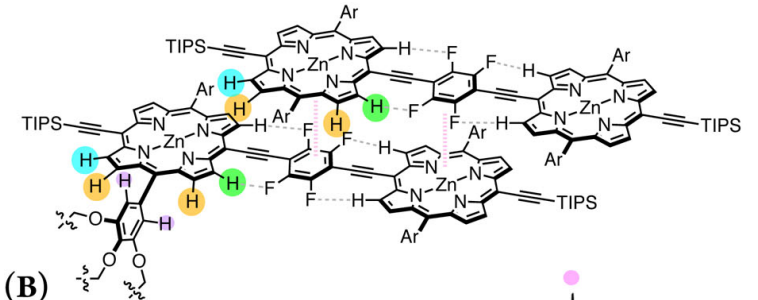

(B)

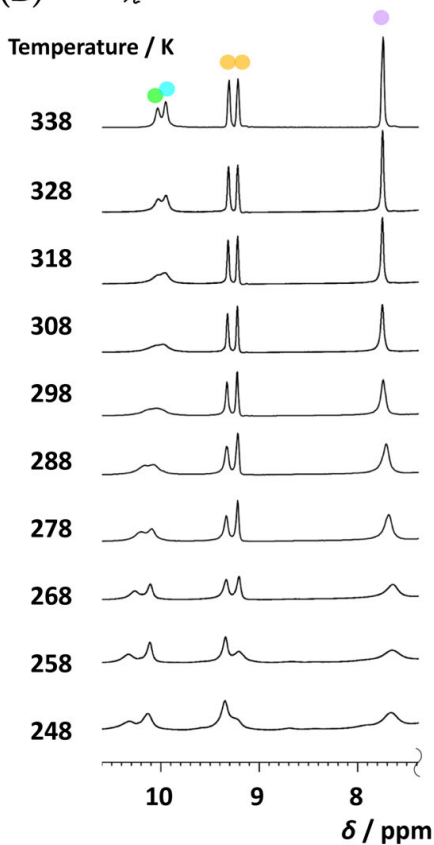

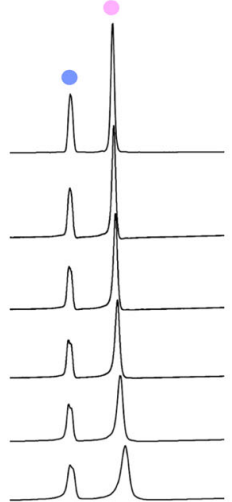
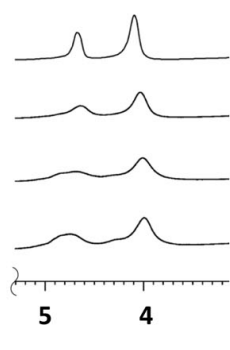

Figure S18. ${ }^{1} \mathrm{H}$ NMR spectra $(600 \mathrm{MHz})$ of 1 at various concentrations from $0.3 \mathrm{mM}$ to $6.0 \mathrm{mM}$ (lower to upper) at $298 \mathrm{~K}$ in toluene$d_{8}$ (A). Temperature-variable ${ }^{1} \mathrm{H}$ NMR spectra of 1 at $6.0 \mathrm{mM}$ in toluene- $d_{8}$ upon elevating temperature from 248 to $338 \mathrm{~K}$ (lower to upper) (B). 


\subsection{Quadrupolar interaction of tetrafluorophenylene unit with aromatic rings}

In cyclohexane, $\mathbf{1}$ predominantly formed a double-strand, as described in the main text. The supplementary results are shown below. Upon increasing the concentration, the middle Soret band at $453 \mathrm{~nm}$ showed large hypochromism (Figure 6), indicating that the parallel arrangement of the transition dipole moments increases the degree of the forbidden electronic transition, and concurrently bathochromic shift of the longer Soret band from 483 to $489 \mathrm{~nm}$ indicates the head-to-tail arrangement of the transition dipole moments results in constructive exciton coupling (Figure S19). ${ }^{\mathrm{S1}, \mathrm{S} 2, \mathrm{~S} 15}$ Spectral nature suggests that the double-strand adopted a slipped-cofacial $\pi$-stacked configuration with the interdigitated alkyl side-chains, supporting the structure of (1) $)_{2}$ observed in ${ }^{1} \mathrm{H}$ NMR. The similar reversible spectral changes were found for variabletemperature electronic absorption spectra of $\mathbf{1}$, that displayed small hypsochromic shift together with gradual increase of the middle Soret band, suggesting thermal dissociation of the double-strand (Figure 6). Assuming temperature-independent enthalpy change $(\Delta H)$ and entropy change $(\Delta S)$ according to van't Hoff equation ( $-R T \ln K_{\mathrm{a}}=\Delta H-T \Delta S$, wherein $R$ refers gas constant), $\Delta H$ and $\Delta S$ were determined as $\Delta H=-$ $98.1 \pm 5.4 \mathrm{~kJ} \mathrm{~mol}^{-1}$ and $\Delta S=-0.20 \pm 0.02 \mathrm{~kJ} \mathrm{~mol}^{-1}\left(K_{\mathrm{a}}=\left[(\mathbf{1})_{2}\right] /[\mathbf{1}]^{2}=4.3 \times 10^{6} \mathrm{M}^{-1}\right.$ at $\left.298 \mathrm{~K}\right)$ from the temperature-variable experiment at $1.06 \times 10^{-5} \mathrm{M}$. The concentration variation of 1 at $298 \mathrm{~K}$ also indicated the aggregation behavior. The global fitting analysis estimated $K_{\mathrm{a}}=(4.30 \pm 0.18) \times 10^{6} \mathrm{M}^{-1}$ (Figure S20A and S20B), in excellent agreement with the estimated $\Delta H$ and $\Delta S$ values. In the same way, $\Delta H$ and $\Delta S$ for the double-strand formation of 2 were determined as $\Delta H=-77.0 \pm 9.0 \mathrm{~kJ} \mathrm{~mol}^{-1}$ and $\Delta S=-0.16 \pm 0.03 \mathrm{~kJ}$ $\mathrm{mol}^{-1}\left(K_{\mathrm{a}}=\left[(2)_{2}\right] /[2]^{2}=7.2 \times 10^{4} \mathrm{M}^{-1}\right.$ at $\left.298 \mathrm{~K}\right)$ from the experiment at $6.19 \times 10^{-6} \mathrm{M}$ (Figure 6). This was well corroborated by the concentration variation of 2 at $298 \mathrm{~K}$, in which $K_{\mathrm{a}}=(7.22 \pm 0.08) \times 10^{4} \mathrm{M}^{-1}$ (Figure S20C and S20D).

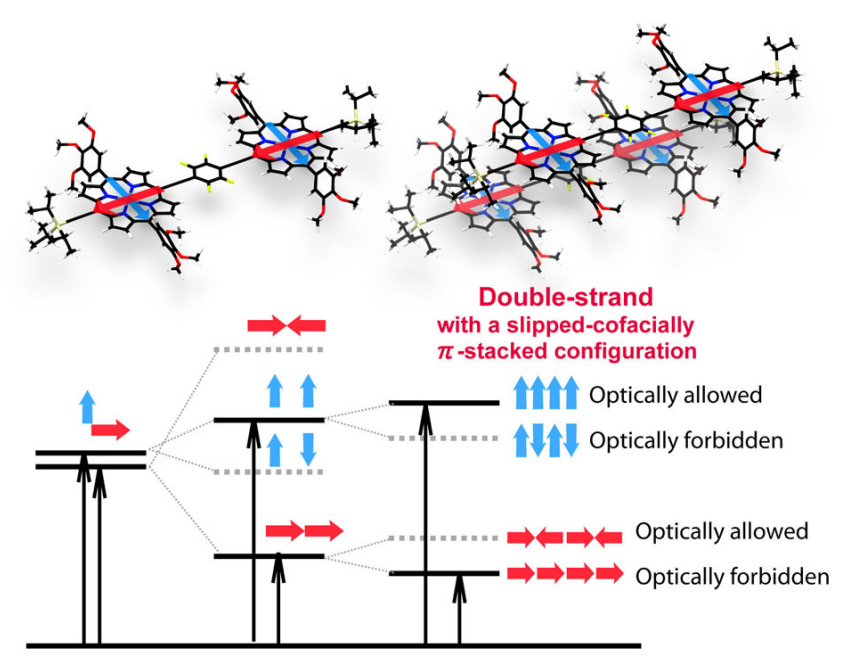

Figure S19. Schematic energy diagram of the double-strand with the successively slipped-cofacial $\pi$-stacking configuration. 

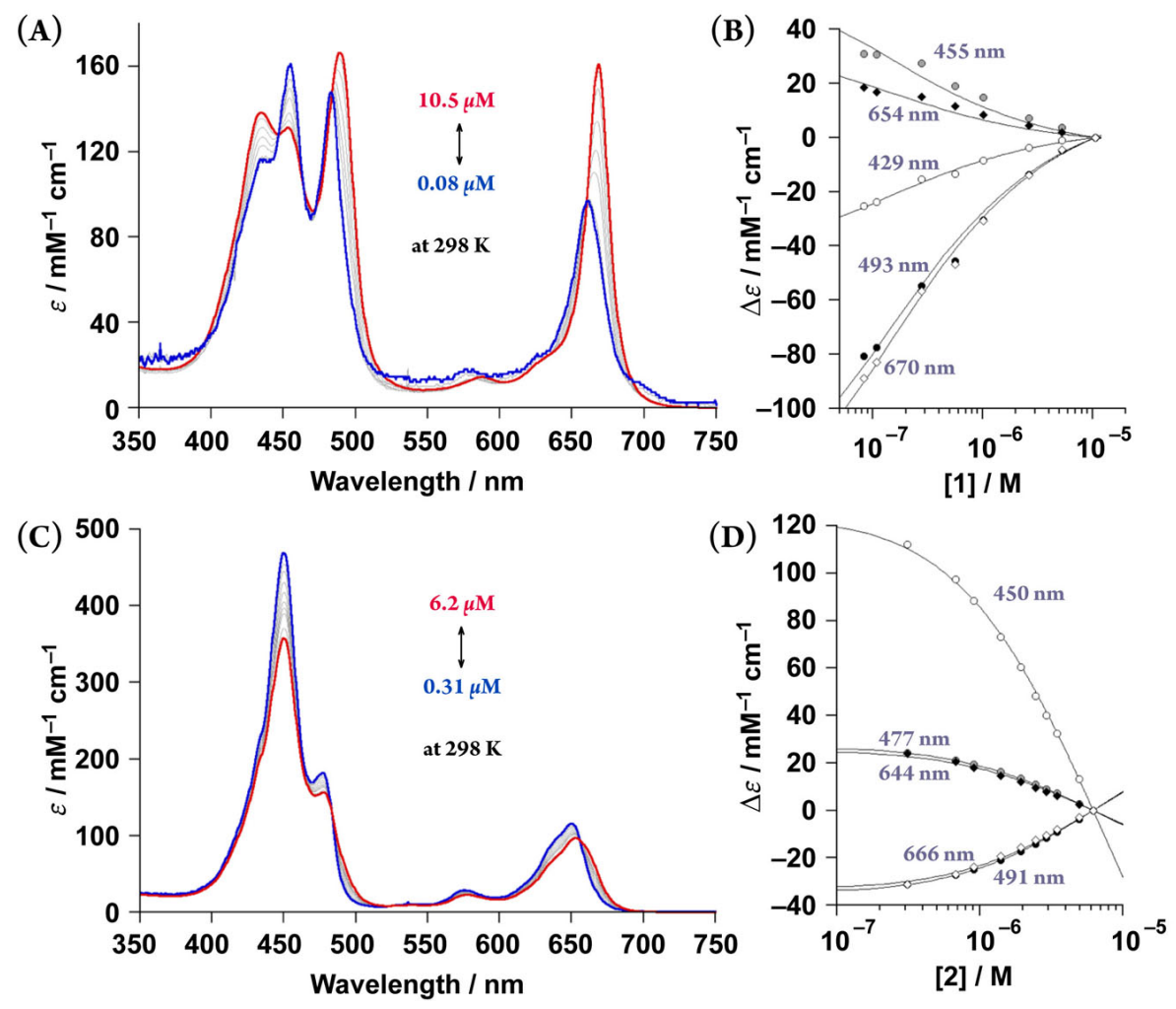

Figure S20. Spectral evolution of electronic absorption spectra of 1 upon increasing concentration from $0.08 \mu \mathrm{M}$ to $10.6 \mu \mathrm{M}$ (blue to pink) at $298 \mathrm{~K}$ in cyclohexane (A) and the global fitting isotherms assuming $K_{\mathrm{a}}=(4.30 \pm 0.18) \times 10^{6} \mathrm{M}^{-1}$ for the double-strand formation (B). Similar observation for 2 upon increasing concentration from $0.31 \mu \mathrm{M}$ to $6.2 \mu \mathrm{M}$ (blue to pink) at $298 \mathrm{~K}$ in cyclohexane (C), and the global fitting isotherms assuming $K_{\mathrm{a}}=(7.22 \pm 0.08) \times 10^{4} \mathrm{M}^{-1}$ for the double-strand formation (D).

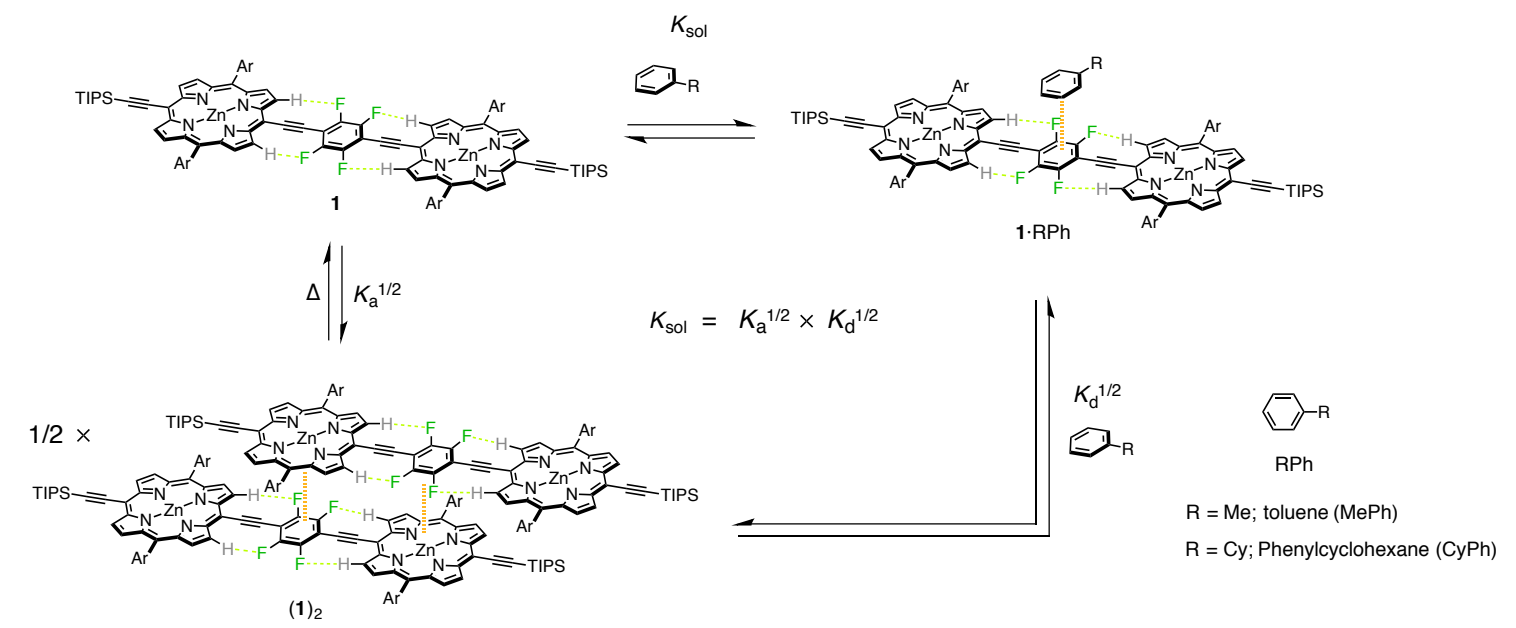

Scheme S3. Closed thermodynamic cycle for the dimer formation of $1\left(K_{\mathrm{a}}=\left[(\mathbf{1})_{2}\right] /[\mathbf{1}]^{2}\right)$, the quadrupolar interaction of arene with 1 $\left(K_{\mathrm{sol}}=[\mathbf{1} \cdot \mathrm{RPh}] /[\mathbf{1}][\mathrm{RPh}]\right)$, and the competitive dissociation of the dimer with arene $\left(K_{\mathrm{d}}=[\mathbf{1} \cdot \mathrm{RPh}]^{2} /\left[(\mathbf{1})_{2}\right][\mathrm{RPh}]^{2}\right)$.

The quadrupolar interactions between the tetrafluorobenzene ring of $\mathbf{1}$ and benzene ring of aromatic solvent molecules were verified by titration experiments in cyclohexane. Although the double-strand 
formation hampered direct estimation of the binding strength of toluene $(\mathrm{MePh})$ and phenylcyclohexane $(\mathrm{CyPh})$ to $1\left(K_{\mathrm{sol}}=[\mathbf{1} \cdot \mathrm{RPh}] /[\mathbf{1}][\mathrm{RPh}]\right)$, the competitive titration experiments with excess amount of $\mathrm{MePh}$ and $\mathrm{CyPh}$ enabled estimating the magnitude of $K_{\text {sol }}$ based on the closed thermodynamic cycle (Scheme S3). The spectral evolution of 1 upon the addition of $\mathrm{MePh}$ and $\mathrm{CyPh}$ showed several pseudo-isosbestic points, suggesting apparently two-state equilibrium (Figure S21), where the spectral shapes were closely reminiscent of the equilibrium between double-strand and single-strand (Figure 6 and S20A). Assuming a one-step dissociation equilibrium model, the dissociation constants were determined as $K_{\mathrm{d}}=$ $[\mathbf{1} \cdot \mathrm{MePh}]^{2} /\left[(\mathbf{1})_{2}\right][\mathrm{MePh}]^{2}=3.09 \times 10^{-5} \mathrm{M}^{-1}$ for $\mathrm{MePh}$, and $K_{\mathrm{d}}=[\mathbf{1} \cdot \mathrm{CyPh}]^{2} /\left[(\mathbf{1})_{2}\right][\mathrm{CyPh}]^{2}=1.84 \times 10^{-5} \mathrm{M}^{-}$ ${ }^{1}$ for $\mathrm{CyPh}$. Therefore, the binding strengths of $\mathrm{MePh}$ and $\mathrm{CyPh}$ to 1 were estimated as $K_{\text {sol }}=K_{\mathrm{a}}{ }^{1 / 2} \times K_{\mathrm{d}}{ }^{1 / 2}$ $=11.5 \mathrm{M}^{-1}$ and $K_{\text {sol }}=8.9 \mathrm{M}^{-1}$, respectively. The values were in a comparable order with our previous observations for the quadrupolar interaction between the porphyrin ring and hexafluorobenzene in cyclohexane, ${ }^{\mathrm{S} 16}$ in line with the observations that $\mathbf{1}$ obeyed the Beer's law at the very dilute concentrations in toluene (Figure S1, vide supra).
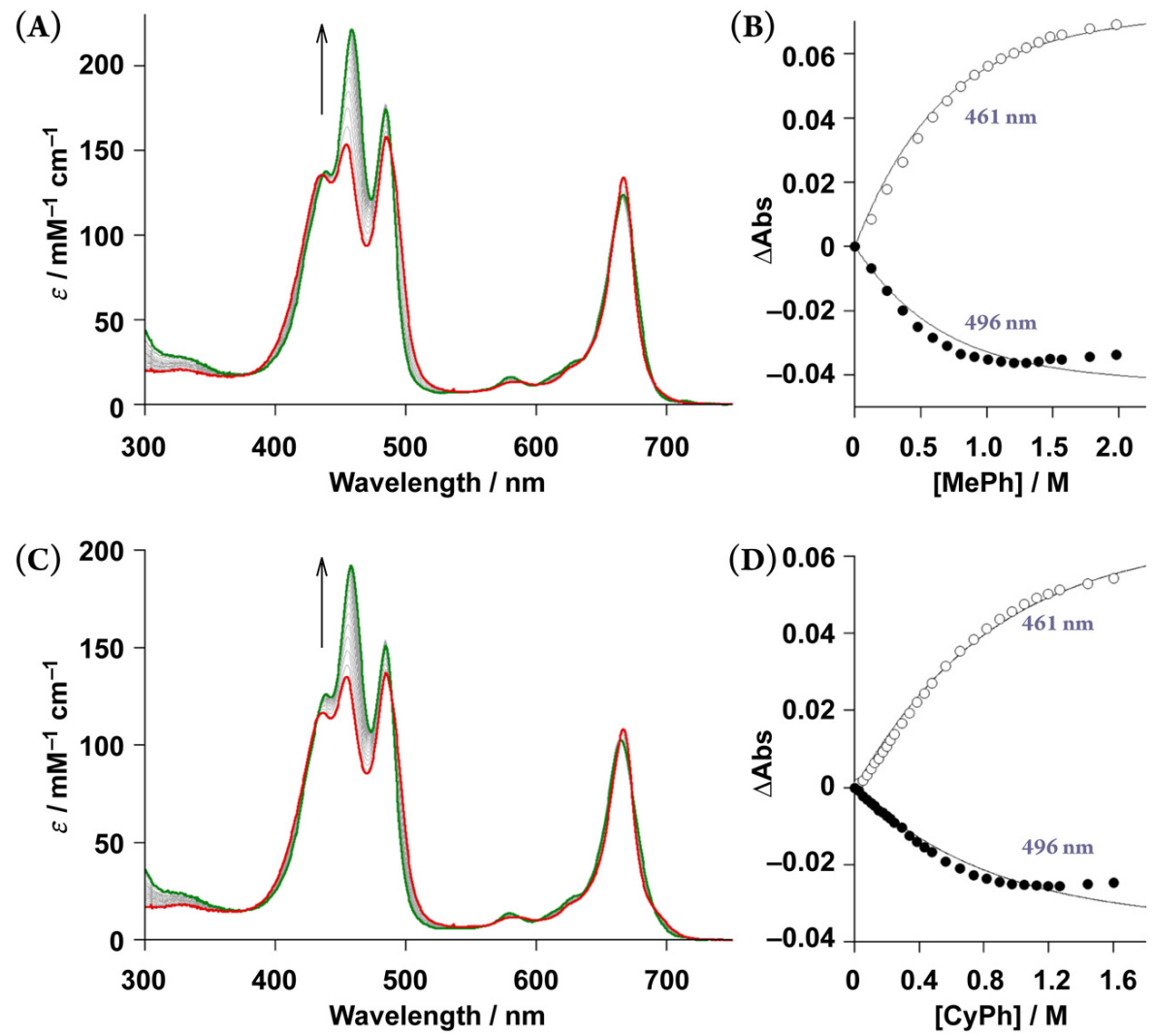

Figure S21. Spectrometric titration of $(1)_{2}\left([1]_{0}=7.8 \times 10^{-7} \mathrm{M}\right.$, dilution up to $6.2 \times 10^{-7} \mathrm{M}$ ) with toluene (up to $2.0 \mathrm{mM}$, red to green) at $298 \mathrm{~K}$ in cyclohexane (A), and global fitting analysis of the titration isotherms assuming a one-step double-strand dissociation with $K_{\mathrm{d}}=(3.09 \pm 0.41) \times 10^{-5} \mathrm{M}^{-1}(\mathrm{~B})$. Spectrometric titration of $(\mathbf{1})_{2}\left([1]_{0}=7.8 \times 10^{-7} \mathrm{M}\right.$, dilution up to $\left.6.2 \times 10^{-7} \mathrm{M}\right)$ with phenylcyclohexane (up to $1.6 \mathrm{M}$, red to green) at $298 \mathrm{~K}$ in cyclohexane (C), and global fitting analysis of the titration isotherms assuming a one-step double-strand dissociation with $K_{\mathrm{d}}=(1.84 \pm 0.20) \times 10^{-5} \mathrm{M}^{-1}(\mathrm{D})$. 
On the other hand, 2 scarcely formed the double-strand $\left(K_{\mathrm{a}}=7.45 \times 10^{4} \mathrm{M}^{-1}\right)$ under the dilute conditions in cyclohexane (the concentration of the double-strand was estimated to be $0.25 \times 10^{-7} \mathrm{M}$ at $6.3 \times 10^{-7} \mathrm{M}$ of total concentration), and the predominant monomeric form allowed direct estimation of the binding strength of $\mathrm{MePh}$ and $\mathrm{CyPh}$ to $2\left(K_{\mathrm{sol}}=[\mathbf{2} \cdot \mathrm{RPh}] /[\mathbf{2}][\mathrm{RPh}]\right)$ based on the simple titration experiments (Scheme S4). Titration experiments of 2 with $\mathrm{MePh}$ and $\mathrm{CyPh}$ in cyclohexane resulted in small bathochromic shift due to small solvent polarity effect (Figure S22). The spectral changes through several isosbestic points suggested two-state equilibrium. The titration isotherms were likely analyzed assuming the 1:1 2. $\mathrm{RPh}$ complex formation. The binding strength of $\mathrm{MePh}$ and $\mathrm{CyPh}$ to 2 was estimated as $K_{\text {sol }}=$ $0.79 \mathrm{M}^{-1}$ and $K_{\text {sol }}=0.49 \mathrm{M}^{-1}$, respectively.

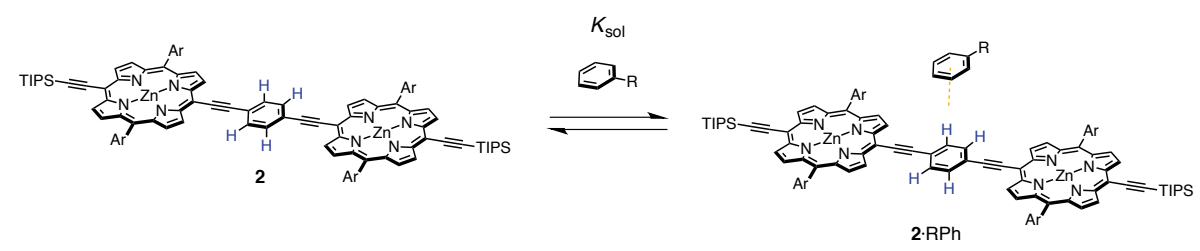

Scheme S4. The 1:1 complex formation of $2\left(K_{\text {sol }}=[2 \cdot R P h] /[2][R P h]\right)$.
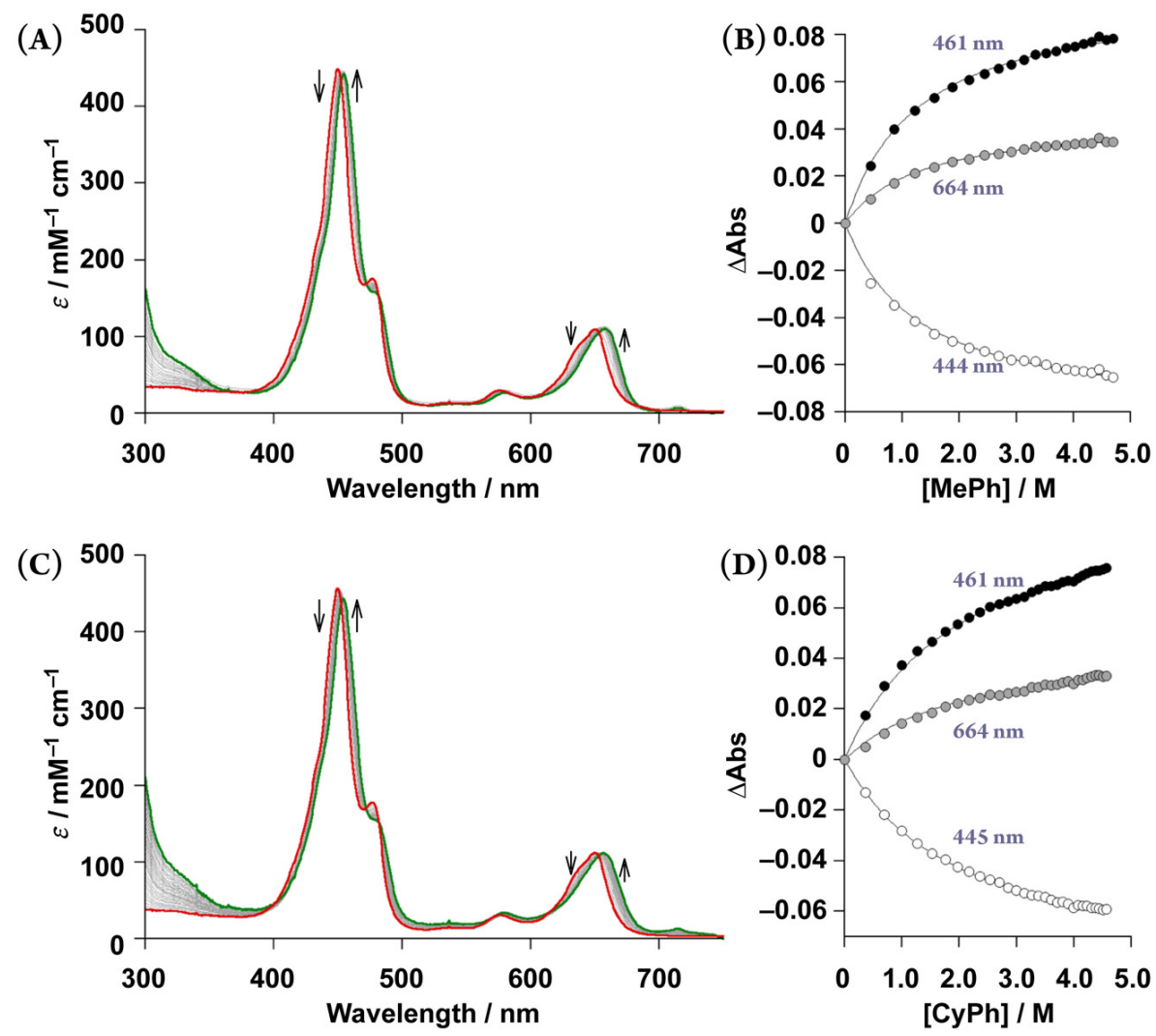

Figure S22. Spectrometric titration of $2\left([2]_{0}=6.3 \times 10^{-7} \mathrm{M}\right.$, dilution up to $3.2 \times 10^{-7} \mathrm{M}$ ) with toluene (from $0 \mathrm{M}$ up to $4.7 \mathrm{M}$, red to green) at $298 \mathrm{~K}$ in cyclohexane (A), and global fitting analysis of the titration isotherms assuming a 1:1 2·MePh complex formation with $K_{\text {sol }}=0.785 \pm 0.02 \mathrm{M}^{-1}$ (B). Spectrometric titration of $2\left([2]_{0}=6.3 \times 10^{-7} \mathrm{M}\right.$, dilution up to $\left.2.1 \times 10^{-7} \mathrm{M}\right)$ with phenylcyclohexane (from $0 \mathrm{M}$ up to $4.6 \mathrm{M}$, red to green) at $298 \mathrm{~K}$ in cyclohexane $(\mathrm{C})$, and global fitting analysis of the titration isotherms assuming a $1: 1$ 2. CyPh complex formation with $K_{\text {sol }}=0.488 \pm 0.01 \mathrm{M}^{-1}$ (D). 
The estimated thermodynamic parameters are listed in Table S3, although it is difficult to directly compare the absolute magnitudes of the $K_{\text {sol }}$ values because of the difference in numerical precisions depending on the estimation methods. Nevertheless, the $K_{\text {sol }}$ values for $\mathbf{1}$ are approximately one order of magnitude greater than those of $\mathbf{2}$, indicating that the aromatic solvents possess higher affinity to $\mathbf{1}$ rather than 2 though the quadrupolar interaction. The results supports the existence of the quadrupolar interaction between the tetrafluorobenzene ring of $\mathbf{1}$ and benzene ring of aromatic solvent molecules. The observations accounted for the enhanced viscosity effect on the photoexcited conformational relaxation behaviors of 1 .

Table S3. Binding constants (at $298 \mathrm{~K}$ ) and thermodynamic parameters of $\mathbf{1}$ and $\mathbf{2}$ in cyclohexane.

\begin{tabular}{|c|c|c|c|c|c|}
\hline & \multicolumn{2}{|c|}{$K_{\text {sol }} / \mathrm{M}^{-1}$} & \multicolumn{2}{c|}{$K_{\mathrm{d}} / \mathrm{M}^{-1}$} & $K_{\mathrm{a}} / \mathrm{M}^{-1}$ \\
& $\mathrm{MePh}$ & $\mathrm{CyPh}$ & $\mathrm{MePh}$ & $\mathrm{CyPh}$ & $\left(\Delta H, \Delta S / \mathrm{kJ} \mathrm{mol}{ }^{-1}\right)$ \\
\cline { 2 - 6 } & $11.5 \pm 0.88$ & $8.9 \pm 0.62$ & $(3.09 \pm 0.41) \times 10^{-5}$ & $(1.84 \pm 0.20) \times 10^{-5}$ & $(4.30 \pm 0.18) \times 10^{6}$ \\
& & & & & $-98.1 \pm 5.4,-0.20 \pm 0.02)$ \\
\hline 2 & $0.785 \pm 0.02$ & $0.488 \pm 0.01$ & - & $(7.22 \pm 0.08) \times 10^{4}$ \\
& & & & & $(-74.8 \pm 8.7,-0.16 \pm 0.03)$ \\
\hline
\end{tabular}

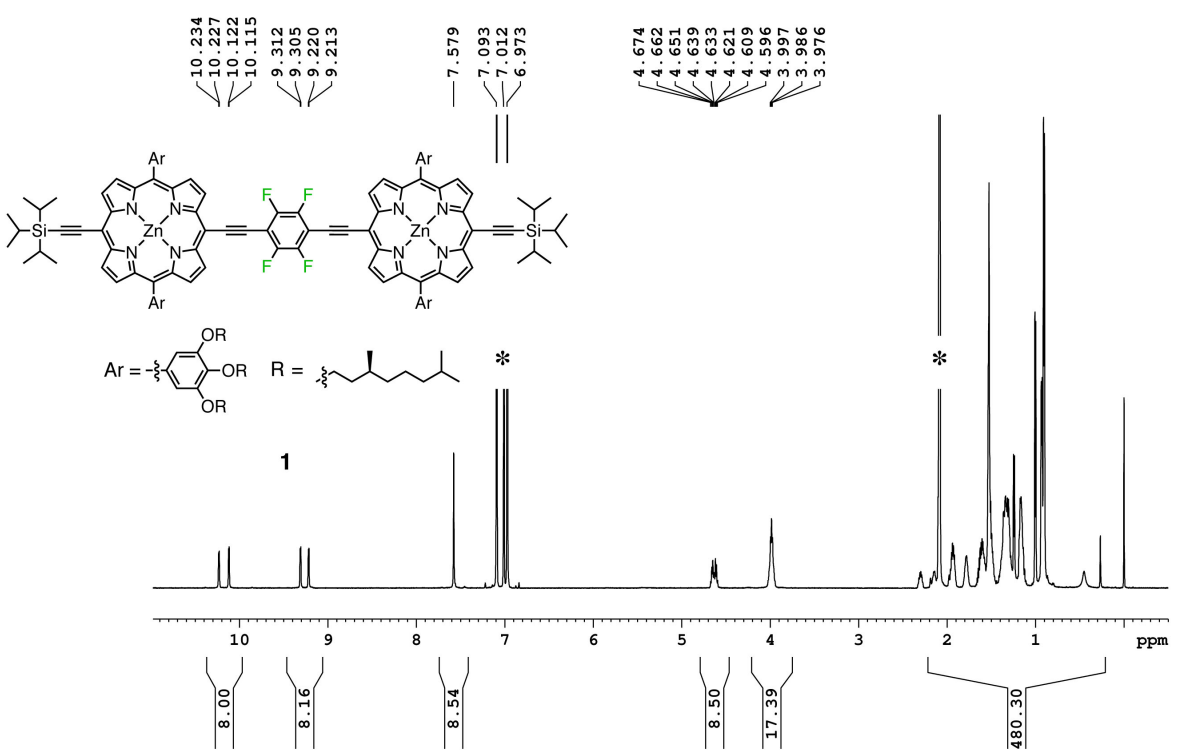

Figure S23. ${ }^{1} \mathrm{H}$ NMR spectrum $(600 \mathrm{MHz})$ of 1 in toluene- $d 8$ with an aliquot of pyridine- $d 5$. Asterisk indicates residual solvent. 


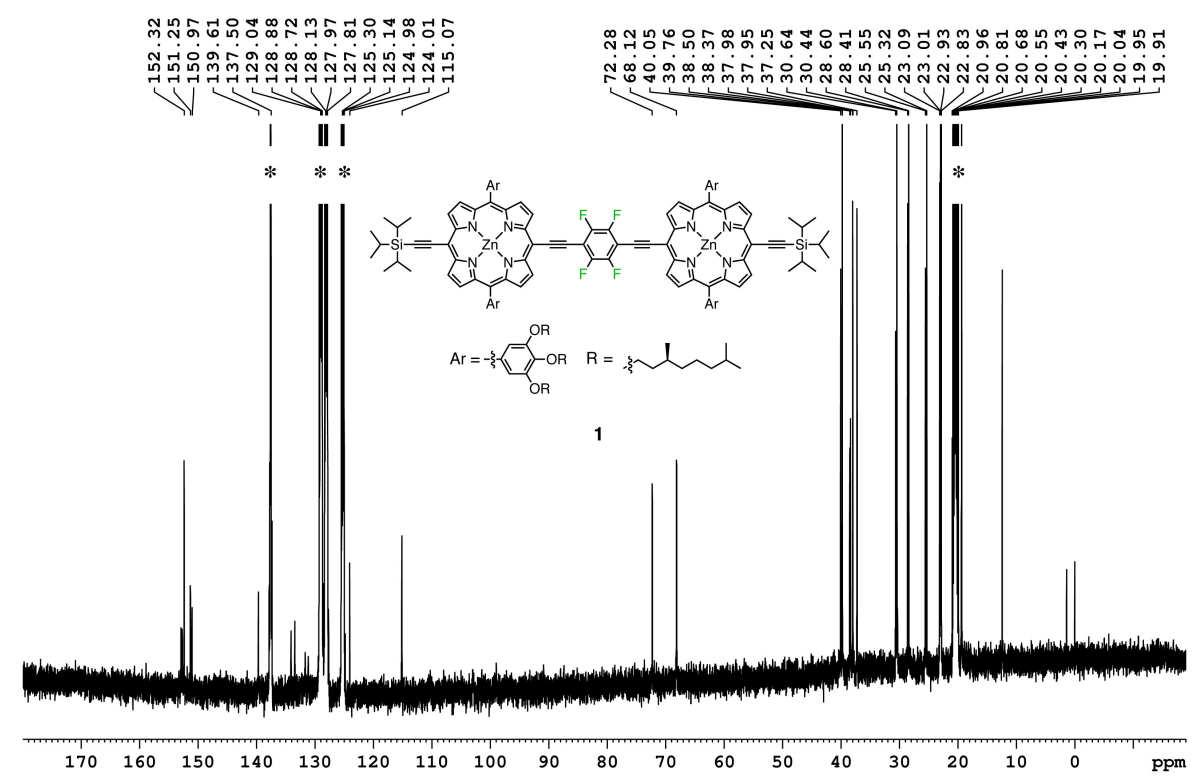

Figure S24. ${ }^{13} \mathrm{C}$ NMR spectrum $(150 \mathrm{MHz})$ of $\mathbf{1}$ in toluene- $d_{8}$. Asterisk indicates solvent.

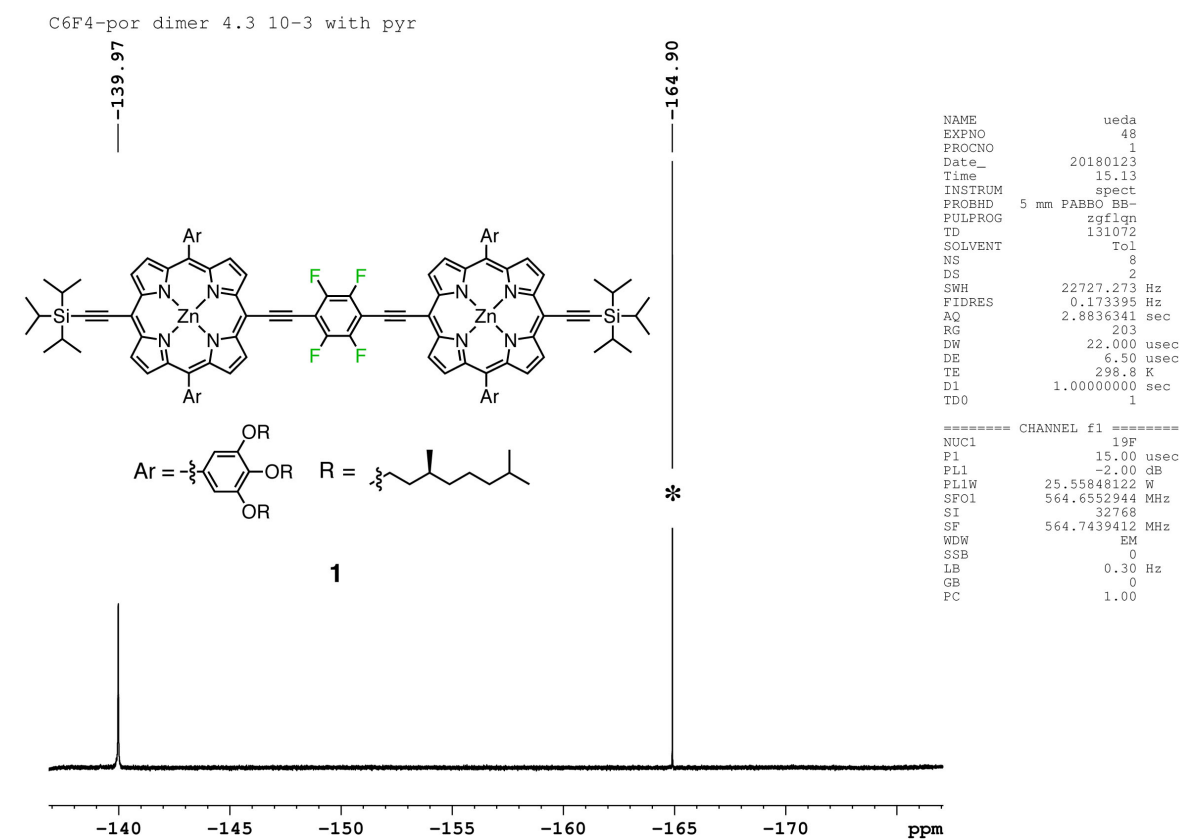

Figure S25. ${ }^{19} \mathrm{~F}$ NMR spectrum $(565 \mathrm{MHz})$ of 1 in toluene- $d_{8}$ with an aliquot of pyridine- $d_{5}$. Asterisk indicates $\mathrm{C}_{6} \mathrm{~F}_{6}$ as the internal standard. 


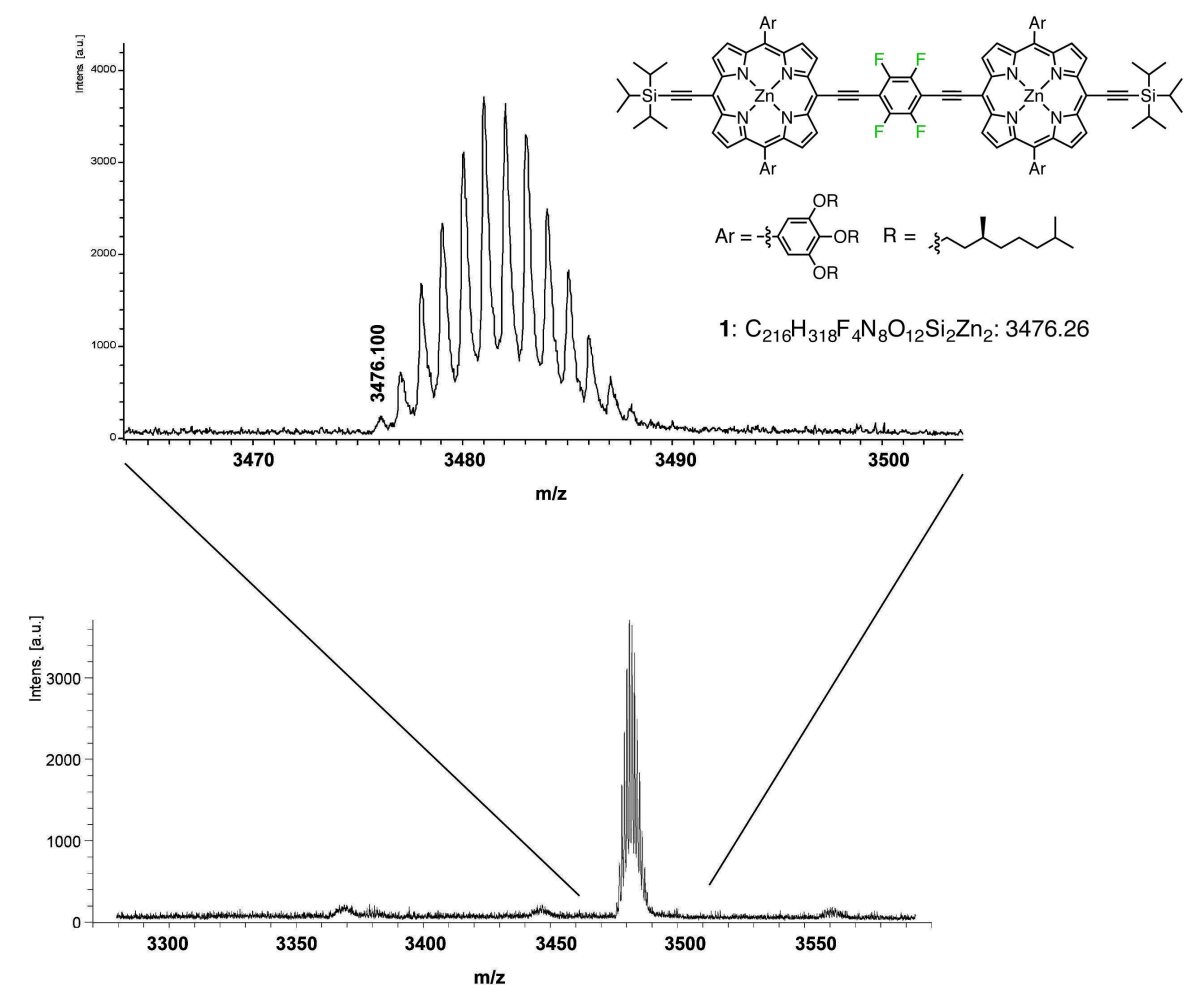

Figure S26. MALDI-TOF MS spectrum of 1.

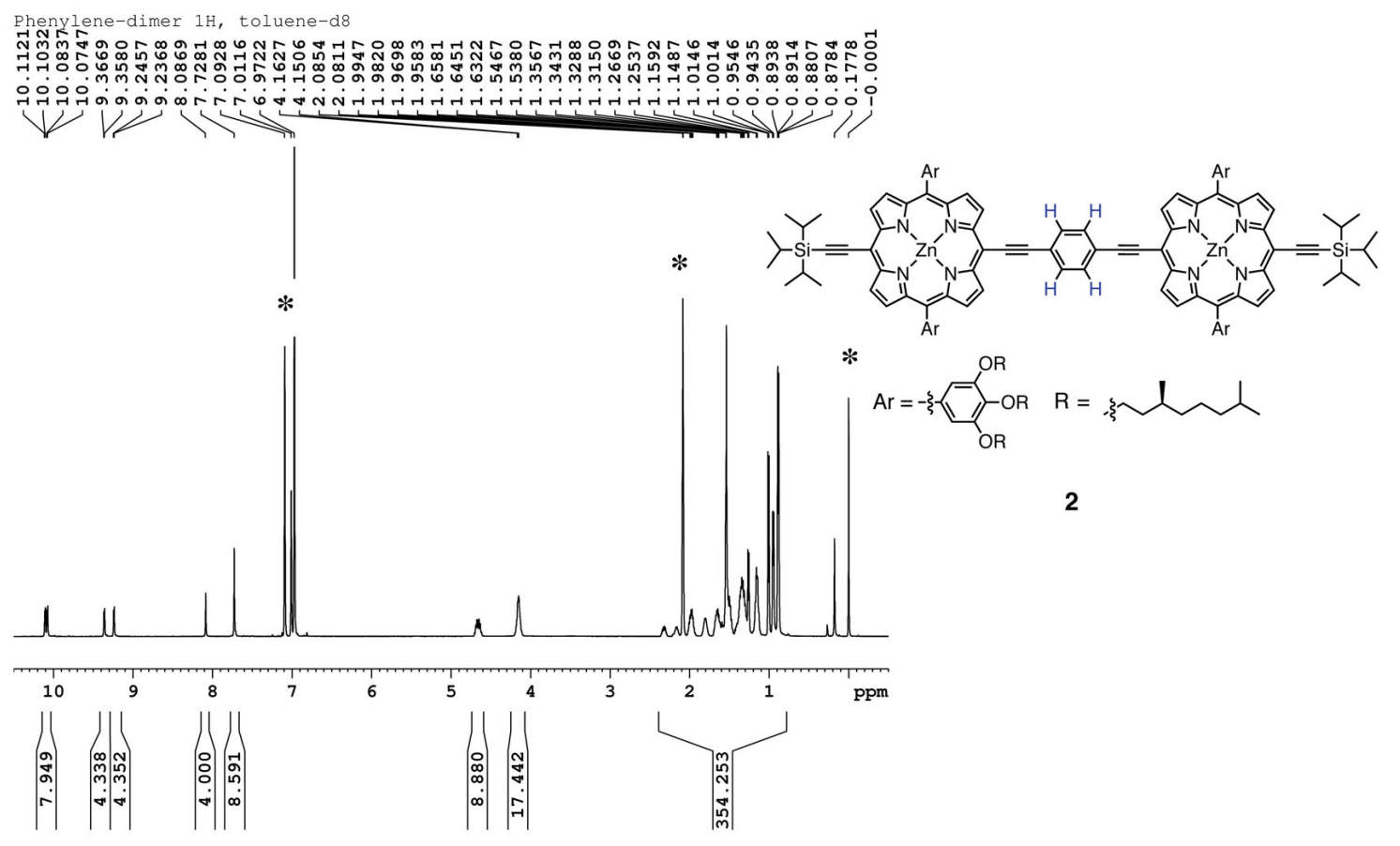

Figure S27. ${ }^{1} \mathrm{H}$ NMR spectrum $(500 \mathrm{MHz})$ of 2 in toluene- $d_{8}$. Asterisk indicates residual solvent and TMS. 

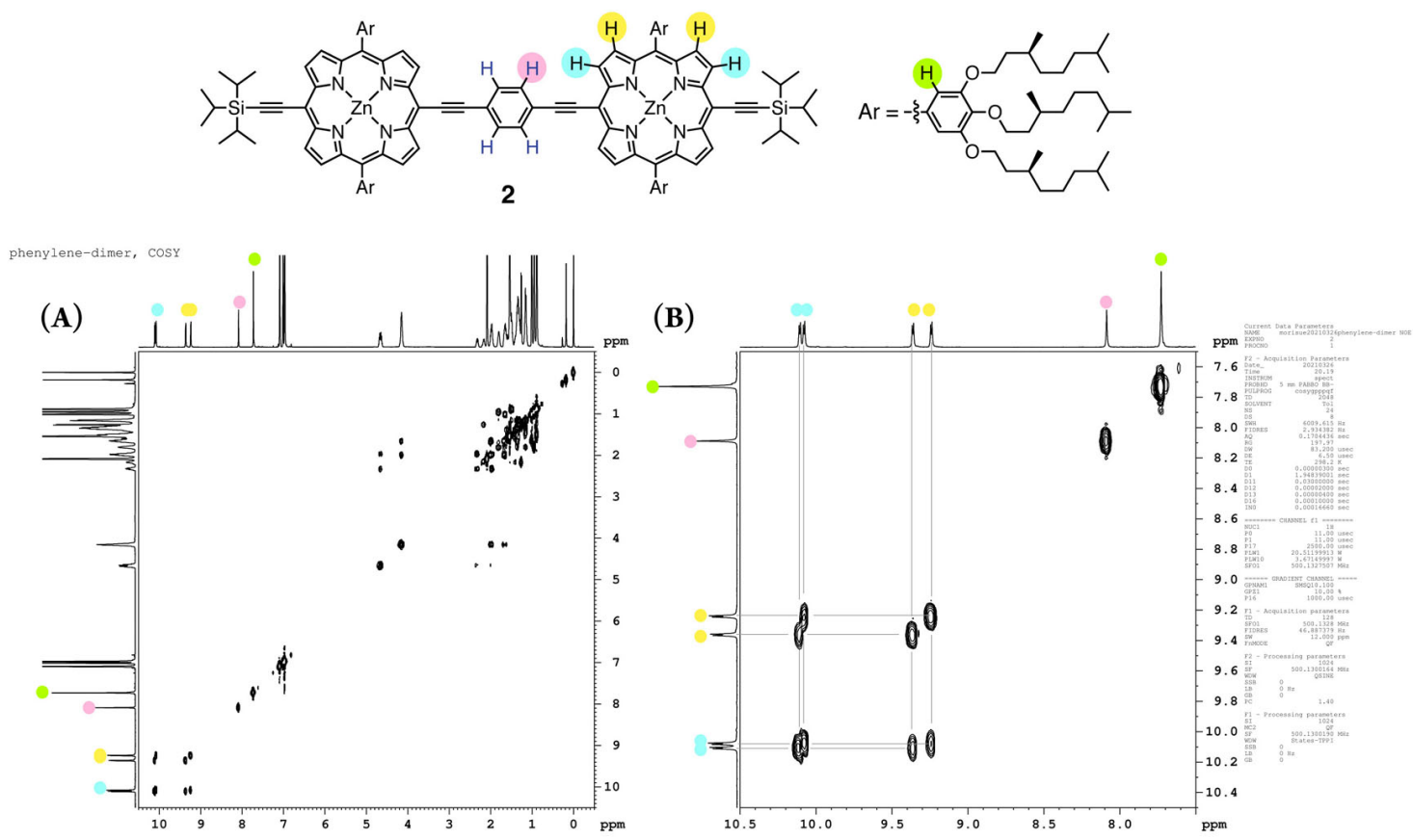

Figure S28. ${ }^{1} \mathrm{H}-{ }^{1} \mathrm{H}$ COSY spectrum $(500 \mathrm{MHz})$ of 2 in toluene- $d_{8}(\mathrm{~A})$, and the aromatic region is magnified (B).
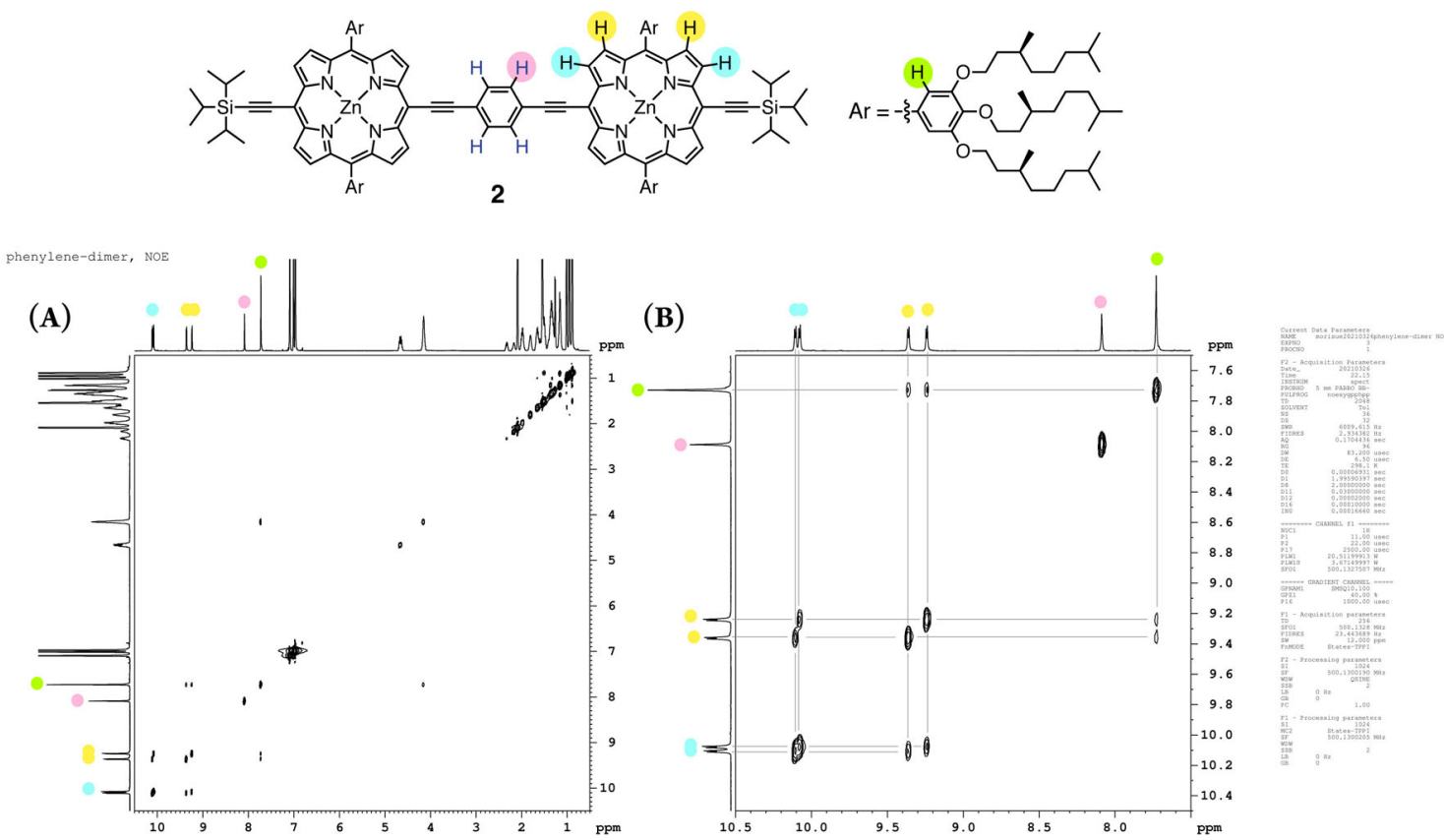

Figure S29. ${ }^{1} \mathrm{H}-{ }^{1} \mathrm{H}$ NOESY spectrum (500 MHz) of 2 in toluene- $d_{8}$ (A), and the aromatic region is magnified (B). 


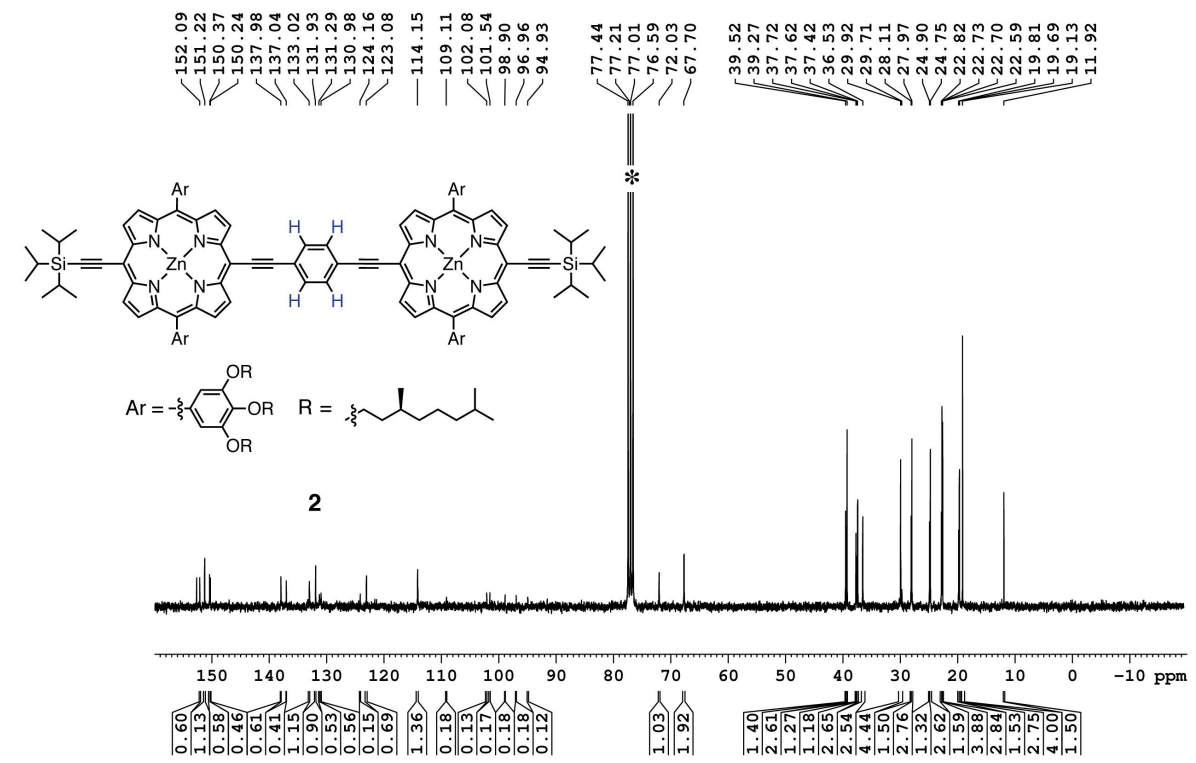

Figure S30. ${ }^{13} \mathrm{C}$ NMR spectrum ( $75 \mathrm{MHz}$ ) of $\mathbf{2}$ in $\mathrm{CDCl}_{3}$. Asterisk indicates solvent.

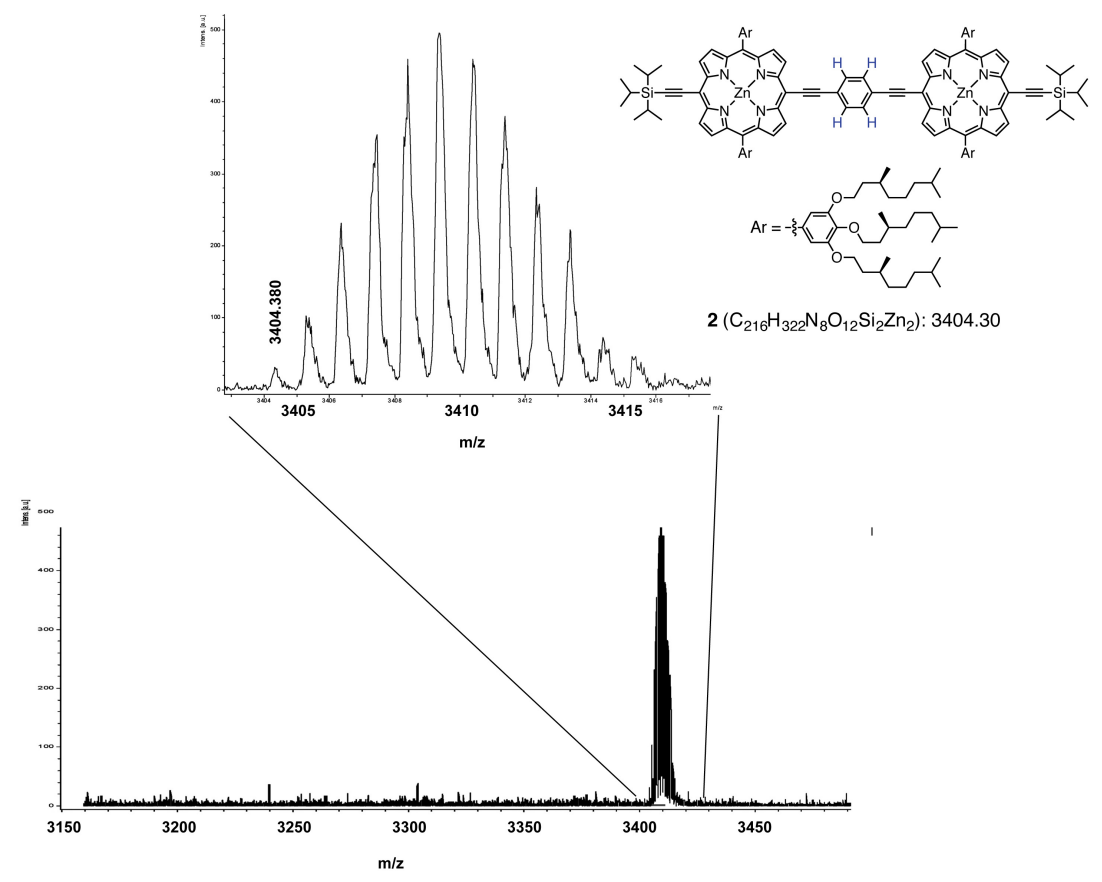

Figure S31. MALDI-TOF MS spectrum of 2. 
Table S4. Cartesian coordinates of the geometry-optimized structures of 1 and 2 obtained from the DFT B3LYP/6-31G(d) calculations. Atom numbers are indicated in the labeled structures of 1 (A) and 2 (B).

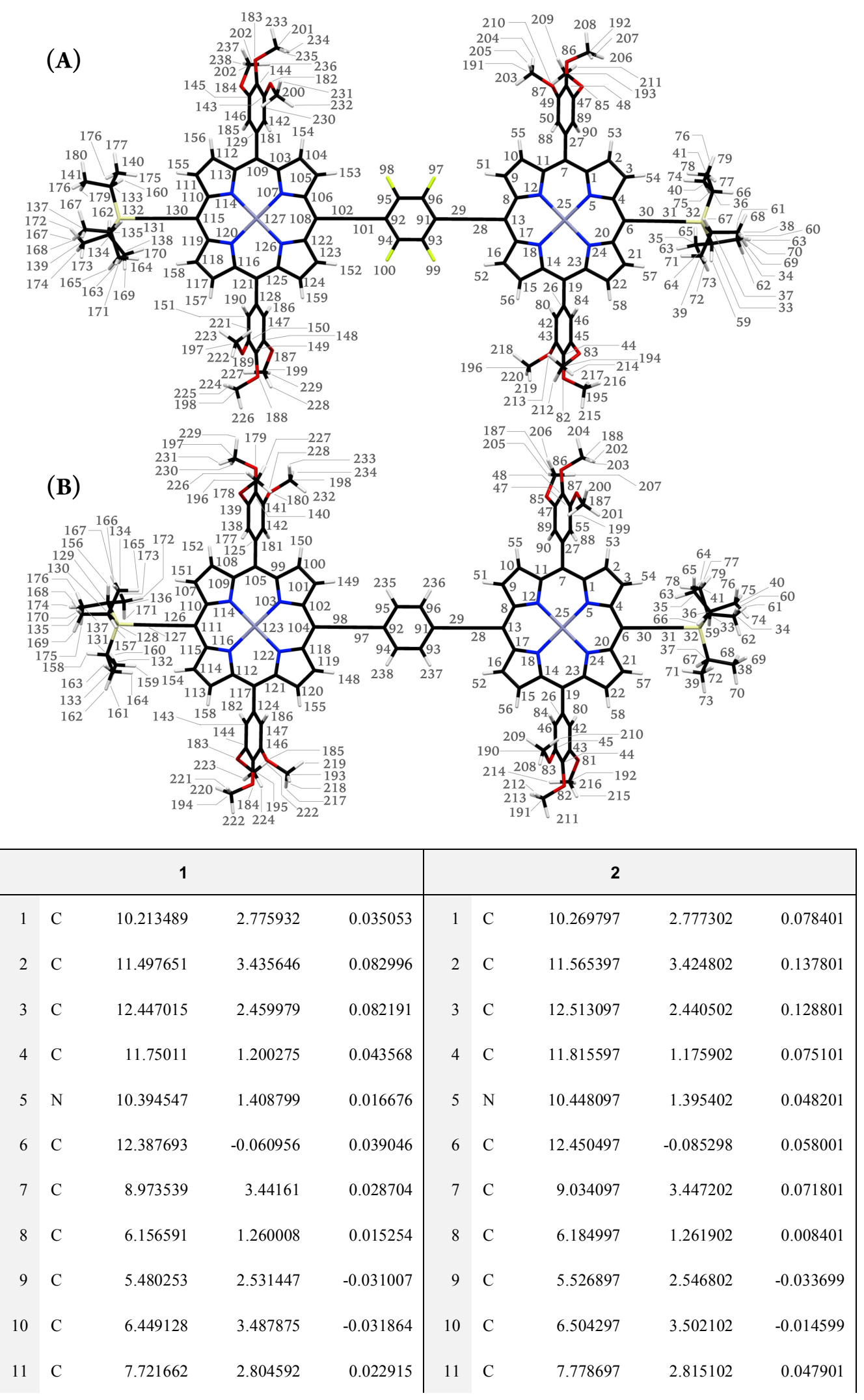




\begin{tabular}{|c|c|c|c|c|c|c|c|c|c|}
\hline 12 & $\mathrm{~N}$ & 7.513097 & 1.439865 & 0.045987 & 12 & $\mathrm{~N}$ & 7.557297 & 1.438702 & 0.054001 \\
\hline 13 & $\mathrm{C}$ & 5.496728 & 0.008959 & 0.023405 & 13 & $\mathrm{C}$ & 5.510997 & 0.018702 & 0.002401 \\
\hline 14 & $\mathrm{C}$ & 7.664354 & -2.831291 & 0.047317 & 14 & $\mathrm{C}$ & 7.694497 & -2.844298 & 0.031301 \\
\hline 15 & $\mathrm{C}$ & 6.37783 & -3.488502 & 0.093211 & 15 & $\mathrm{C}$ & 6.398897 & -3.492698 & 0.064501 \\
\hline 16 & $\mathrm{C}$ & 5.428576 & -2.512724 & 0.081571 & 16 & $\mathrm{C}$ & 5.450397 & -2.508798 & 0.050001 \\
\hline 17 & $\mathrm{C}$ & 6.130966 & -1.255314 & 0.038742 & 17 & $\mathrm{C}$ & 6.147297 & -1.244098 & 0.018301 \\
\hline 18 & $\mathrm{~N}$ & 7.483749 & -1.462602 & 0.019967 & 18 & $\mathrm{~N}$ & 7.514497 & -1.461898 & 0.010801 \\
\hline 19 & $\mathrm{C}$ & 8.902979 & -3.493653 & 0.05063 & 19 & $\mathrm{C}$ & 8.930397 & -3.513598 & 0.039601 \\
\hline 20 & $\mathrm{C}$ & 11.72449 & -1.309209 & 0.037347 & 20 & $\mathrm{C}$ & 11.778597 & -1.327198 & 0.046401 \\
\hline 21 & $\mathrm{C}$ & 12.395831 & -2.582969 & 0.002948 & 21 & $\mathrm{C}$ & 12.438597 & -2.612498 & 0.010501 \\
\hline 22 & $\mathrm{C}$ & 11.426721 & -3.539117 & 0.004127 & 22 & $\mathrm{C}$ & 11.461697 & -3.567998 & 0.006101 \\
\hline 23 & $\mathrm{C}$ & 10.156215 & -2.853292 & 0.04781 & 23 & $\mathrm{C}$ & 10.185597 & -2.881198 & 0.046301 \\
\hline 24 & $\mathrm{~N}$ & 10.364997 & -1.490078 & 0.063351 & 24 & $\mathrm{~N}$ & 10.404997 & -1.505298 & 0.065601 \\
\hline 25 & $\mathrm{Zn}$ & 8.939676 & -0.026086 & 0.036203 & 25 & $\mathrm{Zn}$ & 8.982497 & -0.033398 & 0.043601 \\
\hline 26 & $\mathrm{C}$ & 8.889352 & -4.992784 & 0.055254 & 26 & $\mathrm{C}$ & 8.908797 & -5.014198 & 0.040501 \\
\hline 27 & $\mathrm{C}$ & 8.990331 & 4.940711 & 0.028193 & 27 & $\mathrm{C}$ & 9.057297 & 4.947502 & 0.090901 \\
\hline 28 & $\mathrm{C}$ & 4.079888 & 0.022741 & 0.015104 & 28 & $\mathrm{C}$ & 4.088897 & 0.039802 & -0.020799 \\
\hline 29 & $\mathrm{C}$ & 2.862547 & 0.032555 & 0.006857 & 29 & $\mathrm{C}$ & 2.865697 & 0.056802 & -0.042099 \\
\hline 30 & $\mathrm{C}$ & 13.814536 & -0.077745 & 0.034075 & 30 & $\mathrm{C}$ & 13.878797 & -0.106398 & 0.047601 \\
\hline 31 & $\mathrm{C}$ & 15.0379 & -0.10034 & 0.024811 & 31 & $\mathrm{C}$ & 15.106797 & -0.125298 & 0.029201 \\
\hline 32 & $\mathrm{Si}$ & 16.882972 & -0.145808 & 0.014606 & 32 & $\mathrm{Si}$ & 16.977397 & -0.132298 & -0.006199 \\
\hline 33 & $\mathrm{C}$ & 17.457656 & -1.383054 & -1.341783 & 33 & $\mathrm{C}$ & 17.576497 & -1.269498 & -1.474599 \\
\hline 34 & $\mathrm{C}$ & 18.91405 & -1.141297 & -1.790271 & 34 & $\mathrm{C}$ & 19.002797 & -0.901998 & -1.944599 \\
\hline 35 & $\mathrm{C}$ & 16.523514 & -1.460172 & -2.564921 & 35 & $\mathrm{C}$ & 16.596197 & -1.300098 & -2.667699 \\
\hline 36 & $\mathrm{C}$ & 17.510878 & 1.636266 & -0.305319 & 36 & $\mathrm{C}$ & 17.551197 & 1.714302 & -0.215299 \\
\hline 37 & $\mathrm{C}$ & 17.422269 & -0.735515 & 1.759387 & 37 & $\mathrm{C}$ & 17.568397 & -0.841398 & 1.707001 \\
\hline 38 & $\mathrm{C}$ & 18.948584 & -0.729767 & 1.97195 & 38 & $\mathrm{C}$ & 19.106497 & -0.843898 & 1.849001 \\
\hline 39 & $\mathrm{C}$ & 16.824359 & -2.104866 & 2.133062 & 39 & $\mathrm{C}$ & 16.982097 & -2.241298 & 1.988601 \\
\hline 40 & $\mathrm{C}$ & 17.00031 & 2.218894 & -1.637466 & 40 & $\mathrm{C}$ & 16.969797 & 2.360302 & -1.491999 \\
\hline 41 & $\mathrm{C}$ & 17.178807 & 2.588006 & 0.860265 & 41 & $\mathrm{C}$ & 17.205797 & 2.558002 & 1.031301 \\
\hline 42 & $\mathrm{C}$ & 8.454211 & -5.703387 & -1.071733 & 42 & $\mathrm{C}$ & 8.442897 & -5.721798 & -1.079999 \\
\hline 43 & $\mathrm{C}$ & 8.447685 & -7.09946 & -1.074271 & 43 & $\mathrm{C}$ & 8.430197 & -7.120998 & -1.088999 \\
\hline
\end{tabular}




\begin{tabular}{|c|c|c|c|c|c|c|c|c|c|}
\hline 44 & $\mathrm{C}$ & 8.873518 & -7.810932 & 0.060006 & 44 & $\mathrm{C}$ & 8.879097 & -7.836098 & 0.034401 \\
\hline 45 & $\mathrm{C}$ & 9.29634 & -7.100848 & 1.196275 & 45 & $\mathrm{C}$ & 9.317597 & -7.128598 & 1.166701 \\
\hline 46 & $\mathrm{C}$ & 9.300926 & -5.704512 & 1.189981 & 46 & $\mathrm{C}$ & 9.339397 & -5.732698 & 1.169701 \\
\hline 47 & $\mathrm{C}$ & 9.446004 & 7.043267 & -1.104017 & 47 & $\mathrm{C}$ & 9.581698 & 7.066102 & -0.993699 \\
\hline 48 & $\mathrm{C}$ & 9.032106 & 7.758631 & 0.032235 & 48 & $\mathrm{C}$ & 9.124598 & 7.767802 & 0.134401 \\
\hline 49 & $\mathrm{C}$ & 8.58615 & 7.05281 & 1.162217 & 49 & $\mathrm{C}$ & 8.613198 & 7.049602 & 1.228401 \\
\hline 50 & $\mathrm{C}$ & 8.563636 & 5.656816 & 1.154876 & 50 & $\mathrm{C}$ & 8.580997 & 5.653702 & 1.209701 \\
\hline 51 & $\mathrm{H}$ & 4.407238 & 2.660601 & -0.065445 & 51 & $\mathrm{H}$ & 4.459097 & 2.689002 & -0.080599 \\
\hline 52 & $\mathrm{H}$ & 4.352947 & -2.62037 & 0.10636 & 52 & $\mathrm{H}$ & 4.377897 & -2.619198 & 0.067901 \\
\hline 53 & $\mathrm{H}$ & 11.647909 & 4.504523 & 0.118349 & 53 & $\mathrm{H}$ & 11.725197 & 4.489602 & 0.184901 \\
\hline 54 & $\mathrm{H}$ & 13.521433 & 2.570446 & 0.113359 & 54 & $\mathrm{H}$ & 13.585297 & 2.549502 & 0.164501 \\
\hline 55 & $\mathrm{H}$ & 6.319997 & 4.559329 & -0.07203 & 55 & $\mathrm{H}$ & 6.378297 & 4.571902 & -0.047799 \\
\hline 56 & $\mathrm{H}$ & 6.226551 & -4.556999 & 0.134512 & 56 & $\mathrm{H}$ & 6.240097 & -4.558098 & 0.099601 \\
\hline 57 & $\mathrm{H}$ & 13.467789 & -2.715245 & -0.025807 & 57 & $\mathrm{H}$ & 13.507397 & -2.753098 & -0.014599 \\
\hline 58 & $\mathrm{H}$ & 11.55511 & -4.610958 & -0.027449 & 58 & $\mathrm{H}$ & 11.589097 & -4.637698 & -0.027899 \\
\hline 59 & $\mathrm{H}$ & 17.426275 & -2.36786 & -0.84976 & 59 & $\mathrm{H}$ & 17.613797 & -2.285098 & -1.049799 \\
\hline 60 & $\mathrm{H}$ & 19.619805 & -1.139187 & -0.952024 & 60 & $\mathrm{H}$ & 19.733797 & -0.931298 & -1.128499 \\
\hline 61 & $\mathrm{H}$ & 19.019582 & -0.181956 & -2.311471 & 61 & $\mathrm{H}$ & 19.030997 & 0.103702 & -2.381699 \\
\hline 62 & $\mathrm{H}$ & 19.238021 & -1.924572 & -2.488916 & 62 & $\mathrm{H}$ & 19.342797 & -1.603798 & -2.718499 \\
\hline 63 & $\mathrm{H}$ & 15.491381 & -1.68517 & -2.278657 & 63 & $\mathrm{H}$ & 15.589897 & -1.602298 & -2.360699 \\
\hline 64 & $\mathrm{H}$ & 16.861047 & -2.242202 & -3.25895 & 64 & $\mathrm{H}$ & 16.946797 & -2.007698 & -3.431999 \\
\hline 65 & $\mathrm{H}$ & 16.508283 & -0.51655 & -3.123419 & 65 & $\mathrm{H}$ & 16.512797 & -0.315998 & -3.145199 \\
\hline 66 & $\mathrm{H}$ & 18.607585 & 1.561461 & -0.372416 & 66 & $\mathrm{H}$ & 18.647897 & 1.685602 & -0.314999 \\
\hline 67 & $\mathrm{H}$ & 16.988646 & 0.006837 & 2.446433 & 67 & $\mathrm{H}$ & 17.157697 & -0.149698 & 2.458201 \\
\hline 68 & $\mathrm{H}$ & 19.400051 & 0.243125 & 1.743881 & 68 & $\mathrm{H}$ & 19.541097 & 0.148402 & 1.677401 \\
\hline 69 & $\mathrm{H}$ & 19.444874 & -1.48085 & 1.34504 & 69 & $\mathrm{H}$ & 19.571297 & -1.541498 & 1.140701 \\
\hline 70 & $\mathrm{H}$ & 19.196788 & -0.969697 & 3.014817 & 70 & $\mathrm{H}$ & 19.399697 & -1.163698 & 2.858301 \\
\hline 71 & $\mathrm{H}$ & 15.732334 & -2.109215 & 2.045803 & 71 & $\mathrm{H}$ & 15.887297 & -2.237498 & 1.944401 \\
\hline 72 & $\mathrm{H}$ & 17.07708 & -2.372033 & 3.168207 & 72 & $\mathrm{H}$ & 17.276497 & -2.590198 & 2.988101 \\
\hline 73 & $\mathrm{H}$ & 17.21476 & -2.904996 & 1.49092 & 73 & $\mathrm{H}$ & 17.347597 & -2.982598 & 1.265601 \\
\hline 74 & $\mathrm{H}$ & 15.905011 & 2.272494 & -1.655313 & 74 & $\mathrm{H}$ & 15.873097 & 2.368902 & -1.465599 \\
\hline 75 & $\mathrm{H}$ & 17.313649 & 1.620208 & -2.499895 & 75 & $\mathrm{H}$ & 17.275097 & 1.828002 & -2.399799 \\
\hline
\end{tabular}




\begin{tabular}{|c|c|c|c|c|c|c|c|c|c|}
\hline 76 & $\mathrm{H}$ & 17.382505 & 3.237743 & -1.788806 & 76 & $\mathrm{H}$ & 17.308797 & 3.401102 & -1.587299 \\
\hline 77 & $\mathrm{H}$ & 17.620881 & 2.257589 & 1.806879 & 77 & $\mathrm{H}$ & 17.681597 & 2.168402 & 1.938601 \\
\hline 78 & $\mathrm{H}$ & 16.09533 & 2.669615 & 1.013855 & 78 & $\mathrm{H}$ & 16.122497 & 2.581202 & 1.206501 \\
\hline 79 & $\mathrm{H}$ & 17.556309 & 3.599277 & 0.656304 & 79 & $\mathrm{H}$ & 17.541197 & 3.595902 & 0.899501 \\
\hline 80 & $\mathrm{H}$ & 8.135774 & -5.183434 & -1.969326 & 80 & $\mathrm{H}$ & 8.107797 & -5.200698 & -1.968499 \\
\hline 81 & $\mathrm{O}$ & 8.096083 & -7.757899 & -2.228665 & 81 & $\mathrm{O}$ & 8.045297 & -7.756398 & -2.269599 \\
\hline 82 & $\mathrm{O}$ & 8.870923 & -9.189037 & 0.061122 & 82 & $\mathrm{O}$ & 8.877097 & -9.239298 & 0.021501 \\
\hline 83 & $\mathrm{O}$ & 9.779904 & -7.75786 & 2.302134 & 83 & $\mathrm{O}$ & 9.808497 & -7.808798 & 2.289601 \\
\hline 84 & $\mathrm{H}$ & 9.637206 & -5.185258 & 2.081483 & 84 & $\mathrm{H}$ & 9.690997 & -5.220898 & 2.057401 \\
\hline 85 & $\mathrm{O}$ & 9.947899 & 7.694744 & -2.205271 & 85 & $\mathrm{O}$ & 10.157098 & 7.714902 & -2.086799 \\
\hline 86 & $\mathrm{O}$ & 9.057631 & 9.136571 & 0.036447 & 86 & $\mathrm{O}$ & 9.177498 & 9.170202 & 0.162801 \\
\hline 87 & $\mathrm{O}$ & 8.243018 & 7.713845 & 2.317578 & 87 & $\mathrm{O}$ & 8.205098 & 7.711902 & 2.393501 \\
\hline 88 & $\mathrm{H}$ & 8.230001 & 5.140746 & 2.049182 & 88 & $\mathrm{H}$ & 8.201597 & 5.131902 & 2.079901 \\
\hline 89 & $\mathrm{C}$ & 9.422489 & 5.647253 & -1.102205 & 89 & $\mathrm{C}$ & 9.544297 & 5.667702 & -1.012399 \\
\hline 90 & $\mathrm{H}$ & 9.752815 & 5.123871 & -1.993516 & 90 & $\mathrm{H}$ & 9.907397 & 5.156402 & -1.895699 \\
\hline 91 & $\mathrm{C}$ & 1.454393 & 0.039585 & -0.00384 & 91 & $\mathrm{C}$ & 1.445597 & 0.072202 & -0.066499 \\
\hline 92 & $\mathrm{C}$ & -1.402763 & 0.051626 & -0.02745 & 92 & $\mathrm{C}$ & -1.397603 & 0.100002 & -0.111699 \\
\hline 93 & $\mathrm{C}$ & 0.712324 & -1.158026 & 0.019612 & 93 & $\mathrm{C}$ & 0.706497 & -1.135398 & -0.086599 \\
\hline 94 & $\mathrm{C}$ & -0.671363 & -1.152323 & 0.008139 & 94 & $\mathrm{C}$ & -0.681903 & -1.121898 & -0.108799 \\
\hline 95 & $\mathrm{C}$ & -0.660622 & 1.249187 & -0.05047 & 95 & $\mathrm{C}$ & -0.658603 & 1.307602 & -0.093099 \\
\hline 96 & $\mathrm{C}$ & 0.723042 & 1.243394 & -0.039164 & 96 & $\mathrm{C}$ & 0.730097 & 1.294002 & -0.070899 \\
\hline 97 & $\mathrm{~F}$ & 1.38326 & 2.411219 & -0.062829 & 97 & $\mathrm{C}$ & -2.817803 & 0.111402 & -0.130499 \\
\hline 98 & $\mathrm{~F}$ & -1.310353 & 2.422669 & -0.084657 & 98 & $\mathrm{C}$ & -4.041103 & 0.112802 & -0.142999 \\
\hline 99 & $\mathrm{~F}$ & 1.362062 & -2.331209 & 0.054494 & 99 & $\mathrm{C}$ & -7.707403 & 2.921902 & -0.175599 \\
\hline 100 & $\mathrm{~F}$ & -1.331178 & -2.319833 & 0.032155 & 100 & $\mathrm{C}$ & -6.426803 & 3.596802 & -0.240899 \\
\hline 101 & $\mathrm{C}$ & -2.810826 & 0.056927 & -0.038963 & 101 & $\mathrm{C}$ & -5.457203 & 2.633202 & -0.230399 \\
\hline 102 & $\mathrm{C}$ & -4.028241 & 0.058835 & -0.049672 & 102 & $\mathrm{C}$ & -6.126403 & 1.354802 & -0.170099 \\
\hline 103 & $\mathrm{C}$ & -7.637484 & 2.882586 & -0.072234 & 103 & $\mathrm{~N}$ & -7.497503 & 1.543902 & -0.140799 \\
\hline 104 & $\mathrm{C}$ & -6.356824 & 3.550964 & -0.118889 & 104 & $\mathrm{C}$ & -5.463603 & 0.105602 & -0.150799 \\
\hline 105 & $\mathrm{C}$ & -5.398974 & 2.583296 & -0.111238 & 105 & $\mathrm{C}$ & -8.957203 & 3.565703 & -0.168299 \\
\hline 106 & $\mathrm{C}$ & -6.09017 & 1.319717 & -0.070794 & 106 & $\mathrm{C}$ & -11.757603 & 1.318203 & -0.104699 \\
\hline 107 & $\mathrm{~N}$ & -7.444659 & 1.515369 & -0.048981 & 107 & $\mathrm{C}$ & -12.444103 & 2.589403 & -0.068799 \\
\hline
\end{tabular}




\begin{tabular}{|c|c|c|c|c|c|c|c|c|c|}
\hline 108 & $\mathrm{C}$ & -5.44511 & 0.060781 & -0.060338 & 108 & $\mathrm{C}$ & -11.488403 & 3.565703 & -0.089999 \\
\hline 109 & $\mathrm{C}$ & -8.881576 & 3.535291 & -0.070274 & 109 & $\mathrm{C}$ & -10.198503 & 2.906203 & -0.147699 \\
\hline 110 & $\mathrm{C}$ & -11.683578 & 1.325315 & -0.068531 & 110 & $\mathrm{~N}$ & -10.388303 & 1.525403 & -0.150399 \\
\hline 111 & $\mathrm{C}$ & -12.366133 & 2.592735 & -0.024204 & 111 & $\mathrm{C}$ & -12.403003 & 0.062703 & -0.093299 \\
\hline 112 & $\mathrm{C}$ & -11.405836 & 3.557651 & -0.019563 & 112 & $\mathrm{C}$ & -10.162103 & -2.753497 & -0.138299 \\
\hline 113 & $\mathrm{C}$ & -10.129118 & 2.883544 & -0.070326 & 113 & $\mathrm{C}$ & -11.444303 & -3.427997 & -0.180999 \\
\hline 114 & $\mathrm{~N}$ & -10.325564 & 1.51838 & -0.094766 & 114 & $\mathrm{C}$ & -12.413203 & -2.464097 & -0.159999 \\
\hline 115 & $\mathrm{C}$ & -12.335644 & 0.071648 & -0.080254 & 115 & $\mathrm{C}$ & -11.741803 & -1.185197 & -0.116899 \\
\hline 116 & $\mathrm{C}$ & -10.135947 & -2.746373 & -0.104523 & 116 & $\mathrm{~N}$ & -10.369803 & -1.375897 & -0.108599 \\
\hline 117 & $\mathrm{C}$ & -11.413859 & -3.416115 & -0.170458 & 117 & $\mathrm{C}$ & -8.912503 & -3.398098 & -0.143599 \\
\hline 118 & $\mathrm{C}$ & -12.372426 & -2.448951 & -0.160935 & 118 & $\mathrm{C}$ & -6.111003 & -1.151598 & -0.138699 \\
\hline 119 & $\mathrm{C}$ & -11.686815 & -1.184061 & -0.099786 & 119 & $\mathrm{C}$ & -5.425203 & -2.422298 & -0.098599 \\
\hline 120 & $\mathrm{~N}$ & -10.329643 & -1.381292 & -0.068797 & 120 & $\mathrm{C}$ & -6.381503 & -3.398498 & -0.096799 \\
\hline 121 & $\mathrm{C}$ & -8.890516 & -3.402732 & -0.097546 & 121 & $\mathrm{C}$ & -7.671103 & -2.738998 & -0.144199 \\
\hline 122 & $\mathrm{C}$ & -6.093698 & -1.196257 & -0.061038 & 122 & $\mathrm{~N}$ & -7.479803 & -1.357598 & -0.162399 \\
\hline 123 & $\mathrm{C}$ & -5.406287 & -2.462242 & -0.021847 & 123 & $\mathrm{Zn}$ & -8.934603 & 0.084002 & -0.147599 \\
\hline 124 & $\mathrm{C}$ & -6.366192 & -3.427406 & -0.029996 & 124 & $\mathrm{C}$ & -8.903003 & -4.898598 & -0.139799 \\
\hline 125 & $\mathrm{C}$ & -7.644564 & -2.754721 & -0.083354 & 125 & $\mathrm{C}$ & -8.967203 & 5.066303 & -0.174099 \\
\hline 126 & $\mathrm{~N}$ & -7.44856 & -1.387526 & -0.095954 & 126 & $\mathrm{C}$ & -13.830803 & 0.051103 & -0.049199 \\
\hline 127 & $\mathrm{Zn}$ & -8.887201 & 0.066251 & -0.084589 & 127 & $\mathrm{C}$ & -15.057903 & 0.031403 & 0.001501 \\
\hline 128 & C & -8.895796 & -4.901758 & -0.101063 & 128 & $\mathrm{Si}$ & -16.927403 & 0.006603 & 0.120401 \\
\hline 129 & $\mathrm{C}$ & -8.879861 & 5.034276 & -0.060902 & 129 & $\mathrm{C}$ & -17.465903 & 1.876303 & 0.029401 \\
\hline 130 & $\mathrm{C}$ & -13.762639 & 0.071726 & -0.069251 & 130 & $\mathrm{C}$ & -17.602703 & -0.961297 & -1.434299 \\
\hline 131 & $\mathrm{C}$ & -14.986122 & 0.066244 & -0.056677 & 131 & $\mathrm{C}$ & -17.310403 & -0.805297 & 1.852301 \\
\hline 132 & $\mathrm{Si}$ & -16.833346 & 0.070677 & -0.020028 & 132 & $\mathrm{C}$ & -16.801303 & -2.261297 & 1.929701 \\
\hline 133 & $\mathrm{C}$ & -17.324129 & 1.923622 & -0.139925 & 133 & $\mathrm{C}$ & -18.784603 & -0.704697 & 2.300601 \\
\hline 134 & $\mathrm{C}$ & -17.444188 & -0.876404 & -1.579783 & 134 & $\mathrm{C}$ & -16.664703 & -2.095397 & -1.904199 \\
\hline 135 & $\mathrm{C}$ & -17.315182 & -0.71184 & 1.666373 & 135 & $\mathrm{C}$ & -19.044103 & -1.491597 & -1.256299 \\
\hline 136 & $\mathrm{C}$ & -16.848421 & -2.174942 & 1.795659 & 136 & $\mathrm{C}$ & -17.028503 & 2.659603 & 1.286501 \\
\hline 137 & $\mathrm{C}$ & -18.799459 & -0.575952 & 2.059684 & 137 & $\mathrm{C}$ & -18.964003 & 2.097003 & -0.274399 \\
\hline 138 & $\mathrm{C}$ & -16.523921 & -2.038168 & -2.003072 & 138 & $\mathrm{C}$ & -8.491303 & 5.779002 & 0.944801 \\
\hline 139 & $\mathrm{C}$ & -18.905214 & -1.363104 & -1.491575 & 139 & $\mathrm{C}$ & -8.515802 & 7.174102 & 0.944301 \\
\hline
\end{tabular}




\begin{tabular}{|c|c|c|c|c|c|c|c|c|c|}
\hline 140 & $\mathrm{C}$ & -16.93908 & 2.709849 & 1.12821 & 140 & $\mathrm{C}$ & -8.993302 & 7.895903 & -0.173799 \\
\hline 141 & $\mathrm{C}$ & -18.787387 & 2.198885 & -0.53559 & 141 & $\mathrm{C}$ & -9.458002 & 7.178503 & -1.289999 \\
\hline 142 & $\mathrm{C}$ & -8.439789 & 5.72844 & 1.079057 & 142 & $\mathrm{C}$ & -9.446703 & 5.773003 & -1.278299 \\
\hline 143 & $\mathrm{C}$ & -8.445214 & 7.123101 & 1.093857 & 143 & $\mathrm{C}$ & -8.433103 & -5.612498 & -1.243599 \\
\hline 144 & $\mathrm{C}$ & -8.866072 & 7.858565 & -0.040202 & 144 & $\mathrm{C}$ & -8.422903 & -7.017998 & -1.246799 \\
\hline 145 & $\mathrm{C}$ & -9.299157 & 7.156665 & -1.177916 & 145 & $\mathrm{C}$ & -8.878703 & -7.728298 & -0.122399 \\
\hline 146 & $\mathrm{C}$ & -9.307182 & 5.752436 & -1.174142 & 146 & $\mathrm{C}$ & -9.346303 & -6.999297 & 0.995301 \\
\hline 147 & $\mathrm{C}$ & -8.464251 & -5.610959 & -1.218249 & 147 & $\mathrm{C}$ & -9.369703 & -5.604297 & 0.987401 \\
\hline 148 & $\mathrm{C}$ & -8.475021 & -7.015252 & -1.234603 & 148 & $\mathrm{H}$ & -4.354103 & -2.542298 & -0.069499 \\
\hline 149 & $\mathrm{C}$ & -8.915304 & -7.726004 & -0.105209 & 149 & $\mathrm{H}$ & -4.387703 & 2.765302 & -0.272399 \\
\hline 150 & $\mathrm{C}$ & -9.340143 & -6.999448 & 1.0332 & 150 & $\mathrm{H}$ & -6.292603 & 4.664702 & -0.298399 \\
\hline 151 & $\mathrm{C}$ & -9.343109 & -5.604798 & 1.03066 & 151 & $\mathrm{H}$ & -13.515303 & 2.707403 & -0.029699 \\
\hline 152 & $\mathrm{H}$ & -4.332313 & -2.582782 & 0.012888 & 152 & $\mathrm{H}$ & -11.637503 & 4.632903 & -0.066799 \\
\hline 153 & $\mathrm{H}$ & -4.324329 & 2.700018 & -0.139393 & 153 & $\mathrm{H}$ & -11.579803 & -4.496097 & -0.231499 \\
\hline 154 & $\mathrm{H}$ & -6.216118 & 4.620903 & -0.160731 & 154 & $\mathrm{H}$ & -13.483303 & -2.594597 & -0.186699 \\
\hline 155 & $\mathrm{H}$ & -13.439368 & 2.714999 & 0.003803 & 155 & $\mathrm{H}$ & -6.232403 & -4.465298 & -0.063899 \\
\hline 156 & $\mathrm{H}$ & -11.542732 & 4.628203 & 0.017375 & 156 & $\mathrm{H}$ & -16.893003 & 2.269403 & -0.825699 \\
\hline 157 & $\mathrm{H}$ & -11.552498 & -4.485696 & -0.226062 & 157 & $\mathrm{H}$ & -17.621703 & -0.198197 & -2.229699 \\
\hline 158 & $\mathrm{H}$ & -13.445535 & -2.567693 & -0.205145 & 158 & $\mathrm{H}$ & -16.706703 & -0.207297 & 2.552801 \\
\hline 159 & $\mathrm{H}$ & -6.228159 & -4.498058 & -0.00012 & 159 & $\mathrm{H}$ & -16.920603 & -2.657197 & 2.947801 \\
\hline 160 & $\mathrm{H}$ & -16.692752 & 2.299127 & -0.960793 & 160 & $\mathrm{H}$ & -15.739903 & -2.332197 & 1.666201 \\
\hline 161 & $\mathrm{H}$ & -17.397143 & -0.119418 & -2.379429 & 161 & $\mathrm{H}$ & -17.363503 & -2.919497 & 1.255601 \\
\hline 162 & $\mathrm{H}$ & -16.732086 & -0.123024 & 2.391454 & 162 & $\mathrm{H}$ & -19.452103 & -1.263397 & 1.634901 \\
\hline 163 & $\mathrm{H}$ & -17.019008 & -2.548585 & 2.814699 & 163 & $\mathrm{H}$ & -19.134903 & 0.332803 & 2.333701 \\
\hline 164 & $\mathrm{H}$ & -15.779984 & -2.282773 & 1.577973 & 164 & $\mathrm{H}$ & -18.904103 & -1.124197 & 3.309401 \\
\hline 165 & $\mathrm{H}$ & -17.398046 & -2.836186 & 1.1143 & 165 & $\mathrm{H}$ & -16.602203 & -2.898597 & -1.158899 \\
\hline 166 & $\mathrm{H}$ & -19.457377 & -1.12414 & 1.376114 & 166 & $\mathrm{H}$ & -15.649403 & -1.731597 & -2.090799 \\
\hline 167 & $\mathrm{H}$ & -19.132134 & 0.467727 & 2.073571 & 167 & $\mathrm{H}$ & -17.042603 & -2.541397 & -2.834599 \\
\hline 168 & $\mathrm{H}$ & -18.967578 & -0.984277 & 3.065827 & 168 & $\mathrm{H}$ & -19.746803 & -0.710097 & -0.947199 \\
\hline 169 & $\mathrm{H}$ & -16.516783 & -2.839419 & -1.253553 & 169 & $\mathrm{H}$ & -19.082303 & -2.291897 & -0.507199 \\
\hline 170 & $\mathrm{H}$ & -15.490159 & -1.709243 & -2.146782 & 170 & $\mathrm{H}$ & -19.412803 & -1.913997 & -2.201299 \\
\hline 171 & $\mathrm{H}$ & -16.871684 & -2.481384 & -2.946352 & 171 & $\mathrm{H}$ & -15.956203 & 2.546003 & 1.484301 \\
\hline
\end{tabular}




\begin{tabular}{|c|c|c|c|c|c|c|c|c|c|}
\hline 172 & $\mathrm{H}$ & -19.604945 & -0.56498 & -1.221144 & 172 & $\mathrm{H}$ & -17.571103 & 2.321803 & 2.178801 \\
\hline 173 & $\mathrm{H}$ & -19.014039 & -2.163563 & -0.749991 & 173 & $\mathrm{H}$ & -17.235303 & 3.731903 & 1.165201 \\
\hline 174 & $\mathrm{H}$ & -19.232664 & -1.773405 & -2.456592 & 174 & $\mathrm{H}$ & -19.605103 & 1.706503 & 0.525501 \\
\hline 175 & $\mathrm{H}$ & -15.886188 & 2.565091 & 1.396925 & 175 & $\mathrm{H}$ & -19.268403 & 1.620003 & -1.213099 \\
\hline 176 & $\mathrm{H}$ & -17.54483 & 2.405438 & 1.990881 & 176 & $\mathrm{H}$ & -19.178803 & 3.170703 & -0.367099 \\
\hline 177 & $\mathrm{H}$ & -17.100311 & 3.786895 & 0.984592 & 177 & $\mathrm{H}$ & -8.131903 & 5.230702 & 1.805301 \\
\hline 178 & $\mathrm{H}$ & -19.494566 & 1.831469 & 0.217663 & 178 & $\mathrm{O}$ & -8.103902 & 7.951002 & 2.024501 \\
\hline 179 & $\mathrm{H}$ & -19.050555 & 1.734768 & -1.492533 & 179 & $\mathrm{O}$ & -9.118302 & 9.287903 & -0.144199 \\
\hline 180 & $\mathrm{H}$ & -18.960892 & 3.278789 & -0.639059 & 180 & $\mathrm{O}$ & -9.999002 & 7.728603 & -2.441599 \\
\hline 181 & $\mathrm{H}$ & -8.121814 & 5.166708 & 1.948443 & 181 & $\mathrm{H}$ & -9.808903 & 5.259403 & -2.159899 \\
\hline 182 & $\mathrm{O}$ & -8.087417 & 7.877154 & 2.176132 & 182 & $\mathrm{H}$ & -8.078103 & -5.104498 & -2.131399 \\
\hline 183 & $\mathrm{O}$ & -8.960828 & 9.230257 & 0.003906 & 183 & $\mathrm{O}$ & -7.891403 & -7.575898 & -2.399099 \\
\hline 184 & $\mathrm{O}$ & -9.789426 & 7.727976 & -2.315853 & 184 & $\mathrm{O}$ & -8.754603 & -9.120098 & -0.085899 \\
\hline 185 & $\mathrm{H}$ & -9.642169 & 5.245975 & -2.072751 & 185 & $\mathrm{O}$ & -9.749403 & -7.769297 & 2.083701 \\
\hline 186 & $\mathrm{H}$ & -8.123197 & -5.097295 & -2.110457 & 186 & $\mathrm{H}$ & -9.721603 & -5.050497 & 1.847501 \\
\hline 187 & $\mathrm{O}$ & -7.98034 & -7.576177 & -2.375545 & 187 & $\mathrm{C}$ & 7.016998 & 8.570702 & 2.274201 \\
\hline 188 & $\mathrm{O}$ & -8.823807 & -9.098301 & -0.071664 & 188 & $\mathrm{C}$ & 10.297498 & 9.726102 & 0.945501 \\
\hline 189 & $\mathrm{O}$ & -9.704685 & -7.762405 & 2.107043 & 189 & $\mathrm{C}$ & 9.330898 & 8.692202 & -2.809499 \\
\hline 190 & $\mathrm{H}$ & -9.664249 & -5.050051 & 1.903372 & 190 & $\mathrm{C}$ & 8.828097 & -8.604098 & 3.045701 \\
\hline 191 & $\mathrm{C}$ & 7.040828 & 8.488446 & 2.25057 & 191 & $\mathrm{C}$ & 10.206797 & -9.857798 & -0.139499 \\
\hline 192 & $\mathrm{C}$ & 10.297004 & 9.68598 & 0.503903 & 192 & $\mathrm{C}$ & 6.926697 & -8.706598 & -2.199699 \\
\hline 193 & $\mathrm{C}$ & 8.999078 & 8.464821 & -2.951821 & 193 & $\mathrm{C}$ & -10.126603 & -7.094497 & 3.313801 \\
\hline 194 & $\mathrm{C}$ & 8.814693 & -8.511985 & 3.043927 & 194 & $\mathrm{C}$ & -9.975003 & -9.914097 & 0.110501 \\
\hline 195 & $\mathrm{C}$ & 10.087762 & -9.765777 & -0.431867 & 195 & $\mathrm{C}$ & -8.197403 & -8.937498 & -2.829699 \\
\hline 196 & $\mathrm{C}$ & 6.873805 & -8.5012 & -2.165197 & 196 & $\mathrm{C}$ & -7.718602 & 7.284102 & 3.256401 \\
\hline 197 & $\mathrm{C}$ & -10.071325 & -7.100316 & 3.30853 & 197 & $\mathrm{C}$ & -7.896902 & 10.084002 & 0.036201 \\
\hline 198 & $\mathrm{C}$ & -10.054182 & -9.82073 & 0.040216 & 198 & $\mathrm{C}$ & -9.704102 & 9.090203 & -2.879899 \\
\hline 199 & $\mathrm{C}$ & -8.47397 & -8.825131 & -2.856393 & 199 & $\mathrm{H}$ & 6.144898 & 7.970802 & 1.990601 \\
\hline 200 & $\mathrm{C}$ & -7.718759 & 7.205081 & 3.371544 & 200 & $\mathrm{H}$ & 7.184998 & 9.362902 & 1.541301 \\
\hline 201 & $\mathrm{C}$ & -7.732814 & 9.954673 & 0.129947 & 201 & $\mathrm{H}$ & 6.869198 & 8.991902 & 3.268601 \\
\hline 202 & $\mathrm{C}$ & -9.285015 & 8.976162 & -2.78772 & 202 & $\mathrm{H}$ & 11.250898 & 9.408302 & 0.512701 \\
\hline 203 & $\mathrm{H}$ & 6.178453 & 7.846864 & 2.025898 & 203 & $\mathrm{H}$ & 10.223498 & 9.404402 & 1.987601 \\
\hline
\end{tabular}




\begin{tabular}{|c|c|c|c|c|c|c|c|c|c|}
\hline 204 & $\mathrm{H}$ & 7.118132 & 9.279499 & 1.498802 & 204 & $\mathrm{H}$ & 10.192598 & 10.808502 & 0.871501 \\
\hline 205 & $\mathrm{H}$ & 6.912102 & 8.930252 & 3.241284 & 205 & $\mathrm{H}$ & 9.025298 & 9.504602 & -2.148299 \\
\hline 206 & $\mathrm{H}$ & 11.126589 & 9.373928 & -0.140889 & 206 & $\mathrm{H}$ & 8.450698 & 8.198502 & -3.237299 \\
\hline 207 & $\mathrm{H}$ & 10.491353 & 9.378611 & 1.537832 & 207 & $\mathrm{H}$ & 9.970998 & 9.064402 & -3.609399 \\
\hline 208 & $\mathrm{H}$ & 10.186 & 10.771867 & 0.458729 & 208 & $\mathrm{H}$ & 8.380197 & -9.370298 & 2.408801 \\
\hline 209 & $\mathrm{H}$ & 8.565666 & 9.262512 & -2.34136 & 209 & $\mathrm{H}$ & 8.050797 & -7.950898 & 3.457401 \\
\hline 210 & $\mathrm{H}$ & 8.199994 & 7.821245 & -3.342594 & 210 & $\mathrm{H}$ & 9.395897 & -9.061498 & 3.855901 \\
\hline 211 & $\mathrm{H}$ & 9.554078 & 8.897664 & -3.787215 & 211 & $\mathrm{H}$ & 10.027597 & -10.932898 & -0.127799 \\
\hline 212 & $\mathrm{H}$ & 8.373799 & -9.304759 & 2.432539 & 212 & $\mathrm{H}$ & 10.858697 & -9.568198 & 0.688601 \\
\hline 213 & $\mathrm{H}$ & 8.022534 & -7.855721 & 3.42768 & 213 & $\mathrm{H}$ & 10.645897 & -9.558298 & -1.095999 \\
\hline 214 & $\mathrm{H}$ & 9.357609 & -8.950733 & 3.884176 & 214 & $\mathrm{H}$ & 6.014197 & -8.191698 & -1.877099 \\
\hline 215 & $\mathrm{H}$ & 9.955064 & -10.84893 & -0.380262 & 215 & $\mathrm{H}$ & 7.158197 & -9.527598 & -1.519699 \\
\hline 216 & $\mathrm{H}$ & 10.937759 & -9.469338 & 0.193596 & 216 & $\mathrm{H}$ & 6.803897 & -9.070998 & -3.219599 \\
\hline 217 & $\mathrm{H}$ & 10.265756 & -9.465698 & -1.470762 & 217 & $\mathrm{H}$ & -9.303603 & -6.478697 & 3.693001 \\
\hline 218 & $\mathrm{H}$ & 6.026713 & -7.836227 & -1.951002 & 218 & $\mathrm{H}$ & -10.345703 & -7.894897 & 4.019501 \\
\hline 219 & $\mathrm{H}$ & 6.925657 & -9.288715 & -1.407512 & 219 & $\mathrm{H}$ & -11.017403 & -6.471997 & 3.170801 \\
\hline 220 & $\mathrm{H}$ & 6.740775 & -8.946415 & -3.153771 & 220 & $\mathrm{H}$ & -10.703403 & -9.699497 & -0.681199 \\
\hline 221 & $\mathrm{H}$ & -9.251441 & -6.478282 & 3.689184 & 221 & $\mathrm{H}$ & -10.409603 & -9.710397 & 1.089201 \\
\hline 222 & $\mathrm{H}$ & -10.29019 & -7.891343 & 4.028046 & 222 & $\mathrm{H}$ & -9.648303 & -10.952197 & 0.043301 \\
\hline 223 & $\mathrm{H}$ & -10.96413 & -6.47655 & 3.170996 & 223 & $\mathrm{H}$ & -9.279003 & -9.113397 & -2.838899 \\
\hline 224 & $\mathrm{H}$ & -10.723095 & -9.589471 & -0.799851 & 224 & $\mathrm{H}$ & -7.712003 & -9.673598 & -2.190199 \\
\hline 225 & $\mathrm{H}$ & -10.560843 & -9.601389 & 0.983007 & 225 & $\mathrm{H}$ & -7.808603 & -8.989298 & -3.847399 \\
\hline 226 & $\mathrm{H}$ & -9.783536 & -10.87866 & 0.004902 & 226 & $\mathrm{H}$ & -8.539203 & 6.670902 & 3.645001 \\
\hline 227 & $\mathrm{H}$ & -9.569846 & -8.862363 & -2.813577 & 227 & $\mathrm{H}$ & -7.494702 & 8.088902 & 3.955601 \\
\hline 228 & $\mathrm{H}$ & -8.059133 & -9.66791 & -2.299921 & 228 & $\mathrm{H}$ & -6.829003 & 6.660402 & 3.111501 \\
\hline 229 & $\mathrm{H}$ & -8.157406 & -8.876488 & -3.901333 & 229 & $\mathrm{H}$ & -8.224802 & 11.121302 & -0.035699 \\
\hline 230 & $\mathrm{H}$ & -8.536576 & 6.576664 & 3.746168 & 230 & $\mathrm{H}$ & -7.175002 & 9.864102 & -0.760099 \\
\hline 231 & $\mathrm{H}$ & -7.502918 & 7.990113 & 4.098482 & 231 & $\mathrm{H}$ & -7.453902 & 9.887602 & 1.012601 \\
\hline 232 & $\mathrm{H}$ & -6.823758 & 6.585841 & 3.228351 & 232 & $\mathrm{H}$ & -8.623702 & 9.272102 & -2.898999 \\
\hline 233 & $\mathrm{H}$ & -8.005697 & 11.012192 & 0.100066 & 233 & $\mathrm{H}$ & -10.188202 & 9.826103 & -2.239199 \\
\hline 234 & $\mathrm{H}$ & -7.057291 & 9.73078 & -0.706757 & 234 & $\mathrm{H}$ & -10.101902 & 9.135803 & -3.894399 \\
\hline 235 & $\mathrm{H}$ & -7.232615 & 9.729764 & 1.074838 & 235 & $\mathrm{H}$ & -1.191103 & 2.252402 & -0.095599 \\
\hline
\end{tabular}




\begin{tabular}{|lllll|lllll|}
236 & $\mathrm{H}$ & -8.18917 & 9.005756 & -2.738876 & 236 & $\mathrm{H}$ & 1.280797 & 2.228202 & -0.056099 \\
237 & $\mathrm{H}$ & -9.697205 & 9.818701 & -2.228874 & 237 & $\mathrm{H}$ & 1.238897 & -2.080298 & -0.085099 \\
238 & $\mathrm{H}$ & -9.595584 & 9.03536 & -3.834059 & 238 & $\mathrm{H}$ & -1.232503 & -2.056098 & -0.124599 \\
\hline
\end{tabular}

Table S5. Cartesian coordinates of the geometry-optimized structures of 1 and 2 obtained from the DFT B3LYP-D3(BJ) calculations at the 6-311G(d) level for zinc and the 6-31G(d) level for other atoms. Atom numbers are indicated in the labeled structures of 1 (A) and 2 (B).

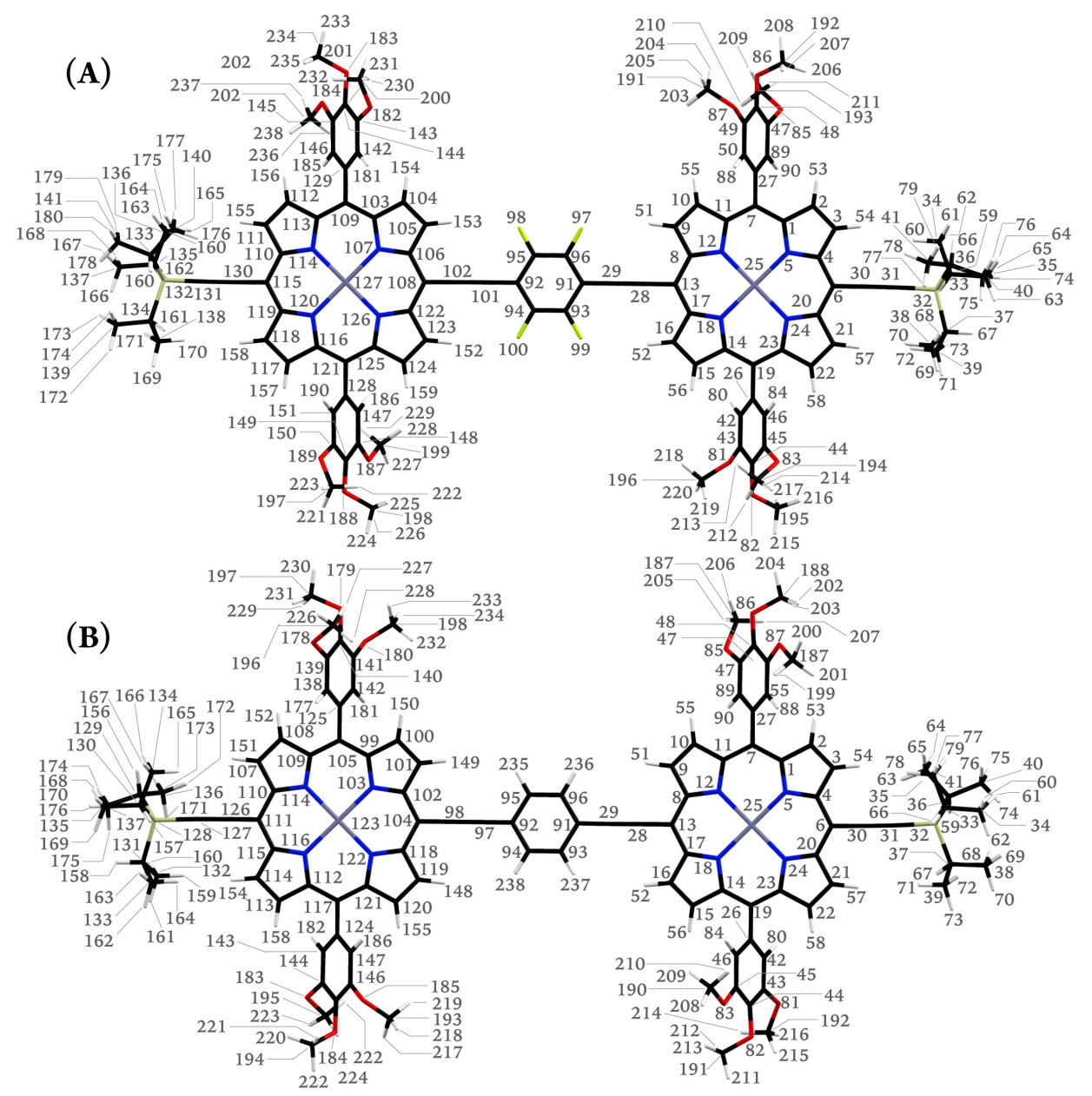

\begin{tabular}{|c|c|c|c|c|c|c|c|c|c|}
\hline \multicolumn{5}{|c|}{1} & \multicolumn{5}{|c|}{2} \\
\hline 1 & $\mathrm{C}$ & 10.1874113 & 2.7223105 & 0.0292693 & 1 & $\mathrm{C}$ & 10.2079859 & 2.7219499 & -0.0278136 \\
\hline 2 & $\mathrm{C}$ & 11.4694151 & 3.3893969 & 0.0845096 & 2 & $\mathrm{C}$ & 11.4906842 & 3.3891096 & 0.0191116 \\
\hline 3 & $\mathrm{C}$ & 12.4244264 & 2.4169393 & 0.0965411 & 3 & $\mathrm{C}$ & 12.4446703 & 2.4165133 & 0.0500837 \\
\hline 4 & $\mathrm{C}$ & 11.7314489 & 1.1530809 & 0.0607665 & 4 & $\mathrm{C}$ & 11.7507588 & 1.1522678 & 0.0341849 \\
\hline 5 & $\mathrm{~N}$ & 10.3764843 & 1.3569616 & 0.0247817 & 5 & $\mathrm{~N}$ & 10.3964022 & 1.3560416 & -0.0082127 \\
\hline 6 & $\mathrm{C}$ & 12.3734443 & -0.1033381 & 0.06441 & 6 & $\mathrm{C}$ & 12.392454 & -0.103938 & 0.0601482 \\
\hline
\end{tabular}




\begin{tabular}{|c|c|c|c|c|c|c|c|c|c|}
\hline 7 & $\mathrm{C}$ & 8.9458509 & 3.3803919 & 0.0034153 & 7 & $\mathrm{C}$ & 8.9679517 & 3.3784091 & -0.0689451 \\
\hline 8 & $\mathrm{C}$ & 6.1422737 & 1.1827884 & -0.0008273 & 8 & $\mathrm{C}$ & 6.1559752 & 1.1846289 & -0.0431911 \\
\hline 9 & $\mathrm{C}$ & 5.4577344 & 2.4503503 & -0.0710835 & 9 & $\mathrm{C}$ & 5.4801084 & 2.4532192 & -0.1427458 \\
\hline 10 & $\mathrm{C}$ & 6.4222508 & 3.4133471 & -0.0825336 & 10 & $\mathrm{C}$ & 6.4466772 & 3.414018 & -0.1680897 \\
\hline 11 & $\mathrm{C}$ & 7.6993075 & 2.7371594 & -0.0070477 & 11 & $\mathrm{C}$ & 7.7196138 & 2.735203 & -0.0726689 \\
\hline 12 & $\mathrm{~N}$ & 7.4963854 & 1.3724302 & 0.032678 & 12 & $\mathrm{~N}$ & 7.5123643 & 1.3729585 & -0.0072774 \\
\hline 13 & $\mathrm{C}$ & 5.489213 & -0.0693189 & 0.0262623 & 13 & $\mathrm{C}$ & 5.4950605 & -0.063701 & 0.0073074 \\
\hline 14 & $\mathrm{C}$ & 7.6710348 & -2.8970809 & 0.0915118 & 14 & $\mathrm{C}$ & 7.6852489 & -2.8878396 & 0.1281221 \\
\hline 15 & $\mathrm{C}$ & 6.3864525 & -3.5607357 & 0.1504235 & 15 & $\mathrm{C}$ & 6.4029898 & -3.5519049 & 0.2016636 \\
\hline 16 & $\mathrm{C}$ & 5.4316623 & -2.5884264 & 0.1247909 & 16 & $\mathrm{C}$ & 5.4481936 & -2.58012 & 0.1582242 \\
\hline 17 & $\mathrm{C}$ & 6.1294782 & -1.3276517 & 0.0630099 & 17 & $\mathrm{C}$ & 6.1403747 & -1.3194672 & 0.0698397 \\
\hline 18 & $\mathrm{~N}$ & 7.4820204 & -1.5304675 & 0.0481793 & 18 & $\mathrm{~N}$ & 7.4949531 & -1.5233561 & 0.0580957 \\
\hline 19 & $\mathrm{C}$ & 8.9112305 & -3.5526103 & 0.0965324 & 19 & $\mathrm{C}$ & 8.9259619 & -3.5454445 & 0.1457805 \\
\hline 20 & $\mathrm{C}$ & 11.7186426 & -1.3527298 & 0.0649441 & 20 & $\mathrm{C}$ & 11.7353539 & -1.351869 & 0.0800292 \\
\hline 21 & $\mathrm{C}$ & 12.3998088 & -2.6229482 & 0.0362674 & 21 & $\mathrm{C}$ & 12.4149486 & -2.6237172 & 0.0747344 \\
\hline 22 & $\mathrm{C}$ & 11.4354565 & -3.5862432 & 0.0410737 & 22 & $\mathrm{C}$ & 11.4495474 & -3.5853355 & 0.0945424 \\
\hline 23 & $\mathrm{C}$ & 10.1593863 & -2.9066708 & 0.0838884 & 23 & $\mathrm{C}$ & 10.1739852 & -2.9033357 & 0.1230297 \\
\hline 24 & $\mathrm{~N}$ & 10.3615212 & -1.5432655 & 0.0895618 & 24 & $\mathrm{~N}$ & 10.3783124 & -1.53977 & 0.1049647 \\
\hline 25 & $\mathrm{Zn}$ & 8.9296665 & -0.0861433 & 0.0487475 & 25 & $\mathrm{Zn}$ & 8.9465341 & -0.0836087 & 0.0366648 \\
\hline 26 & $\mathrm{C}$ & 8.9048884 & -5.0455125 & 0.1145905 & 26 & $\mathrm{C}$ & 8.9168764 & -5.0378345 & 0.1925225 \\
\hline 27 & $\mathrm{C}$ & 8.9545443 & 4.8732927 & -0.0136327 & 27 & $\mathrm{C}$ & 8.9768402 & 4.8709035 & -0.1124785 \\
\hline 28 & $\mathrm{C}$ & 4.0754653 & -0.0619794 & 0.0153148 & 28 & $\mathrm{C}$ & 4.0774001 & -0.0549158 & -0.0055395 \\
\hline 29 & $\mathrm{C}$ & 2.8593401 & -0.0542814 & 0.0051628 & 29 & $\mathrm{C}$ & 2.8591548 & -0.0455372 & -0.0167649 \\
\hline 30 & $\mathrm{C}$ & 13.7961206 & -0.1087747 & 0.062522 & 30 & $\mathrm{C}$ & 13.8150452 & -0.1107847 & 0.0620959 \\
\hline 31 & $\mathrm{C}$ & 15.017583 & -0.1068174 & 0.0541474 & 31 & $\mathrm{C}$ & 15.036615 & -0.1099848 & 0.0575077 \\
\hline 32 & $\mathrm{Si}$ & 16.8498977 & -0.0366162 & 0.0146971 & 32 & $\mathrm{Si}$ & 16.8684124 & -0.0412679 & 0.0255965 \\
\hline 33 & $\mathrm{C}$ & 17.4829045 & -1.108509 & -1.4353216 & 33 & $\mathrm{C}$ & 17.5094136 & -1.1251842 & -1.4121681 \\
\hline 34 & $\mathrm{C}$ & 18.8707229 & -0.6539659 & -1.9247197 & 34 & $\mathrm{C}$ & 18.8992573 & -0.6741867 & -1.8990112 \\
\hline 35 & $\mathrm{C}$ & 16.4912086 & -1.1943733 & -2.6082866 & 35 & $\mathrm{C}$ & 16.5232127 & -1.2216025 & -2.5888979 \\
\hline 36 & $\mathrm{C}$ & 17.3159676 & 1.7989054 & -0.1861564 & 36 & $\mathrm{C}$ & 17.3374187 & 1.7921968 & -0.1881271 \\
\hline 37 & $\mathrm{C}$ & 17.4731916 & -0.7128125 & 1.6823774 & 37 & $\mathrm{C}$ & 17.4849061 & -0.703975 & 1.7013853 \\
\hline 38 & $\mathrm{C}$ & 19.0044935 & -0.6483483 & 1.8108016 & 38 & $\mathrm{C}$ & 19.0157865 & -0.6410742 & 1.8350313 \\
\hline
\end{tabular}




\begin{tabular}{|c|c|c|c|c|c|c|c|c|c|}
\hline 39 & $\mathrm{C}$ & 16.9527461 & -2.1341301 & 1.9531586 & 39 & $\mathrm{C}$ & 16.960943 & -2.121965 & 1.9825233 \\
\hline 40 & $\mathrm{C}$ & 16.6945964 & 2.4098328 & -1.4541475 & 40 & $\mathrm{C}$ & 16.7234108 & 2.3930608 & -1.4644859 \\
\hline 41 & $\mathrm{C}$ & 16.9201609 & 2.6132861 & 1.0575238 & 41 & $\mathrm{C}$ & 16.9353167 & 2.6172776 & 1.0464508 \\
\hline 42 & $\mathrm{C}$ & 8.3848529 & -5.7647883 & -0.969097 & 42 & $\mathrm{C}$ & 8.4004917 & -5.7775941 & -0.8785891 \\
\hline 43 & $\mathrm{C}$ & 8.3784378 & -7.1588568 & -0.9547657 & 43 & $\mathrm{C}$ & 8.3958763 & -7.1722801 & -0.8420935 \\
\hline 44 & $\mathrm{C}$ & 8.8908151 & -7.857994 & 0.1499911 & 44 & $\mathrm{C}$ & 8.8981636 & -7.8490026 & 0.2805775 \\
\hline 45 & $\mathrm{C}$ & 9.4071762 & -7.1388724 & 1.2395962 & 45 & $\mathrm{C}$ & 9.4079371 & -7.1085645 & 1.3590364 \\
\hline 46 & $\mathrm{C}$ & 9.4043367 & -5.7434966 & 1.2206944 & 46 & $\mathrm{C}$ & 9.4119533 & -5.7148315 & 1.3141587 \\
\hline 47 & $\mathrm{C}$ & 9.4926603 & 6.962293 & -1.1299897 & 47 & $\mathrm{C}$ & 9.5184837 & 6.9396625 & -1.2642013 \\
\hline 48 & $\mathrm{C}$ & 8.9703289 & 7.6857417 & -0.0461703 & 48 & $\mathrm{C}$ & 8.9956266 & 7.6824768 & -0.1939537 \\
\hline 49 & $\mathrm{C}$ & 8.4374835 & 6.9911121 & 1.0516134 & 49 & $\mathrm{C}$ & 8.4613745 & 7.0077768 & 0.9154083 \\
\hline 50 & $\mathrm{C}$ & 8.4287347 & 5.5970145 & 1.0643058 & 50 & $\mathrm{C}$ & 8.4505548 & 5.6140731 & 0.9519588 \\
\hline 51 & $\mathrm{H}$ & 4.3841175 & 2.5701296 & -0.1131066 & 51 & $\mathrm{H}$ & 4.4082895 & 2.5766967 & -0.1957438 \\
\hline 52 & $\mathrm{H}$ & 4.3564333 & -2.6977437 & 0.1517542 & 52 & $\mathrm{H}$ & 4.3742322 & -2.6913083 & 0.191715 \\
\hline 53 & $\mathrm{H}$ & 11.6126344 & 4.4588898 & 0.1155269 & 53 & $\mathrm{H}$ & 11.6346544 & 4.4589058 & 0.0320868 \\
\hline 54 & $\mathrm{H}$ & 13.4980047 & 2.5308799 & 0.1357825 & 54 & $\mathrm{H}$ & 13.5182755 & 2.5301294 & 0.0899038 \\
\hline 55 & $\mathrm{H}$ & 6.2894004 & 4.4829419 & -0.1423539 & 55 & $\mathrm{H}$ & 6.3175579 & 4.4826067 & -0.2502003 \\
\hline 56 & $\mathrm{H}$ & 6.2422881 & -4.6289136 & 0.2091214 & 56 & $\mathrm{H}$ & 6.2600491 & -4.6188709 & 0.2817476 \\
\hline 57 & $\mathrm{H}$ & 13.4729666 & -2.7449828 & 0.0081004 & 57 & $\mathrm{H}$ & 13.4880399 & -2.7473508 & 0.0506476 \\
\hline 58 & $\mathrm{H}$ & 11.5682172 & -4.6571719 & 0.0128926 & 58 & $\mathrm{H}$ & 11.5809097 & -4.6568044 & 0.0850854 \\
\hline 59 & $\mathrm{H}$ & 17.5919661 & -2.1222765 & -1.0209405 & 59 & $\mathrm{H}$ & 17.6171076 & -2.1353331 & -0.9886171 \\
\hline 60 & $\mathrm{H}$ & 19.6096229 & -0.6207156 & -1.1165964 & 60 & $\mathrm{H}$ & 19.634337 & -0.6335123 & -1.087744 \\
\hline 61 & $\mathrm{H}$ & 18.826612 & 0.3464567 & -2.3710411 & 61 & $\mathrm{H}$ & 18.8567144 & 0.3223393 & -2.3541205 \\
\hline 62 & $\mathrm{H}$ & 19.2537159 & -1.3361431 & -2.6951898 & 62 & $\mathrm{H}$ & 19.2862576 & -1.3627376 & -2.6618078 \\
\hline 63 & $\mathrm{H}$ & 15.5144475 & -1.5685573 & -2.28668 & 63 & $\mathrm{H}$ & 15.5450768 & -1.5931092 & -2.2684221 \\
\hline 64 & $\mathrm{H}$ & 16.8734677 & -1.8619867 & -3.3922092 & 64 & $\mathrm{H}$ & 16.9091824 & -1.8958499 & -3.3653313 \\
\hline 65 & $\mathrm{H}$ & 16.326939 & -0.2122183 & -3.0668016 & 65 & $\mathrm{H}$ & 16.3607792 & -0.2434585 & -3.0565648 \\
\hline 66 & $\mathrm{H}$ & 18.4108467 & 1.8399803 & -0.2872559 & 66 & $\mathrm{H}$ & 18.4328778 & 1.8316588 & -0.2835629 \\
\hline 67 & $\mathrm{H}$ & 17.0394582 & -0.0491248 & 2.4444738 & 67 & $\mathrm{H}$ & 17.0494443 & -0.0330725 & 2.4561388 \\
\hline 68 & $\mathrm{H}$ & 19.3921854 & 0.3631659 & 1.6407906 & 68 & $\mathrm{H}$ & 19.4058254 & 0.368288 & 1.6577037 \\
\hline 69 & $\mathrm{H}$ & 19.4915843 & -1.3162247 & 1.0898684 & 69 & $\mathrm{H}$ & 19.5043856 & -1.3159337 & 1.1216382 \\
\hline 70 & $\mathrm{H}$ & 19.3286526 & -0.9631689 & 2.8116131 & 70 & $\mathrm{H}$ & 19.3358178 & -0.9478033 & 2.8397102 \\
\hline
\end{tabular}




\begin{tabular}{|c|c|c|c|c|c|c|c|c|c|}
\hline 71 & $\mathrm{H}$ & 15.8590226 & -2.1774516 & 1.9076332 & 71 & $\mathrm{H}$ & 15.8673066 & -2.1635165 & 1.9335062 \\
\hline 72 & $\mathrm{H}$ & 17.2631326 & -2.4845888 & 2.94652 & 72 & $\mathrm{H}$ & 17.267246 & -2.464612 & 2.9799078 \\
\hline 73 & $\mathrm{H}$ & 17.34646 & -2.8502863 & 1.2206279 & 73 & $\mathrm{H}$ & 17.3557899 & -2.8450524 & 1.2574284 \\
\hline 74 & $\mathrm{H}$ & 15.6004586 & 2.3415477 & -1.4282225 & 74 & $\mathrm{H}$ & 15.629132 & 2.3252521 & -1.4441191 \\
\hline 75 & $\mathrm{H}$ & 17.0324649 & 1.9025801 & -2.3641755 & 75 & $\mathrm{H}$ & 17.0661353 & 1.8783897 & -2.3685316 \\
\hline 76 & $\mathrm{H}$ & 16.9591956 & 3.4715215 & -1.548353 & 76 & $\mathrm{H}$ & 16.9888811 & 3.4539052 & -1.5658205 \\
\hline 77 & $\mathrm{H}$ & 17.4316469 & 2.2618823 & 1.9604138 & 77 & $\mathrm{H}$ & 17.4414351 & 2.2729979 & 1.9551126 \\
\hline 78 & $\mathrm{H}$ & 15.8407991 & 2.5496419 & 1.2443131 & 78 & $\mathrm{H}$ & 15.8548819 & 2.5559046 & 1.2276059 \\
\hline 79 & $\mathrm{H}$ & 17.1693498 & 3.6747483 & 0.9265835 & 79 & $\mathrm{H}$ & 17.18612 & 3.6774493 & 0.9081078 \\
\hline 80 & $\mathrm{H}$ & 7.9960501 & -5.2517588 & -1.8416815 & 80 & $\mathrm{H}$ & 8.0180252 & -5.2804182 & -1.763077 \\
\hline 81 & $\mathrm{O}$ & 7.9283227 & -7.8314579 & -2.064799 & 81 & $\mathrm{O}$ & 7.9607535 & -7.8594868 & -1.9469226 \\
\hline 82 & $\mathrm{O}$ & 8.8996997 & -9.2347798 & 0.1650878 & 82 & $\mathrm{O}$ & 8.9013083 & -9.2258032 & 0.3129976 \\
\hline 83 & $\mathrm{O}$ & 9.9765663 & -7.7804875 & 2.3094783 & 83 & $\mathrm{O}$ & 9.9643462 & -7.7381578 & 2.4455141 \\
\hline 84 & $\mathrm{H}$ & 9.8059385 & -5.2129193 & 2.0768766 & 84 & $\mathrm{H}$ & 9.8101688 & -5.1683899 & 2.1619114 \\
\hline 85 & $\mathrm{O}$ & 10.082521 & 7.5994144 & -2.1915268 & 85 & $\mathrm{O}$ & 10.1106199 & 7.5584974 & -2.3356035 \\
\hline 86 & $\mathrm{O}$ & 8.9939979 & 9.0625102 & -0.0588223 & 86 & $\mathrm{O}$ & 9.0209722 & 9.0590445 & -0.2294887 \\
\hline 87 & $\mathrm{O}$ & 7.9820559 & 7.6672937 & 2.1573556 & 87 & $\mathrm{O}$ & 8.0073246 & 7.7034187 & 2.0097113 \\
\hline 88 & $\mathrm{H}$ & 8.0242633 & 5.0871679 & 1.9316158 & 88 & $\mathrm{H}$ & 8.0449647 & 5.1196578 & 1.8276503 \\
\hline 89 & $\mathrm{C}$ & 9.4749152 & 5.5670643 & -1.1127781 & 89 & $\mathrm{C}$ & 9.4992705 & 5.5450232 & -1.2228834 \\
\hline 90 & $\mathrm{H}$ & 9.8816328 & 5.0330924 & -1.9644145 & 90 & $\mathrm{H}$ & 9.9068202 & 4.9957103 & -2.0642977 \\
\hline 91 & $\mathrm{C}$ & 1.4542991 & -0.0431811 & -0.0072559 & 91 & $\mathrm{C}$ & 1.4433381 & -0.0315408 & -0.0294504 \\
\hline 92 & $\mathrm{C}$ & -1.3958836 & -0.0194735 & -0.0328994 & 92 & $\mathrm{C}$ & -1.3857749 & -0.0013173 & -0.0533284 \\
\hline 93 & $\mathrm{C}$ & 0.7103233 & -1.2386798 & 0.0261562 & 93 & $\mathrm{C}$ & 0.7082125 & -1.2370853 & -0.0369722 \\
\hline 94 & $\mathrm{C}$ & -0.6727284 & -1.2273267 & 0.0133239 & 94 & $\mathrm{C}$ & -0.6765589 & -1.2223574 & -0.0489417 \\
\hline 95 & $\mathrm{C}$ & -0.6517211 & 1.1760053 & -0.0658308 & 95 & $\mathrm{C}$ & -0.6505396 & 1.204249 & -0.0461768 \\
\hline 96 & $\mathrm{C}$ & 0.731075 & 1.1645498 & -0.053844 & 96 & $\mathrm{C}$ & 0.7341114 & 1.1894793 & -0.0347314 \\
\hline 97 & $\mathrm{~F}$ & 1.4000951 & 2.3268871 & -0.0873927 & 97 & $\mathrm{C}$ & -2.8015209 & 0.0146012 & -0.0638259 \\
\hline 98 & $\mathrm{~F}$ & -1.3004592 & 2.3495423 & -0.1102106 & 98 & $\mathrm{C}$ & -4.0197505 & 0.0294128 & -0.0718433 \\
\hline 99 & $\mathrm{~F}$ & 1.3594076 & -2.4114513 & 0.072021 & 99 & $\mathrm{C}$ & -7.6057215 & 2.8918954 & -0.0105897 \\
\hline 100 & $\mathrm{~F}$ & -1.341725 & -2.3889423 & 0.0465554 & 100 & C & -6.318908 & 3.5492805 & -0.0587099 \\
\hline 101 & $\mathrm{C}$ & -2.8008334 & -0.006387 & -0.0449218 & 101 & $\mathrm{C}$ & -5.3714797 & 2.5693183 & -0.0822986 \\
\hline 102 & $\mathrm{C}$ & -4.0169305 & 0.0093192 & -0.0557193 & 102 & $\mathrm{C}$ & -6.0728278 & 1.310926 & -0.061883 \\
\hline
\end{tabular}




\begin{tabular}{|c|c|c|c|c|c|c|c|c|c|}
\hline 103 & $\mathrm{C}$ & -7.5759112 & 2.8900532 & -0.0602879 & 103 & $\mathrm{~N}$ & -7.425485 & 1.5242206 & -0.0244792 \\
\hline 104 & $\mathrm{C}$ & -6.2831978 & 3.5378847 & -0.1157556 & 104 & $\mathrm{C}$ & -5.4373641 & 0.0485253 & -0.0789416 \\
\hline 105 & $\mathrm{C}$ & -5.3408124 & 2.5529311 & -0.1155568 & 105 & $\mathrm{C}$ & -8.8409134 & 3.5597266 & 0.0284246 \\
\hline 106 & $\mathrm{C}$ & -6.0544247 & 1.3002904 & -0.0743759 & 106 & $\mathrm{C}$ & -11.666474 & 1.3859434 & -0.0139525 \\
\hline 107 & $\mathrm{~N}$ & -7.4040631 & 1.5204148 & -0.0466698 & 107 & $\mathrm{C}$ & -12.33572 & 2.6593785 & 0.0856363 \\
\hline 108 & $\mathrm{C}$ & -5.4304761 & 0.033008 & -0.0663627 & 108 & $\mathrm{C}$ & -11.363322 & 3.613435 & 0.1178169 \\
\hline 109 & $\mathrm{C}$ & -8.807301 & 3.5625107 & -0.0385555 & 109 & $\mathrm{C}$ & -10.093554 & 2.9259745 & 0.026142 \\
\hline 110 & $\mathrm{C}$ & -11.641946 & 1.3969589 & -0.0405727 & 110 & $\mathrm{~N}$ & -10.308179 & 1.5653426 & -0.043359 \\
\hline 111 & C & -12.306495 & 2.6740784 & 0.0334322 & 111 & $\mathrm{C}$ & -12.333062 & 0.1445596 & -0.0736095 \\
\hline 112 & $\mathrm{C}$ & -11.330333 & 3.6251909 & 0.0473628 & 112 & $\mathrm{C}$ & -10.170179 & -2.6971041 & -0.2049367 \\
\hline 113 & C & -10.063358 & 2.9315414 & -0.0298934 & 113 & $\mathrm{C}$ & -11.458493 & -3.3481989 & -0.2993727 \\
\hline 114 & $\mathrm{~N}$ & -10.282585 & 1.5711659 & -0.0726504 & 114 & $\mathrm{C}$ & -12.405418 & -2.3686582 & -0.2536803 \\
\hline 115 & C & -12.312446 & 0.1566838 & -0.0762901 & 115 & $\mathrm{C}$ & -11.701105 & -1.1150328 & -0.145051 \\
\hline 116 & C & -10.16228 & -2.6964739 & -0.1493579 & 116 & $\mathrm{~N}$ & -10.348313 & -1.3321062 & -0.1234221 \\
\hline 117 & C & -11.45289 & -3.3436209 & -0.2337897 & 117 & $\mathrm{C}$ & -8.9352753 & -3.3659341 & -0.211031 \\
\hline 118 & C & -12.395925 & -2.3591759 & -0.2082513 & 118 & $\mathrm{C}$ & -6.1074725 & -1.1955593 & -0.1032456 \\
\hline 119 & $\mathrm{C}$ & -11.686489 & -1.1071735 & -0.1221998 & 119 & $\mathrm{C}$ & -5.4408942 & -2.4730453 & -0.0886368 \\
\hline 120 & $\mathrm{~N}$ & -10.334316 & -1.3299994 & -0.0939176 & 120 & $\mathrm{C}$ & -6.4141509 & -3.4265592 & -0.1217056 \\
\hline 121 & C & -8.9293565 & -3.3725338 & -0.1410146 & 121 & $\mathrm{C}$ & -7.6822771 & -2.7334439 & -0.1684201 \\
\hline 122 & C & -6.0991476 & -1.2110209 & -0.0698006 & 122 & $\mathrm{~N}$ & -7.4654683 & -1.3708341 & -0.1454839 \\
\hline 123 & C & -5.4307181 & -2.4886771 & -0.0323683 & 123 & $\mathrm{Zn}$ & -8.8875113 & 0.0967069 & -0.0864818 \\
\hline 124 & $\mathrm{C}$ & -6.4067336 & -3.4397309 & -0.0492299 & 124 & $\mathrm{C}$ & -8.9582844 & -4.8579307 & -0.2580067 \\
\hline 125 & C & -7.6750735 & -2.7454902 & -0.1089246 & 125 & $\mathrm{C}$ & -8.8184988 & 5.0515236 & 0.0836501 \\
\hline 126 & $\mathrm{~N}$ & -7.4555496 & -1.3822657 & -0.1101641 & 126 & $\mathrm{C}$ & -13.755623 & 0.1587502 & -0.0588382 \\
\hline 127 & $\mathrm{Zn}$ & -8.869253 & 0.0948272 & -0.0831564 & 127 & $\mathrm{C}$ & -14.977126 & 0.1551115 & -0.0453333 \\
\hline 128 & $\mathrm{C}$ & -8.96009 & -4.8648724 & -0.1608107 & 128 & $\mathrm{Si}$ & -16.811281 & 0.1125802 & 0.0025966 \\
\hline 129 & $\mathrm{C}$ & -8.7804994 & 5.0548628 & -0.015004 & 129 & $\mathrm{C}$ & -17.37218 & 1.9206787 & -0.2209285 \\
\hline 130 & $\mathrm{C}$ & -13.735031 & 0.1766744 & -0.0632704 & 130 & $\mathrm{C}$ & -17.397859 & -0.9576658 & -1.4683956 \\
\hline 131 & $\mathrm{C}$ & -14.956463 & 0.1773029 & -0.0508168 & 131 & $\mathrm{C}$ & -17.252513 & -0.5816517 & 1.7242813 \\
\hline 132 & $\mathrm{Si}$ & -16.791432 & 0.1392213 & -0.0035133 & 132 & $\mathrm{C}$ & -16.754904 & -2.0274569 & 1.8977822 \\
\hline 133 & $\mathrm{C}$ & -17.347825 & 1.9463741 & -0.2438713 & 133 & $\mathrm{C}$ & -18.73299 & -0.4534251 & 2.1223755 \\
\hline 134 & $\mathrm{C}$ & -17.378341 & -0.943737 & -1.4648155 & 134 & $\mathrm{C}$ & -16.429173 & -2.1062931 & -1.8027429 \\
\hline
\end{tabular}




\begin{tabular}{|c|c|c|c|c|c|c|c|c|c|}
\hline 135 & $\mathrm{C}$ & -17.233199 & -0.5384756 & 1.7245145 & 135 & $\mathrm{C}$ & -18.831501 & -1.4944467 & -1.3047279 \\
\hline 136 & $\mathrm{C}$ & -16.738336 & -1.983599 & 1.9111781 & 136 & $\mathrm{C}$ & -16.997273 & 2.7775554 & 1.000369 \\
\hline 137 & $\mathrm{C}$ & -18.713585 & -0.4040117 & 2.1210624 & 137 & $\mathrm{C}$ & -18.854014 & 2.0934515 & -0.594368 \\
\hline 138 & $\mathrm{C}$ & -16.411807 & -2.0976321 & -1.7871198 & 138 & C & -8.2712349 & 5.7006515 & 1.2022122 \\
\hline 139 & $\mathrm{C}$ & -18.813271 & -1.4758911 & -1.2970096 & 139 & $\mathrm{C}$ & -8.252338 & 7.0927643 & 1.2599252 \\
\hline 140 & $\mathrm{C}$ & -16.970809 & 2.8134575 & 0.9695538 & 140 & $\mathrm{C}$ & -8.7644189 & 7.8677126 & 0.1937121 \\
\hline 141 & $\mathrm{C}$ & -18.829396 & 2.1187763 & -0.618633 & 141 & $\mathrm{C}$ & -9.3024868 & 7.2105113 & -0.9242397 \\
\hline 142 & $\mathrm{C}$ & -8.226583 & 5.7259949 & 1.0871412 & 142 & $\mathrm{C}$ & -9.3298548 & 5.8086322 & -0.9657846 \\
\hline 143 & $\mathrm{C}$ & -8.201854 & 7.1190045 & 1.1142473 & 143 & C & -8.4435349 & -5.5423678 & -1.3547288 \\
\hline 144 & $\mathrm{C}$ & -8.7151274 & 7.8723756 & 0.0332101 & 144 & $\mathrm{C}$ & -8.4733461 & -6.94369 & -1.4092219 \\
\hline 145 & $\mathrm{C}$ & -9.2602474 & 7.1929951 & -1.0680078 & 145 & C & -9.017232 & -7.6749999 & -0.3412073 \\
\hline 146 & $\mathrm{C}$ & -9.2933033 & 5.7907341 & -1.0788282 & 146 & C & -9.5327997 & -6.9739849 & 0.7733788 \\
\hline 147 & $\mathrm{C}$ & -8.4466308 & -5.5711371 & -1.2440222 & 147 & C & -9.5112118 & -5.581232 & 0.8111534 \\
\hline 148 & $\mathrm{C}$ & -8.4835071 & -6.973222 & -1.2738569 & 148 & $\mathrm{H}$ & -4.369853 & -2.6080621 & -0.0503908 \\
\hline 149 & $\mathrm{C}$ & -9.0331543 & -7.6823398 & -0.1938626 & 149 & $\mathrm{H}$ & -4.2970431 & 2.6740499 & -0.1218081 \\
\hline 150 & $\mathrm{C}$ & -9.546996 & -6.9588007 & 0.9071978 & 150 & $\mathrm{H}$ & -6.1692319 & 4.6181141 & -0.0801869 \\
\hline 151 & $\mathrm{C}$ & -9.5188425 & -5.5657726 & 0.9202314 & 151 & $\mathrm{H}$ & -13.407538 & 2.789163 & 0.1290499 \\
\hline 152 & $\mathrm{H}$ & -4.3587896 & -2.6233494 & 0.0076857 & 152 & $\mathrm{H}$ & -11.485115 & 4.682921 & 0.1987246 \\
\hline 153 & $\mathrm{H}$ & -4.2645043 & 2.6488931 & -0.1497578 & 153 & $\mathrm{H}$ & -11.609249 & -4.412677 & -0.396544 \\
\hline 154 & $\mathrm{H}$ & -6.1265274 & 4.605084 & -0.1574485 & 154 & $\mathrm{H}$ & -13.480132 & -2.4689825 & -0.3019929 \\
\hline 155 & $\mathrm{H}$ & -13.377802 & 2.8088591 & 0.0738447 & 155 & $\mathrm{H}$ & -6.2931756 & -4.4991329 & -0.1124315 \\
\hline 156 & $\mathrm{H}$ & -11.44829 & 4.6964497 & 0.1072661 & 156 & $\mathrm{H}$ & -16.774395 & 2.279004 & -1.0731637 \\
\hline 157 & $\mathrm{H}$ & -11.608021 & -4.4090694 & -0.3110239 & 157 & $\mathrm{H}$ & -17.395686 & -0.2654054 & -2.3252131 \\
\hline 158 & $\mathrm{H}$ & -13.47093 & -2.456024 & -0.2568751 & 158 & $\mathrm{H}$ & -16.669925 & 0.0487744 & 2.4129405 \\
\hline 159 & $\mathrm{H}$ & -6.2878578 & -4.5122172 & -0.0211326 & 159 & $\mathrm{H}$ & -16.889376 & -2.3657681 & 2.9339847 \\
\hline 160 & $\mathrm{H}$ & -16.749454 & 2.2955347 & -1.0995061 & 160 & $\mathrm{H}$ & -15.691662 & -2.1208033 & 1.6500353 \\
\hline 161 & $\mathrm{H}$ & -17.374064 & -0.2597313 & -2.328209 & 161 & $\mathrm{H}$ & -17.310996 & -2.7213618 & 1.256099 \\
\hline 162 & $\mathrm{H}$ & -16.649678 & 0.097196 & 2.4075372 & 162 & $\mathrm{H}$ & -19.385974 & -1.0285516 & 1.4574478 \\
\hline 163 & $\mathrm{H}$ & -16.874208 & -2.3123581 & 2.9502385 & 163 & $\mathrm{H}$ & -19.074662 & 0.5867579 & 2.1037375 \\
\hline 164 & $\mathrm{H}$ & -15.675066 & -2.0812456 & 1.6651728 & 164 & $\mathrm{H}$ & -18.891858 & -0.8324825 & 3.14105 \\
\hline 165 & $\mathrm{H}$ & -17.295249 & -2.6821147 & 1.2752655 & 165 & $\mathrm{H}$ & -16.369838 & -2.8292346 & -0.9801735 \\
\hline 166 & $\mathrm{H}$ & -19.367445 & -0.983917 & 1.4611707 & 166 & $\mathrm{H}$ & -15.416402 & -1.7388495 & -1.9935897 \\
\hline
\end{tabular}




\begin{tabular}{|c|c|c|c|c|c|c|c|c|c|}
\hline 167 & $\mathrm{H}$ & -19.053405 & 0.6365629 & 2.0931557 & 167 & $\mathrm{H}$ & -16.767514 & -2.6531716 & -2.6931486 \\
\hline 168 & $\mathrm{H}$ & -18.873223 & -0.7737041 & 3.1430238 & 168 & $\mathrm{H}$ & -19.554666 & -0.7041771 & -1.0775957 \\
\hline 169 & $\mathrm{H}$ & -16.354539 & -2.8125199 & -0.9574021 & 169 & $\mathrm{H}$ & -18.88549 & -2.2337682 & -0.4974591 \\
\hline 170 & $\mathrm{H}$ & -15.398116 & -1.7343538 & -1.9810699 & 170 & $\mathrm{H}$ & -19.164994 & -1.9948078 & -2.2236242 \\
\hline 171 & $\mathrm{H}$ & -16.750812 & -2.6525378 & -2.6722521 & 171 & $\mathrm{H}$ & -15.933439 & 2.6853828 & 1.248493 \\
\hline 172 & $\mathrm{H}$ & -19.534929 & -0.6819882 & -1.0779286 & 172 & $\mathrm{H}$ & -17.570194 & 2.4812224 & 1.8875061 \\
\hline 173 & $\mathrm{H}$ & -18.86936 & -2.2074282 & -0.4828314 & 173 & $\mathrm{H}$ & -17.207982 & 3.8394232 & 0.8166698 \\
\hline 174 & $\mathrm{H}$ & -19.147107 & -1.9841978 & -2.2113747 & 174 & $\mathrm{H}$ & -19.520028 & 1.7211279 & 0.1924584 \\
\hline 175 & $\mathrm{H}$ & -15.907048 & 2.721588 & 1.2181466 & 175 & $\mathrm{H}$ & -19.105755 & 1.564164 & -1.5198297 \\
\hline 176 & $\mathrm{H}$ & -17.543956 & 2.5261495 & 1.8594842 & 176 & $\mathrm{H}$ & -19.094253 & 3.1542721 & -0.7464696 \\
\hline 177 & $\mathrm{H}$ & -17.17962 & 3.8739876 & 0.776362 & 177 & $\mathrm{H}$ & -7.8884024 & 5.1036588 & 2.0193771 \\
\hline 178 & $\mathrm{H}$ & -19.496003 & 1.754812 & 0.1715807 & 178 & $\mathrm{O}$ & -7.7849275 & 7.8059998 & 2.3264673 \\
\hline 179 & $\mathrm{H}$ & -19.082363 & 1.5818464 & -1.539344 & 179 & $\mathrm{O}$ & -8.825629 & 9.2373554 & 0.2876771 \\
\hline 180 & $\mathrm{H}$ & -19.06743 & 3.1786813 & -0.7800908 & 180 & $\mathrm{O}$ & -9.8700256 & 7.831979 & -1.9965492 \\
\hline 181 & $\mathrm{H}$ & -7.8430656 & 5.1456882 & 1.9158916 & 181 & $\mathrm{H}$ & -9.7447144 & 5.3328952 & -1.8468695 \\
\hline 182 & $\mathrm{O}$ & -7.7274846 & 7.8533285 & 2.1628973 & 182 & $\mathrm{H}$ & -8.0247167 & -5.0082699 & -2.1997597 \\
\hline 183 & $\mathrm{O}$ & -8.770316 & 9.2437724 & 0.0966847 & 183 & $\mathrm{O}$ & -7.9023779 & -7.4921231 & -2.5190249 \\
\hline 184 & $\mathrm{O}$ & -9.8292641 & 7.7933905 & -2.1513568 & 184 & $\mathrm{O}$ & -8.9584877 & -9.0478994 & -0.3416135 \\
\hline 185 & $\mathrm{H}$ & -9.7127413 & 5.2976563 & -1.9481311 & 185 & $\mathrm{O}$ & -10.006099 & -7.7574475 & 1.7866631 \\
\hline 186 & $\mathrm{H}$ & -8.0234073 & -5.0543888 & -2.0975922 & 186 & $\mathrm{H}$ & -9.8967356 & -5.0408459 & 1.665564 \\
\hline 187 & $\mathrm{O}$ & -7.9135742 & -7.5425146 & -2.3731407 & 187 & $\mathrm{C}$ & 6.8262098 & 8.4782973 & 1.7840411 \\
\hline 188 & $\mathrm{O}$ & -8.9818523 & -9.0551977 & -0.1687929 & 188 & $\mathrm{C}$ & 10.1488711 & 9.6171282 & 0.4548186 \\
\hline 189 & $\mathrm{O}$ & -10.025771 & -7.7218043 & 1.9332387 & 189 & $\mathrm{C}$ & 9.2358379 & 8.3455764 & -3.14904 \\
\hline 190 & $\mathrm{H}$ & -9.9029774 & -5.0084455 & 1.7643282 & 190 & $\mathrm{C}$ & 9.0452655 & -8.4847085 & 3.2492486 \\
\hline 191 & $\mathrm{C}$ & 6.7970787 & 8.4406446 & 1.9447345 & 191 & $\mathrm{C}$ & 10.1502019 & -9.7936057 & -0.0987246 \\
\hline 192 & $\mathrm{C}$ & 10.1073844 & 9.6122632 & 0.6555054 & 192 & $\mathrm{C}$ & 6.7803119 & -8.6430578 & -1.751869 \\
\hline 193 & $\mathrm{C}$ & 9.207031 & 8.4023518 & -2.9887604 & 193 & $\mathrm{C}$ & -10.499058 & -7.1106481 & 2.9487183 \\
\hline 194 & $\mathrm{C}$ & 9.0830621 & -8.5748224 & 3.0952821 & 194 & $\mathrm{C}$ & -10.214428 & -9.7301474 & -0.3681724 \\
\hline 195 & $\mathrm{C}$ & 10.0055834 & -9.7987556 & -0.549865 & 195 & $\mathrm{C}$ & -8.4204009 & -8.6993808 & -3.072121 \\
\hline 196 & $\mathrm{C}$ & 6.7312575 & -8.58991 & -1.8650328 & 196 & $\mathrm{C}$ & -7.2999085 & 7.0821867 & 3.4456198 \\
\hline 197 & $\mathrm{C}$ & -10.514552 & -7.0524311 & 3.0842386 & 197 & $\mathrm{C}$ & -7.5708075 & 9.921509 & 0.3125234 \\
\hline 198 & $\mathrm{C}$ & -10.2413 & -9.7312111 & -0.1866663 & 198 & $\mathrm{C}$ & -9.3578079 & 9.0785731 & -2.4604878 \\
\hline
\end{tabular}




\begin{tabular}{|c|c|c|c|c|c|c|c|c|c|}
\hline 199 & $\mathrm{C}$ & -8.4252137 & -8.7642032 & -2.8999238 & 199 & $\mathrm{H}$ & 5.9937363 & 7.830039 & 1.4801165 \\
\hline 200 & $\mathrm{C}$ & -7.233791 & 7.1523253 & 3.2929131 & 200 & $\mathrm{H}$ & 6.9943614 & 9.2439012 & 1.0212383 \\
\hline 201 & $\mathrm{C}$ & -7.5125232 & 9.9233926 & 0.1025311 & 201 & $\mathrm{H}$ & 6.5868816 & 8.9501775 & 2.739372 \\
\hline 202 & $\mathrm{C}$ & -9.3109662 & 9.0257173 & -2.6461408 & 202 & $\mathrm{H}$ & 11.0834186 & 9.2806524 & -0.0089951 \\
\hline 203 & $\mathrm{H}$ & 5.9672519 & 7.793455 & 1.631858 & 203 & $\mathrm{H}$ & 10.1347786 & 9.3361036 & 1.513591 \\
\hline 204 & $\mathrm{H}$ & 6.9612954 & 9.2184418 & 1.1934679 & 204 & $\mathrm{H}$ & 10.0603328 & 10.7014571 & 0.358853 \\
\hline 205 & $\mathrm{H}$ & 6.5569594 & 8.8968606 & 2.9073947 & 205 & $\mathrm{H}$ & 8.8001284 & 9.1707201 & -2.5790592 \\
\hline 206 & $\mathrm{H}$ & 11.0513189 & 9.2854991 & 0.2038248 & 206 & $\mathrm{H}$ & 8.4359007 & 7.7214941 & -3.5685721 \\
\hline 207 & $\mathrm{H}$ & 10.0743906 & 9.3144243 & 1.7091413 & 207 & $\mathrm{H}$ & 9.8516471 & 8.7379433 & -3.9611191 \\
\hline 208 & $\mathrm{H}$ & 10.0176673 & 10.6977157 & 0.5748665 & 208 & $\mathrm{H}$ & 8.5802391 & -9.2904098 & 2.6741951 \\
\hline 209 & $\mathrm{H}$ & 8.7747671 & 9.2184085 & -2.4033843 & 209 & $\mathrm{H}$ & 8.2684747 & -7.8248999 & 3.6569848 \\
\hline 210 & $\mathrm{H}$ & 8.404607 & 7.7872645 & -3.416676 & 210 & $\mathrm{H}$ & 9.6323315 & -8.9029706 & 4.0695943 \\
\hline 211 & $\mathrm{H}$ & 9.8215035 & 8.8072909 & -3.795646 & 211 & $\mathrm{H}$ & 10.0312536 & -10.877276 & -0.033014 \\
\hline 212 & $\mathrm{H}$ & 8.6516762 & -9.3875996 & 2.5047792 & 212 & $\mathrm{H}$ & 10.9586479 & -9.4685756 & 0.5654595 \\
\hline 213 & $\mathrm{H}$ & 8.2802983 & -7.9522013 & 3.5115276 & 213 & $\mathrm{H}$ & 10.3781729 & -9.5091711 & -1.1325175 \\
\hline 214 & $\mathrm{H}$ & 9.6827664 & -8.984338 & 3.9109296 & 214 & $\mathrm{H}$ & 5.9404307 & -8.0042949 & -1.4477548 \\
\hline 215 & $\mathrm{H}$ & 9.9034281 & -10.882899 & -0.4666632 & 215 & $\mathrm{H}$ & 6.9413533 & -9.4226297 & -1.0021491 \\
\hline 216 & $\mathrm{H}$ & 10.9538824 & -9.4819797 & -0.1001373 & 216 & $\mathrm{H}$ & 6.5564186 & -9.0972463 & -2.7194479 \\
\hline 217 & $\mathrm{H}$ & 9.9745764 & -9.5027748 & -1.6040077 & 217 & $\mathrm{H}$ & -9.7194219 & -6.5079995 & 3.4313715 \\
\hline 218 & $\mathrm{H}$ & 5.9058624 & -7.9318887 & -1.5634656 & 218 & $\mathrm{H}$ & -10.811646 & -7.9088157 & 3.6238912 \\
\hline 219 & $\mathrm{H}$ & 6.8768502 & -9.3680816 & -1.1103034 & 219 & $\mathrm{H}$ & -11.35903 & -6.4685564 & 2.7181443 \\
\hline 220 & $\mathrm{H}$ & 6.4972075 & -9.0450744 & -2.8296347 & 220 & $\mathrm{H}$ & -10.797279 & -9.439931 & -1.2526109 \\
\hline 221 & $\mathrm{H}$ & -9.7313039 & -6.4459225 & 3.5560546 & 221 & $\mathrm{H}$ & -10.794522 & -9.5276365 & 0.535086 \\
\hline 222 & $\mathrm{H}$ & -10.831129 & -7.8371599 & 3.7731427 & 222 & $\mathrm{H}$ & -9.9768805 & -10.794748 & -0.4250297 \\
\hline 223 & $\mathrm{H}$ & -11.371183 & -6.4097406 & 2.8430587 & 223 & $\mathrm{H}$ & -9.5170844 & -8.6805132 & -3.1019455 \\
\hline 224 & $\mathrm{H}$ & -10.819562 & -9.4549341 & -1.0785638 & 224 & $\mathrm{H}$ & -8.0881393 & -9.5765912 & -2.5138728 \\
\hline 225 & $\mathrm{H}$ & -10.823359 & -9.5083865 & 0.710532 & 225 & $\mathrm{H}$ & -8.0367626 & -8.7385229 & -4.0946217 \\
\hline 226 & $\mathrm{H}$ & -10.009196 & -10.797913 & -0.222272 & 226 & $\mathrm{H}$ & -8.0825003 & 6.4478793 & 3.8805447 \\
\hline 227 & $\mathrm{H}$ & -9.5218779 & -8.7508935 & -2.9325595 & 227 & $\mathrm{H}$ & -6.992972 & 7.8328871 & 4.1756109 \\
\hline 228 & $\mathrm{H}$ & -8.0902778 & -9.6271774 & -2.3215457 & 228 & $\mathrm{H}$ & -6.4376726 & 6.4574928 & 3.1785128 \\
\hline 229 & $\mathrm{H}$ & -8.0389728 & -8.8241627 & -3.9203931 & 229 & $\mathrm{H}$ & -7.8098528 & 10.9871372 & 0.3307847 \\
\hline 230 & $\mathrm{H}$ & -8.0137769 & 6.5292403 & 3.7482831 & 230 & $\mathrm{H}$ & -6.9854944 & 9.6956255 & -0.5889426 \\
\hline
\end{tabular}




\begin{tabular}{|ccccc|ccccc|}
231 & $\mathrm{H}$ & -6.9188884 & 7.9177556 & 4.0039215 & 231 & $\mathrm{H}$ & -6.9923916 & 9.6562413 & 1.2005177 \\
232 & $\mathrm{H}$ & -6.37522 & 6.5204172 & 3.0312648 & 232 & $\mathrm{H}$ & -8.2608998 & 9.0690847 & -2.4863152 \\
233 & $\mathrm{H}$ & -7.7474908 & 10.9900377 & 0.096173 & 233 & $\mathrm{H}$ & -9.698511 & 9.9120593 & -1.8434509 \\
234 & $\mathrm{H}$ & -6.9303772 & 9.6738548 & -0.7946572 & 234 & $\mathrm{H}$ & -9.7372871 & 9.1871566 & -3.4795163 \\
235 & $\mathrm{H}$ & -6.9331224 & 9.6767808 & 0.9951772 & 235 & $\mathrm{H}$ & -1.186046 & 2.1481732 & -0.0497903 \\
236 & $\mathrm{H}$ & -8.214292 & 9.0084844 & -2.6758757 & 236 & $\mathrm{H}$ & 1.2896782 & 2.1217244 & -0.0287113 \\
237 & $\mathrm{H}$ & -9.6440371 & 9.8753332 & -2.0472243 & 237 & $\mathrm{H}$ & 1.243543 & -2.1810765 & -0.0344017 \\
238 & $\mathrm{H}$ & -9.6937982 & 9.1130546 & -3.6659402 & 238 & $\mathrm{H}$ & -1.2319505 & -2.1546491 & -0.05536 \\
\hline
\end{tabular}

Table S6. Cartesian coordinates of the geometry-optimized structures of 1 and 2 obtained from the DFT B3LYP-D3(BJ) calculations at the $6-31 \mathrm{G}(\mathrm{d}, \mathrm{p})$ level. Atom numbers are indicated in the labeled structures of $\mathbf{1}(\mathrm{A})$ and $2(\mathrm{~B})$.

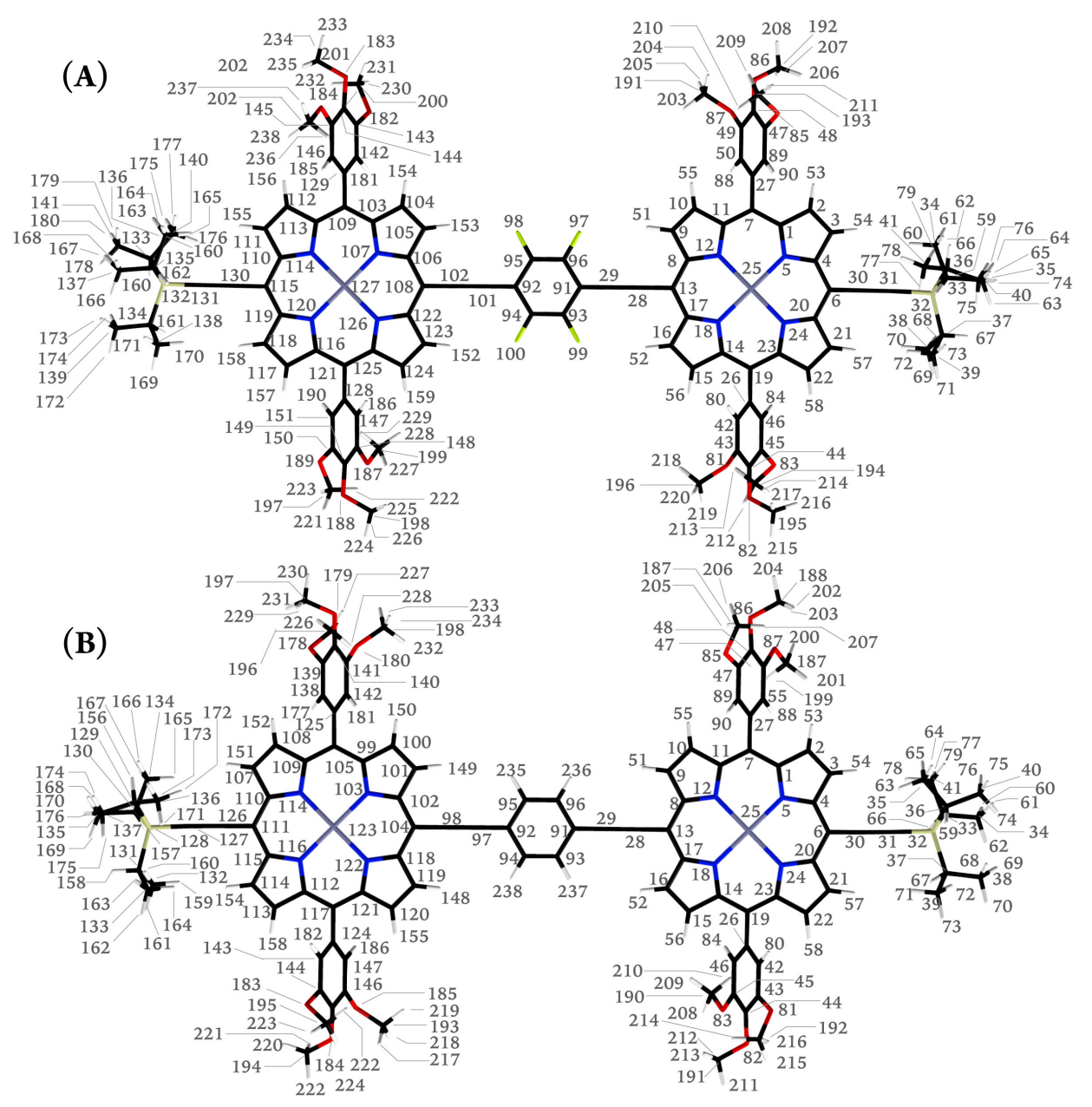

\begin{tabular}{|rrrrr|rrrrr|}
\hline \multicolumn{9}{|c|}{1} & \multicolumn{5}{c|}{$\mathbf{2}$} \\
\hline 1 & $\mathrm{C}$ & 10.1877237 & 2.7209652 & 0.022692 & 1 & $\mathrm{C}$ & 10.2059 & 2.7217 & -0.0205 \\
2 & $\mathrm{C}$ & 11.4697458 & 3.3859612 & 0.079522 & 2 & $\mathrm{C}$ & 11.4883 & 3.3872 & 0.0305
\end{tabular}




\begin{tabular}{|c|c|c|c|c|c|c|c|c|c|}
\hline 3 & $\mathrm{C}$ & 12.4238769 & 2.4129652 & 0.092263 & 3 & $\mathrm{C}$ & 12.4419 & 2.4144 & 0.056 \\
\hline 4 & $\mathrm{C}$ & 11.7311198 & 1.1501111 & 0.055248 & 4 & $\mathrm{C}$ & 11.7489 & 1.1509 & 0.0327 \\
\hline 5 & $\mathrm{~N}$ & 10.3748048 & 1.3540541 & 0.015221 & 5 & $\mathrm{~N}$ & 10.393 & 1.3543 & -0.0113 \\
\hline 6 & $\mathrm{C}$ & 12.3709609 & -0.106164 & 0.064354 & 6 & $\mathrm{C}$ & 12.389 & -0.1049 & 0.0564 \\
\hline 7 & $\mathrm{C}$ & 8.9471237 & 3.3789782 & 0.001698 & 7 & $\mathrm{C}$ & 8.9663 & 3.3777 & -0.0523 \\
\hline 8 & $\mathrm{C}$ & 6.1419995 & 1.1835571 & 0.002974 & 8 & $\mathrm{C}$ & 6.1541 & 1.1846 & -0.0309 \\
\hline 9 & $\mathrm{C}$ & 5.4594534 & 2.4509582 & -0.06908 & 9 & $\mathrm{C}$ & 5.4795 & 2.4531 & -0.1257 \\
\hline 10 & $\mathrm{C}$ & 6.4243935 & 3.4131932 & -0.080667 & 10 & $\mathrm{C}$ & 6.4459 & 3.4138 & -0.1467 \\
\hline 11 & $\mathrm{C}$ & 7.7005816 & 2.7374142 & -0.003438 & 11 & $\mathrm{C}$ & 7.7184 & 2.7356 & -0.0535 \\
\hline 12 & $\mathrm{~N}$ & 7.4978805 & 1.3717051 & 0.040123 & 12 & $\mathrm{~N}$ & 7.512 & 1.3719 & 0.0089 \\
\hline 13 & $\mathrm{C}$ & 5.4898284 & -0.067796 & 0.025358 & 13 & $\mathrm{C}$ & 5.4945 & -0.0636 & 0.0092 \\
\hline 14 & $\mathrm{C}$ & 7.6688155 & -2.8970792 & 0.085326 & 14 & $\mathrm{C}$ & 7.6836 & -2.8889 & 0.1078 \\
\hline 15 & $\mathrm{C}$ & 6.3842455 & -3.5587173 & 0.145894 & 15 & $\mathrm{C}$ & 6.4017 & -3.5518 & 0.1815 \\
\hline 16 & $\mathrm{C}$ & 5.4302534 & -2.5859502 & 0.120515 & 16 & $\mathrm{C}$ & 5.4473 & -2.5798 & 0.1446 \\
\hline 17 & $\mathrm{C}$ & 6.1276905 & -1.3261821 & 0.057181 & 17 & $\mathrm{C}$ & 6.1384 & -1.3194 & 0.0599 \\
\hline 18 & $\mathrm{~N}$ & 7.4818146 & -1.5292371 & 0.038605 & 18 & $\mathrm{~N}$ & 7.4945 & -1.5228 & 0.0417 \\
\hline 19 & $\mathrm{C}$ & 8.9081327 & -3.5525173 & 0.09539 & 19 & $\mathrm{C}$ & 8.9237 & -3.5457 & 0.1252 \\
\hline 20 & $\mathrm{C}$ & 11.7167188 & -1.3546081 & 0.069522 & 20 & $\mathrm{C}$ & 11.7332 & -1.3522 & 0.0744 \\
\hline 21 & $\mathrm{C}$ & 12.3960539 & -2.6246632 & 0.039006 & 21 & $\mathrm{C}$ & 12.4116 & -2.6235 & 0.0591 \\
\hline 22 & $\mathrm{C}$ & 11.4313638 & -3.5872893 & 0.043538 & 22 & $\mathrm{C}$ & 11.4464 & -3.585 & 0.074 \\
\hline 23 & $\mathrm{C}$ & 10.1560927 & -2.9082022 & 0.088038 & 23 & $\mathrm{C}$ & 10.1713 & -2.9044 & 0.1097 \\
\hline 24 & $\mathrm{~N}$ & 10.3579468 & -1.5434781 & 0.097505 & 24 & $\mathrm{~N}$ & 10.3746 & -1.5393 & 0.103 \\
\hline 25 & $\mathrm{Zn}$ & 8.9287446 & -0.086813 & 0.047633 & 25 & $\mathrm{Zn}$ & 8.9447 & -0.0841 & 0.0348 \\
\hline 26 & $\mathrm{C}$ & 8.9008466 & -5.0454154 & 0.113235 & 26 & $\mathrm{C}$ & 8.9146 & -5.0383 & 0.1635 \\
\hline 27 & $\mathrm{C}$ & 8.9567956 & 4.8718733 & -0.015749 & 27 & $\mathrm{C}$ & 8.9754 & 4.8704 & -0.0882 \\
\hline 28 & $\mathrm{C}$ & 4.0754763 & -0.059597 & 0.014466 & 28 & $\mathrm{C}$ & 4.0764 & -0.0546 & -0.0027 \\
\hline 29 & $\mathrm{C}$ & 2.8595882 & -0.0513 & 0.004363 & 29 & $\mathrm{C}$ & 2.8584 & -0.045 & -0.0133 \\
\hline 30 & $\mathrm{C}$ & 13.793989 & -0.112381 & 0.063464 & 30 & $\mathrm{C}$ & 13.812 & -0.1118 & 0.0578 \\
\hline 31 & $\mathrm{C}$ & 15.0152401 & -0.110873 & 0.055698 & 31 & $\mathrm{C}$ & 15.0333 & -0.1108 & 0.0523 \\
\hline 32 & $\mathrm{Si}$ & 16.8481402 & -0.040297 & 0.017266 & 32 & $\mathrm{Si}$ & 16.8656 & -0.0408 & 0.0183 \\
\hline 33 & $\mathrm{C}$ & 17.4797253 & -1.1086021 & -1.4345961 & 33 & $\mathrm{C}$ & 17.5027 & -1.1179 & -1.4249 \\
\hline 34 & $\mathrm{C}$ & 18.8690094 & -0.656564 & -1.9203961 & 34 & $\mathrm{C}$ & 18.8931 & -0.6681 & -1.9096 \\
\hline
\end{tabular}




\begin{tabular}{|c|c|c|c|c|c|c|c|c|c|}
\hline 35 & $\mathrm{C}$ & 16.4894582 & -1.1920431 & -2.6081592 & 35 & $\mathrm{C}$ & 16.5159 & -1.2095 & -2.6007 \\
\hline 36 & $\mathrm{C}$ & 17.3134133 & 1.7947311 & -0.18009 & 36 & $\mathrm{C}$ & 17.3327 & 1.7928 & -0.1889 \\
\hline 37 & $\mathrm{C}$ & 17.4698183 & -0.7195241 & 1.6830921 & 37 & $\mathrm{C}$ & 17.4838 & -0.7098 & 1.6897 \\
\hline 38 & $\mathrm{C}$ & 19.0009444 & -0.661622 & 1.8100031 & 38 & $\mathrm{C}$ & 19.0147 & -0.653 & 1.8194 \\
\hline 39 & $\mathrm{C}$ & 16.9418512 & -2.1370312 & 1.9557721 & 39 & $\mathrm{C}$ & 16.9536 & -2.1249 & 1.9706 \\
\hline 40 & $\mathrm{C}$ & 16.6931622 & 2.4063722 & -1.4475801 & 40 & $\mathrm{C}$ & 16.7169 & 2.3968 & -1.4622 \\
\hline 41 & $\mathrm{C}$ & 16.9197402 & 2.6069312 & 1.0649261 & 41 & $\mathrm{C}$ & 16.935 & 2.6129 & 1.0496 \\
\hline 42 & $\mathrm{C}$ & 8.3801926 & -5.7635284 & -0.9704981 & 42 & $\mathrm{C}$ & 8.3947 & -5.7714 & -0.9098 \\
\hline 43 & $\mathrm{C}$ & 8.3721426 & -7.1569065 & -0.9548781 & 43 & $\mathrm{C}$ & 8.3909 & -7.1661 & -0.8825 \\
\hline 44 & $\mathrm{C}$ & 8.8884556 & -7.8568565 & 0.147312 & 44 & $\mathrm{C}$ & 8.8997 & -7.8492 & 0.2331 \\
\hline 45 & $\mathrm{C}$ & 9.4024007 & -7.1382045 & 1.2380311 & 45 & $\mathrm{C}$ & 9.4069 & -7.1142 & 1.3164 \\
\hline 46 & $\mathrm{C}$ & 9.3998717 & -5.7431244 & 1.2191081 & 46 & $\mathrm{C}$ & 9.4132 & -5.721 & 1.2798 \\
\hline 47 & $\mathrm{C}$ & 9.4969207 & 6.9591695 & -1.1327471 & 47 & $\mathrm{C}$ & 9.5175 & 6.944 & -1.2296 \\
\hline 48 & $\mathrm{C}$ & 8.9780157 & 7.6832055 & -0.048028 & 48 & $\mathrm{C}$ & 8.9982 & 7.6813 & -0.1542 \\
\hline 49 & $\mathrm{C}$ & 8.4404616 & 6.9889395 & 1.0474671 & 49 & $\mathrm{C}$ & 8.4597 & 7.0005 & 0.9492 \\
\hline 50 & $\mathrm{C}$ & 8.4314706 & 5.5955394 & 1.0620361 & 50 & $\mathrm{C}$ & 8.4496 & 5.6074 & 0.9803 \\
\hline 51 & $\mathrm{H}$ & 4.3865463 & 2.5706012 & -0.113298 & 51 & $\mathrm{H}$ & 4.4083 & 2.5759 & -0.1802 \\
\hline 52 & $\mathrm{H}$ & 4.3555703 & -2.6938022 & 0.149734 & 52 & $\mathrm{H}$ & 4.374 & -2.69 & 0.1815 \\
\hline 53 & $\mathrm{H}$ & 11.6126608 & 4.4548203 & 0.112212 & 53 & $\mathrm{H}$ & 11.6314 & 4.4564 & 0.0507 \\
\hline 54 & $\mathrm{H}$ & 13.496876 & 2.5250032 & 0.133932 & 54 & $\mathrm{H}$ & 13.5149 & 2.5265 & 0.0978 \\
\hline 55 & $\mathrm{H}$ & 6.2933635 & 4.4822373 & -0.142996 & 55 & $\mathrm{H}$ & 6.3181 & 4.4821 & -0.226 \\
\hline 56 & $\mathrm{H}$ & 6.2405195 & -4.6261943 & 0.206852 & 56 & $\mathrm{H}$ & 6.2598 & -4.6185 & 0.2586 \\
\hline 57 & $\mathrm{H}$ & 13.468552 & -2.7462112 & 0.008312 & 57 & $\mathrm{H}$ & 13.4841 & -2.746 & 0.0305 \\
\hline 58 & $\mathrm{H}$ & 11.5624828 & -4.6577313 & 0.012946 & 58 & $\mathrm{H}$ & 11.5767 & -4.6559 & 0.0554 \\
\hline 59 & $\mathrm{H}$ & 17.5856692 & -2.1217942 & -1.0199361 & 59 & $\mathrm{H}$ & 17.6082 & -2.1284 & -1.0034 \\
\hline 60 & $\mathrm{H}$ & 19.6054784 & -0.623195 & -1.1116691 & 60 & $\mathrm{H}$ & 19.6272 & -0.629 & -1.099 \\
\hline 61 & $\mathrm{H}$ & 18.8274954 & 0.342536 & -2.3673512 & 61 & $\mathrm{H}$ & 18.8522 & 0.328 & -2.3631 \\
\hline 62 & $\mathrm{H}$ & 19.2531204 & -1.3387231 & -2.6885222 & 62 & $\mathrm{H}$ & 19.2799 & -1.3549 & -2.6723 \\
\hline 63 & $\mathrm{H}$ & 15.5117111 & -1.5615641 & -2.2881202 & 63 & $\mathrm{H}$ & 15.5374 & -1.5772 & -2.2809 \\
\hline 64 & $\mathrm{H}$ & 16.8694732 & -1.8607851 & -3.3904192 & 64 & $\mathrm{H}$ & 16.8983 & -1.8832 & -3.3775 \\
\hline 65 & $\mathrm{H}$ & 16.3294602 & -0.210824 & -3.0676182 & 65 & $\mathrm{H}$ & 16.3568 & -0.2314 & -3.067 \\
\hline 66 & $\mathrm{H}$ & 18.4075953 & 1.8332661 & -0.281401 & 66 & $\mathrm{H}$ & 18.4272 & 1.8303 & -0.2868 \\
\hline
\end{tabular}




\begin{tabular}{|c|c|c|c|c|c|c|c|c|c|}
\hline 67 & $\mathrm{H}$ & 17.0394863 & -0.052581 & 2.4432032 & 67 & $\mathrm{H}$ & 17.0527 & -0.0375 & 2.4446 \\
\hline 68 & $\mathrm{H}$ & 19.3934634 & 0.346126 & 1.6364451 & 68 & $\mathrm{H}$ & 19.4087 & 0.3532 & 1.6401 \\
\hline 69 & $\mathrm{H}$ & 19.4836214 & -1.3338381 & 1.0917471 & 69 & $\mathrm{H}$ & 19.498 & -1.3303 & 1.1064 \\
\hline 70 & $\mathrm{H}$ & 19.3246694 & -0.9742981 & 2.8102282 & 70 & $\mathrm{H}$ & 19.3362 & -0.9596 & 2.8223 \\
\hline 71 & $\mathrm{H}$ & 15.8490672 & -2.1744522 & 1.9115221 & 71 & $\mathrm{H}$ & 15.8608 & -2.1611 & 1.9245 \\
\hline 72 & $\mathrm{H}$ & 17.2508802 & -2.4883142 & 2.9478612 & 72 & $\mathrm{H}$ & 17.2603 & -2.4703 & 2.9655 \\
\hline 73 & $\mathrm{H}$ & 17.3303693 & -2.85566662 & 1.2244901 & 73 & $\mathrm{H}$ & 17.3425 & -2.8487 & 1.2446 \\
\hline 74 & $\mathrm{H}$ & 15.6001361 & 2.3365942 & -1.4235241 & 74 & $\mathrm{H}$ & 15.6238 & 2.3271 & -1.4415 \\
\hline 75 & $\mathrm{H}$ & 17.0321342 & 1.9014001 & -2.3570672 & 75 & $\mathrm{H}$ & 17.0589 & 1.8863 & -2.3675 \\
\hline 76 & $\mathrm{H}$ & 16.9559782 & 3.4672833 & -1.5405601 & 76 & $\mathrm{H}$ & 16.9801 & 3.4571 & -1.5608 \\
\hline 77 & $\mathrm{H}$ & 17.4335203 & 2.2562192 & 1.9653371 & 77 & $\mathrm{H}$ & 17.4454 & 2.2676 & 1.954 \\
\hline 78 & $\mathrm{H}$ & 15.8421451 & 2.5413492 & 1.2549041 & 78 & $\mathrm{H}$ & 15.8567 & 2.5489 & 1.236 \\
\hline 79 & $\mathrm{H}$ & 17.1662372 & 3.6678393 & 0.9350221 & 79 & $\mathrm{H}$ & 17.1824 & 3.673 & 0.914 \\
\hline 80 & $\mathrm{H}$ & 7.9899596 & -5.2508314 & -1.8419311 & 80 & $\mathrm{H}$ & 8.0085 & -5.2696 & -1.7894 \\
\hline 81 & $\mathrm{O}$ & 7.9194486 & -7.8303656 & -2.0643341 & 81 & $\mathrm{O}$ & 7.9541 & -7.8438 & -1.9922 \\
\hline 82 & $\mathrm{O}$ & 8.8989057 & -9.2337447 & 0.163645 & 82 & $\mathrm{O}$ & 8.9035 & -9.2263 & 0.2538 \\
\hline 83 & $\mathrm{O}$ & 9.9737627 & -7.7785056 & 2.3075572 & 83 & $\mathrm{O}$ & 9.9626 & -7.7517 & 2.3999 \\
\hline 84 & $\mathrm{H}$ & 9.8008747 & -5.2133044 & 2.0753201 & 84 & $\mathrm{H}$ & 9.8118 & -5.1802 & 2.1302 \\
\hline 85 & $\mathrm{O}$ & 10.0896237 & 7.5936986 & -2.1941412 & 85 & $\mathrm{O}$ & 10.1118 & 7.5658 & -2.2979 \\
\hline 86 & $\mathrm{O}$ & 9.0051847 & 9.0600297 & -0.062396 & 86 & $\mathrm{O}$ & 9.0266 & 9.0581 & -0.1845 \\
\hline 87 & $\mathrm{O}$ & 7.9836226 & 7.6671276 & 2.1524152 & 87 & $\mathrm{O}$ & 8.0034 & 7.6922 & 2.0462 \\
\hline 88 & $\mathrm{H}$ & 8.0250366 & 5.0869094 & 1.9284301 & 88 & $\mathrm{H}$ & 8.0425 & 5.1093 & 1.8525 \\
\hline 89 & $\mathrm{C}$ & 9.4775287 & 5.5642524 & -1.1149931 & 89 & $\mathrm{C}$ & 9.4972 & 5.5494 & -1.1953 \\
\hline 90 & $\mathrm{H}$ & 9.8828737 & 5.0301694 & -1.9664901 & 90 & $\mathrm{H}$ & 9.9032 & 5.0048 & -2.0397 \\
\hline 91 & $\mathrm{C}$ & 1.4541981 & -0.03965 & -0.007888 & 91 & $\mathrm{C}$ & 1.4423 & -0.0308 & -0.0255 \\
\hline 92 & $\mathrm{C}$ & -1.3949181 & -0.014926 & -0.033283 & 92 & $\mathrm{C}$ & -1.3849 & -0.0001 & -0.0491 \\
\hline 93 & $\mathrm{C}$ & 0.7102441 & -1.2347181 & 0.024503 & 93 & $\mathrm{C}$ & 0.7078 & -1.2358 & -0.0474 \\
\hline 94 & $\mathrm{C}$ & -0.672624 & -1.2228651 & 0.011836 & 94 & $\mathrm{C}$ & -0.6765 & -1.2208 & -0.0592 \\
\hline 95 & $\mathrm{C}$ & -0.650787 & 1.1801121 & -0.065198 & 95 & $\mathrm{C}$ & -0.6503 & 1.205 & -0.0275 \\
\hline 96 & $\mathrm{C}$ & 0.7318271 & 1.1681611 & -0.053325 & 96 & $\mathrm{C}$ & 0.7338 & 1.19 & -0.0161 \\
\hline 97 & $\mathrm{~F}$ & 1.4010611 & 2.3302962 & -0.085978 & 97 & $\mathrm{C}$ & -2.8009 & 0.0161 & -0.0597 \\
\hline 98 & $\mathrm{~F}$ & -1.2989331 & 2.3539072 & -0.108597 & 98 & $\mathrm{C}$ & -4.019 & 0.031 & -0.0681 \\
\hline
\end{tabular}




\begin{tabular}{|c|c|c|c|c|c|c|c|c|c|}
\hline 99 & $\mathrm{~F}$ & 1.3587311 & -2.4077542 & 0.069362 & 99 & $\mathrm{C}$ & -7.6044 & 2.8939 & -0.0188 \\
\hline 100 & $\mathrm{~F}$ & -1.3418431 & -2.3842722 & 0.044247 & 100 & $\mathrm{C}$ & -6.318 & 3.5498 & -0.0716 \\
\hline 101 & $\mathrm{C}$ & -2.8002302 & -0.001444 & -0.045104 & 101 & $\mathrm{C}$ & -5.3708 & 2.5699 & -0.0899 \\
\hline 102 & $\mathrm{C}$ & -4.0160883 & 0.01422 & -0.055819 & 102 & $\mathrm{C}$ & -6.0711 & 1.3121 & -0.0614 \\
\hline 103 & $\mathrm{C}$ & -7.5757885 & 2.8935932 & -0.057229 & 103 & $\mathrm{~N}$ & -7.4253 & 1.5248 & -0.022 \\
\hline 104 & $\mathrm{C}$ & -6.2837925 & 3.5407453 & -0.114885 & 104 & $\mathrm{C}$ & -5.437 & 0.0502 & -0.0758 \\
\hline 105 & $\mathrm{C}$ & -5.3412134 & 2.5563042 & -0.114495 & 105 & $\mathrm{C}$ & -8.8391 & 3.5613 & 0.0109 \\
\hline 106 & $\mathrm{C}$ & -6.0531245 & 1.3039471 & -0.070807 & 106 & $\mathrm{C}$ & -11.6647 & 1.388 & -0.0285 \\
\hline 107 & $\mathrm{~N}$ & -7.4045635 & 1.5228701 & -0.039296 & 107 & $\mathrm{C}$ & -12.333 & 2.6613 & 0.0647 \\
\hline 108 & $\mathrm{C}$ & -5.4302674 & 0.037427 & -0.066216 & 108 & $\mathrm{C}$ & -11.3608 & 3.6154 & 0.0931 \\
\hline 109 & $\mathrm{C}$ & -8.8070346 & 3.5648383 & -0.040689 & 109 & $\mathrm{C}$ & -10.0913 & 2.9287 & 0.0053 \\
\hline 110 & $\mathrm{C}$ & -11.640642 & 1.3985151 & -0.047457 & 110 & $\mathrm{~N}$ & -10.3048 & 1.5665 & -0.0606 \\
\hline 111 & $\mathrm{C}$ & -12.304718 & 2.6747592 & 0.026789 & 111 & $\mathrm{C}$ & -12.3298 & 0.1466 & -0.077 \\
\hline 112 & $\mathrm{C}$ & -11.329228 & 3.6262173 & 0.040578 & 112 & $\mathrm{C}$ & -10.168 & -2.6962 & -0.1856 \\
\hline 113 & $\mathrm{C}$ & -10.06229 & 2.9343832 & -0.037216 & 113 & C & -11.4558 & -3.3463 & -0.2804 \\
\hline 114 & $\mathrm{~N}$ & -10.279833 & 1.5725311 & -0.082602 & 114 & $\mathrm{C}$ & -12.4025 & -2.3665 & -0.2416 \\
\hline 115 & $\mathrm{C}$ & -12.309209 & 0.158334 & -0.077319 & 115 & $\mathrm{C}$ & -11.6992 & -1.1131 & -0.1366 \\
\hline 116 & $\mathrm{C}$ & -10.15887 & -2.6943052 & -0.141909 & 116 & $\mathrm{~N}$ & -10.345 & -1.3295 & -0.108 \\
\hline 117 & $\mathrm{C}$ & -11.448715 & -3.3406262 & -0.229131 & 117 & $\mathrm{C}$ & -8.9336 & -3.3641 & -0.1906 \\
\hline 118 & $\mathrm{C}$ & -12.3919 & -2.3565752 & -0.205474 & 118 & C & -6.1057 & -1.1934 & -0.0979 \\
\hline 119 & $\mathrm{C}$ & -11.684058 & -1.1049181 & -0.117637 & 119 & C & -5.4404 & -2.4703 & -0.0726 \\
\hline 120 & $\mathrm{~N}$ & -10.330329 & -1.3265651 & -0.084035 & 120 & $\mathrm{C}$ & -6.4134 & -3.4238 & -0.1008 \\
\hline 121 & $\mathrm{C}$ & -8.9262226 & -3.3689532 & -0.136259 & 121 & $\mathrm{C}$ & -7.681 & -2.7322 & -0.1553 \\
\hline 122 & $\mathrm{C}$ & -6.0967264 & -1.2064421 & -0.072651 & 122 & $\mathrm{~N}$ & -7.4652 & -1.368 & -0.1441 \\
\hline 123 & $\mathrm{C}$ & -5.4289664 & -2.4831802 & -0.031276 & 123 & $\mathrm{Zn}$ & -8.8859 & 0.0986 & -0.0905 \\
\hline 124 & $\mathrm{C}$ & -6.4043754 & -3.4345392 & -0.046674 & 124 & $\mathrm{C}$ & -8.9566 & -4.8563 & -0.2281 \\
\hline 125 & $\mathrm{C}$ & -7.6725735 & -2.7421382 & -0.109649 & 125 & $\mathrm{C}$ & -8.8166 & 5.0533 & 0.0593 \\
\hline 126 & $\mathrm{~N}$ & -7.4547235 & -1.3775951 & -0.116475 & 126 & $\mathrm{C}$ & -13.7527 & 0.1606 & -0.0626 \\
\hline 127 & $\mathrm{Zn}$ & -8.8674906 & 0.097876 & -0.08782 & 127 & $\mathrm{C}$ & -14.974 & 0.1557 & -0.049 \\
\hline 128 & $\mathrm{C}$ & -8.9563907 & -4.8612823 & -0.153117 & 128 & $\mathrm{Si}$ & -16.8086 & 0.1077 & -0.0046 \\
\hline 129 & $\mathrm{C}$ & -8.7807466 & 5.0571654 & -0.017076 & 129 & $\mathrm{C}$ & -17.3748 & 1.9136 & -0.2243 \\
\hline 130 & $\mathrm{C}$ & -13.732143 & 0.177495 & -0.063751 & 130 & $\mathrm{C}$ & -17.3864 & -0.9605 & -1.4793 \\
\hline
\end{tabular}




\begin{tabular}{|c|c|c|c|c|c|c|c|c|c|}
\hline 131 & $\mathrm{C}$ & -14.953341 & 0.176332 & -0.050556 & 131 & $\mathrm{C}$ & -17.2515 & -0.5918 & 1.7133 \\
\hline 132 & $\mathrm{Si}$ & -16.788717 & 0.132489 & -0.006373 & 132 & $\mathrm{C}$ & -16.7474 & -2.0347 & 1.8869 \\
\hline 133 & $\mathrm{C}$ & -17.350743 & 1.9377791 & -0.239455 & 133 & $\mathrm{C}$ & -18.7331 & -0.4692 & 2.1068 \\
\hline 134 & $\mathrm{C}$ & -17.36713 & -0.9458431 & -1.4731991 & 134 & $\mathrm{C}$ & -16.4138 & -2.105 & -1.8139 \\
\hline 135 & $\mathrm{C}$ & -17.231795 & -0.553684 & 1.7168381 & 135 & $\mathrm{C}$ & -18.8194 & -1.4995 & -1.3227 \\
\hline 136 & $\mathrm{C}$ & -16.730159 & -1.9961681 & 1.9008101 & 136 & $\mathrm{C}$ & -17.0078 & 2.7676 & 1.0007 \\
\hline 137 & $\mathrm{C}$ & -18.713217 & -0.425806 & 2.1094172 & 137 & $\mathrm{C}$ & -18.8543 & 2.0828 & -0.6059 \\
\hline 138 & $\mathrm{C}$ & -16.396525 & -2.0947432 & -1.7983631 & 138 & $\mathrm{C}$ & -8.2695 & 5.7066 & 1.1749 \\
\hline 139 & $\mathrm{C}$ & -18.801274 & -1.4808411 & -1.3130511 & 139 & $\mathrm{C}$ & -8.2509 & 7.0987 & 1.2265 \\
\hline 140 & $\mathrm{C}$ & -16.981659 & 2.8000422 & 0.9791251 & 140 & $\mathrm{C}$ & -8.7615 & 7.8686 & 0.1566 \\
\hline 141 & $\mathrm{C}$ & -18.830135 & 2.1070422 & -0.621846 & 141 & $\mathrm{C}$ & -9.2991 & 7.2064 & -0.9582 \\
\hline 142 & $\mathrm{C}$ & -8.2264496 & 5.7275534 & 1.0847941 & 142 & $\mathrm{C}$ & -9.3273 & 5.8051 & -0.994 \\
\hline 143 & $\mathrm{C}$ & -8.2027046 & 7.1202865 & 1.1122351 & 143 & $\mathrm{C}$ & -8.4389 & -5.5473 & -1.319 \\
\hline 144 & $\mathrm{C}$ & -8.7157556 & 7.8733776 & 0.031576 & 144 & $\mathrm{C}$ & -8.4692 & -6.9483 & -1.3638 \\
\hline 145 & $\mathrm{C}$ & -9.2608857 & 7.1940065 & -1.0691801 & 145 & $\mathrm{C}$ & -9.0162 & -7.6725 & -0.2931 \\
\hline 146 & $\mathrm{C}$ & -9.2940317 & 5.7923964 & -1.0807941 & 146 & $\mathrm{C}$ & -9.5341 & -6.9645 & 0.8153 \\
\hline 147 & $\mathrm{C}$ & -8.4404276 & -5.5690794 & -1.2338471 & 147 & $\mathrm{C}$ & -9.513 & -5.5718 & 0.844 \\
\hline 148 & $\mathrm{C}$ & -8.4773856 & -6.9705755 & -1.2601641 & 148 & $\mathrm{H}$ & -4.3701 & -2.6043 & -0.0295 \\
\hline 149 & $\mathrm{C}$ & -9.0290887 & -7.6775416 & -0.180277 & 149 & $\mathrm{H}$ & -4.2971 & 2.6734 & -0.1322 \\
\hline 150 & $\mathrm{C}$ & -9.5447687 & -6.9520975 & 0.9179971 & 150 & $\mathrm{H}$ & -6.1694 & 4.618 & -0.1008 \\
\hline 151 & $\mathrm{C}$ & -9.5175757 & -5.5593124 & 0.9279831 & 151 & $\mathrm{H}$ & -13.4043 & 2.7901 & 0.1076 \\
\hline 152 & $\mathrm{H}$ & -4.3576223 & -2.6166082 & 0.011428 & 152 & $\mathrm{H}$ & -11.4817 & 4.6846 & 0.1701 \\
\hline 153 & $\mathrm{H}$ & -4.2655873 & 2.6519172 & -0.150981 & 153 & $\mathrm{H}$ & -11.6054 & -4.4105 & -0.3745 \\
\hline 154 & $\mathrm{H}$ & -6.1286824 & 4.6074383 & -0.159238 & 154 & $\mathrm{H}$ & -13.4764 & -2.4656 & -0.2938 \\
\hline 155 & $\mathrm{H}$ & -13.375535 & 2.8078732 & 0.068248 & 155 & $\mathrm{H}$ & -6.2936 & -4.4958 & -0.082 \\
\hline 156 & $\mathrm{H}$ & -11.446675 & 4.6968503 & 0.101738 & 156 & $\mathrm{H}$ & -16.7732 & 2.2741 & -1.0719 \\
\hline 157 & $\mathrm{H}$ & -11.602284 & -4.4055433 & -0.308146 & 157 & $\mathrm{H}$ & -17.3818 & -0.2648 & -2.3324 \\
\hline 158 & $\mathrm{H}$ & -13.466151 & -2.4525122 & -0.258033 & 158 & $\mathrm{H}$ & -16.6736 & 0.0408 & 2.4027 \\
\hline 159 & $\mathrm{H}$ & -6.2860915 & -4.5063603 & -0.014371 & 159 & $\mathrm{H}$ & -16.8828 & -2.3748 & 2.921 \\
\hline 160 & $\mathrm{H}$ & -16.748785 & 2.2908352 & -1.0899811 & 160 & $\mathrm{H}$ & -15.6842 & -2.1226 & 1.6424 \\
\hline 161 & $\mathrm{H}$ & -17.360802 & -0.256738 & -2.3315692 & 161 & $\mathrm{H}$ & -17.2977 & -2.7303 & 1.2438 \\
\hline 162 & $\mathrm{H}$ & -16.652893 & 0.083082 & 2.4015612 & 162 & $\mathrm{H}$ & -19.3812 & -1.0473 & 1.4415 \\
\hline
\end{tabular}




\begin{tabular}{|c|c|c|c|c|c|c|c|c|c|}
\hline 163 & $\mathrm{H}$ & -16.866554 & -2.3286122 & 2.9372832 & 163 & $\mathrm{H}$ & -19.0793 & 0.5682 & 2.0862 \\
\hline 164 & $\mathrm{H}$ & -15.666923 & -2.0877132 & 1.6575271 & 164 & $\mathrm{H}$ & -18.8937 & -0.8472 & 3.1242 \\
\hline 165 & $\mathrm{H}$ & -17.281376 & -2.6953312 & 1.2624541 & 165 & $\mathrm{H}$ & -16.3568 & -2.8307 & -0.995 \\
\hline 166 & $\mathrm{H}$ & -19.362265 & -1.0076881 & 1.4482701 & 166 & $\mathrm{H}$ & -15.402 & -1.735 & -1.9984 \\
\hline 167 & $\mathrm{H}$ & -19.05773 & 0.611997 & 2.0813681 & 167 & $\mathrm{H}$ & -16.7462 & -2.6487 & -2.7069 \\
\hline 168 & $\mathrm{H}$ & -18.874251 & -0.7962941 & 3.1295132 & 168 & $\mathrm{H}$ & -19.544 & -0.7124 & -1.0947 \\
\hline 169 & $\mathrm{H}$ & -16.341145 & -2.8140022 & -0.9737191 & 169 & $\mathrm{H}$ & -18.875 & -2.2419 & -0.5198 \\
\hline 170 & $\mathrm{H}$ & -15.383979 & -1.7282721 & -1.9856961 & 170 & $\mathrm{H}$ & -19.1494 & -1.9959 & -2.2435 \\
\hline 171 & $\mathrm{H}$ & -16.729744 & -2.6449212 & -2.6870562 & 171 & $\mathrm{H}$ & -15.9469 & 2.6751 & 1.256 \\
\hline 172 & $\mathrm{H}$ & -19.524427 & -0.690641 & -1.0913341 & 172 & $\mathrm{H}$ & -17.5859 & 2.47 & 1.8826 \\
\hline 173 & $\mathrm{H}$ & -18.858608 & -2.2170522 & -0.504577 & 173 & $\mathrm{H}$ & -17.2169 & 3.8288 & 0.8186 \\
\hline 174 & $\mathrm{H}$ & -19.131787 & -1.9835621 & -2.2302092 & 174 & $\mathrm{H}$ & -19.5235 & 1.7069 & 0.1751 \\
\hline 175 & $\mathrm{H}$ & -15.92082 & 2.7075482 & 1.2346601 & 175 & $\mathrm{H}$ & -19.0992 & 1.5564 & -1.5334 \\
\hline 176 & $\mathrm{H}$ & -17.55992 & 2.5098682 & 1.8634611 & 176 & $\mathrm{H}$ & -19.097 & 3.142 & -0.7562 \\
\hline 177 & $\mathrm{H}$ & -17.188935 & 3.8601743 & 0.7893911 & 177 & $\mathrm{H}$ & -7.8874 & 5.1136 & 1.9946 \\
\hline 178 & $\mathrm{H}$ & -19.499687 & 1.7379341 & 0.162041 & 178 & $\mathrm{O}$ & -7.7846 & 7.8169 & 2.2904 \\
\hline 179 & $\mathrm{H}$ & -19.076315 & 1.5744371 & -1.5454921 & 179 & $\mathrm{O}$ & -8.826 & 9.2387 & 0.2451 \\
\hline 180 & $\mathrm{H}$ & -19.070844 & 3.1656002 & -0.7795991 & 180 & $\mathrm{O}$ & -9.8673 & 7.8258 & -2.0319 \\
\hline 181 & $\mathrm{H}$ & -7.8427906 & 5.1476524 & 1.9129241 & 181 & $\mathrm{H}$ & -9.7417 & 5.3258 & -1.8726 \\
\hline 182 & $\mathrm{O}$ & -7.7290865 & 7.8548826 & 2.1612872 & 182 & $\mathrm{H}$ & -8.0176 & -5.0192 & -2.1659 \\
\hline 183 & $\mathrm{O}$ & -8.7749206 & 9.2448227 & 0.09606 & 183 & $\mathrm{O}$ & -7.8939 & -7.5067 & -2.4669 \\
\hline 184 & $\mathrm{O}$ & -9.8316617 & 7.7970116 & -2.1506872 & 184 & $\mathrm{O}$ & -8.9542 & -9.0455 & -0.2837 \\
\hline 185 & $\mathrm{H}$ & -9.7135217 & 5.2997684 & -1.9495991 & 185 & $\mathrm{O}$ & -10.0097 & -7.7416 & 1.8327 \\
\hline 186 & $\mathrm{H}$ & -8.0156196 & -5.0544984 & -2.0871982 & 186 & $\mathrm{H}$ & -9.9005 & -5.0262 & 1.6933 \\
\hline 187 & $\mathrm{O}$ & -7.9036835 & -7.5447906 & -2.3554582 & 187 & $\mathrm{C}$ & 6.8224 & 8.4692 & 1.8179 \\
\hline 188 & $\mathrm{O}$ & -8.9738227 & -9.0504227 & -0.151443 & 188 & $\mathrm{C}$ & 10.1069 & 9.6163 & 0.5756 \\
\hline 189 & $\mathrm{O}$ & -10.024754 & -7.7133356 & 1.9450381 & 189 & $\mathrm{C}$ & 9.243 & 8.372 & -3.101 \\
\hline 190 & $\mathrm{H}$ & -9.9034397 & -5.0007064 & 1.7696141 & 190 & $\mathrm{C}$ & 9.0383 & -8.5015 & 3.1973 \\
\hline 191 & $\mathrm{C}$ & 6.8000775 & 8.4435416 & 1.9334931 & 191 & $\mathrm{C}$ & 10.1824 & -9.7918 & -0.0638 \\
\hline 192 & $\mathrm{C}$ & 10.0796537 & 9.6114217 & 0.710897 & 192 & $\mathrm{C}$ & 6.7855 & -8.6472 & -1.7983 \\
\hline 193 & $\mathrm{C}$ & 9.2198817 & 8.4099446 & -2.9861982 & 193 & $\mathrm{C}$ & -10.5068 & -7.0862 & 2.9896 \\
\hline 194 & $\mathrm{C}$ & 9.0846857 & -8.5849726 & 3.0881102 & 194 & $\mathrm{C}$ & -10.2106 & -9.7301 & -0.3069 \\
\hline
\end{tabular}




\begin{tabular}{|c|c|c|c|c|c|c|c|c|c|}
\hline 195 & $\mathrm{C}$ & 9.9666737 & -9.8003637 & -0.607999 & 195 & $\mathrm{C}$ & -8.4298 & -8.7065 & -3.0227 \\
\hline 196 & $\mathrm{C}$ & 6.7227985 & -8.5904806 & -1.8583271 & 196 & $\mathrm{C}$ & -7.2994 & 7.0971 & 3.4135 \\
\hline 197 & $\mathrm{C}$ & -10.517508 & -7.0406475 & 3.0938592 & 197 & $\mathrm{C}$ & -7.5708 & 9.9251 & 0.2701 \\
\hline 198 & $\mathrm{C}$ & -10.233278 & -9.7295247 & -0.167721 & 198 & $\mathrm{C}$ & -9.3349 & 9.0598 & -2.5108 \\
\hline 199 & $\mathrm{C}$ & -8.4335686 & -8.7568616 & -2.8900172 & 199 & $\mathrm{H}$ & 5.9907 & 7.8232 & 1.51 \\
\hline 200 & $\mathrm{C}$ & -7.2338435 & 7.1528735 & 3.2914702 & 200 & $\mathrm{H}$ & 6.9931 & 9.2355 & 1.057 \\
\hline 201 & $\mathrm{C}$ & -7.5170765 & 9.9273507 & 0.104378 & 201 & $\mathrm{H}$ & 6.5791 & 8.94 & 2.7719 \\
\hline 202 & $\mathrm{C}$ & -9.2949107 & 9.0192787 & -2.6545572 & 202 & $\mathrm{H}$ & 11.07 & 9.2822 & 0.1745 \\
\hline 203 & $\mathrm{H}$ & 5.9700084 & 7.7987276 & 1.6194201 & 203 & $\mathrm{H}$ & 10.0235 & 9.3332 & 1.6296 \\
\hline 204 & $\mathrm{H}$ & 6.9682255 & 9.2185017 & 1.1808551 & 204 & $\mathrm{H}$ & 10.025 & 10.7001 & 0.4764 \\
\hline 205 & $\mathrm{H}$ & 6.5565855 & 8.9032486 & 2.8927952 & 205 & $\mathrm{H}$ & 8.8237 & 9.1998 & -2.5237 \\
\hline 206 & $\mathrm{H}$ & 11.0459308 & 9.2834957 & 0.312183 & 206 & $\mathrm{H}$ & 8.4311 & 7.7641 & -3.5194 \\
\hline 207 & $\mathrm{H}$ & 9.9900097 & 9.3163636 & 1.7610831 & 207 & $\mathrm{H}$ & 9.8579 & 8.7604 & -3.9147 \\
\hline 208 & $\mathrm{H}$ & 9.9965277 & 10.6960998 & 0.62323 & 208 & $\mathrm{H}$ & 8.5707 & -9.3004 & 2.6157 \\
\hline 209 & $\mathrm{H}$ & 8.8019176 & 9.2308766 & -2.3983332 & 209 & $\mathrm{H}$ & 8.2636 & -7.8429 & 3.6084 \\
\hline 210 & $\mathrm{H}$ & 8.4070886 & 7.8075365 & -3.4105652 & 210 & $\mathrm{H}$ & 9.6205 & -8.9288 & 4.0154 \\
\hline 211 & $\mathrm{H}$ & 9.8337977 & 8.8077617 & -3.7960673 & 211 & $\mathrm{H}$ & 10.0598 & -10.8752 & -0.0173 \\
\hline 212 & $\mathrm{H}$ & 8.6661986 & -9.4018977 & 2.4951142 & 212 & $\mathrm{H}$ & 10.9364 & -9.4727 & 0.6627 \\
\hline 213 & $\mathrm{H}$ & 8.2725216 & -7.9737206 & 3.5008923 & 213 & $\mathrm{H}$ & 10.4901 & -9.4996 & -1.0738 \\
\hline 214 & $\mathrm{H}$ & 9.6832457 & -8.9885746 & 3.9065743 & 214 & $\mathrm{H}$ & 5.9408 & -8.0269 & -1.4729 \\
\hline 215 & $\mathrm{H}$ & 9.8694847 & -10.883673 & -0.51809 & 215 & $\mathrm{H}$ & 6.9648 & -9.4384 & -1.066 \\
\hline 216 & $\mathrm{H}$ & 10.9368298 & -9.4841257 & -0.209202 & 216 & $\mathrm{H}$ & 6.5554 & -9.0861 & -2.7707 \\
\hline 217 & $\mathrm{H}$ & 9.8816137 & -9.5062587 & -1.6587641 & 217 & $\mathrm{H}$ & -9.7302 & -6.48 & 3.4708 \\
\hline 218 & $\mathrm{H}$ & 5.8980374 & -7.9339586 & -1.5549401 & 218 & $\mathrm{H}$ & -10.8213 & -7.8782 & 3.6699 \\
\hline 219 & $\mathrm{H}$ & 6.8715745 & -9.3664906 & -1.1026801 & 219 & $\mathrm{H}$ & -11.3659 & -6.4463 & 2.7532 \\
\hline 220 & $\mathrm{H}$ & 6.4844255 & -9.0482296 & -2.8198002 & 220 & $\mathrm{H}$ & -10.7912 & -9.4506 & -1.1952 \\
\hline 221 & $\mathrm{H}$ & -9.7372727 & -6.4322415 & 3.5665143 & 221 & $\mathrm{H}$ & -10.7938 & -9.5192 & 0.5918 \\
\hline 222 & $\mathrm{H}$ & -10.835261 & -7.8222106 & 3.7846033 & 222 & $\mathrm{H}$ & -9.9733 & -10.7946 & -0.3517 \\
\hline 223 & $\mathrm{H}$ & -11.373643 & -6.3995535 & 2.8500272 & 223 & $\mathrm{H}$ & -9.5249 & -8.6668 & -3.0647 \\
\hline 224 & $\mathrm{H}$ & -10.810175 & -9.4608197 & -1.0618101 & 224 & $\mathrm{H}$ & -8.1219 & -9.5878 & -2.4582 \\
\hline 225 & $\mathrm{H}$ & -10.817835 & -9.5022487 & 0.7260531 & 225 & $\mathrm{H}$ & -8.0374 & -8.7577 & -4.0405 \\
\hline 226 & $\mathrm{H}$ & -10.000756 & -10.795606 & -0.195724 & 226 & $\mathrm{H}$ & -8.0808 & 6.4643 & 3.8511 \\
\hline
\end{tabular}




\begin{tabular}{|cccccc|ccccc|}
227 & $\mathrm{H}$ & -9.5287617 & -8.7232086 & -2.9336802 & 227 & $\mathrm{H}$ & -6.993 & 7.8492 & 4.1411 \\
228 & $\mathrm{H}$ & -8.1218456 & -9.6265277 & -2.3098372 & 228 & $\mathrm{H}$ & -6.4373 & 6.4717 & 3.1507 \\
229 & $\mathrm{H}$ & -8.0399256 & -8.8238897 & -3.9063953 & 229 & $\mathrm{H}$ & -7.8095 & 10.99 & 0.2875 \\
230 & $\mathrm{H}$ & -8.0118106 & 6.5288395 & 3.7472223 & 230 & $\mathrm{H}$ & -6.9845 & 9.6999 & -0.6299 \\
231 & $\mathrm{H}$ & -6.9192015 & 7.9164916 & 4.0033663 & 231 & $\mathrm{H}$ & -6.9924 & 9.6616 & 1.158 \\
232 & $\mathrm{H}$ & -6.3752615 & 6.5220555 & 3.0302962 & 232 & $\mathrm{H}$ & -8.2393 & 9.0296 & -2.546 \\
233 & $\mathrm{H}$ & -7.7523616 & 10.9931878 & 0.10335 & 233 & $\mathrm{H}$ & -9.6533 & 9.9041 & -1.8977 \\
234 & $\mathrm{H}$ & -6.9349085 & 9.6837937 & -0.7934471 & 234 & $\mathrm{H}$ & -9.7195 & 9.1689 & -3.527 \\
235 & $\mathrm{H}$ & -6.9365875 & 9.6779047 & 0.9948521 & 235 & $\mathrm{H}$ & -1.1854 & 2.1484 & -0.0196 \\
236 & $\mathrm{H}$ & -8.1996836 & 8.9824306 & -2.6940792 & 236 & $\mathrm{H}$ & 1.2891 & 2.1215 & -0.0012 \\
237 & $\mathrm{H}$ & -9.6060927 & 9.8762647 & -2.0554782 & 237 & $\mathrm{H}$ & 1.2427 & -2.1792 & -0.0564 \\
238 & $\mathrm{H}$ & -9.6835997 & 9.1117776 & -3.6708623 & 238 & $\mathrm{H}$ & -1.2316 & -2.1524 & -0.077 \\
\hline
\end{tabular}

\section{Reference}

S1. Kasha, M. Energy transfer mechanisms and the molecular exciton model for molecular aggregates. Radiat. Res. 1963, 20, 55-71.

S2. Kasha, M.; Rawls, H. R.; El-Bayoumi, M. A. The exciton model in molecular spectroscopy. Pure Appl. Chem. 1965, 11, 371-392.

S3. Satake, A.; Kobuke, Y. Dynamic supramolecular porphyrin systems. Tetrahedron 2005, 61, 13-41.

S4. Anderson, H. L. Conjugated porphyrin ladders. Inorg. Chem. 1994, 33, 972-981.

S5. Taylor, P. N.; Anderson, H. L. Cooperative self-assembly of double-strand porphyrin ladders. J. Am. Chem. Soc. 1999, 121, 11538-11545.

S6. Chang, M. Hoffman, M.-H.; Anderson, H. L.; Herz, L. M. Dynamics of excited-state conformational relaxation and electronic delocalization in conjugated porphyrin oligomers. J. Am. Chem. Soc. 2008, 130, 10171-10178.

S7. Strickler, S. J.; Berg, R. A. Relationship between absorption intensity and fluorescence lifetime of molecules. J. Chem. Phys. 1962, 37, 814-822.

S8. Reichardt, C. Solvatochromic dyes as solvent polarity indicators. Chem. Rev. 1994, 94, 2319-2358.

S9. Grimme, S.; Antony, J.; Ehrlich, S.; Krieg, H. A consistent and accurate ab initio parametrization of density functional dispersion correction (DFT-D) for the 94 elements H-Pu. J. Chem. Phys. 2010, 132, 154104.

S10. Grimme, S.; Ehrlich, S.; Goerigk, L. Effect of the damping function in dispersion corrected density functional theory. J. Comput. Chem. 2011, 32, 1456-1465.

S11. Kumar, N.; Saha, S.; Sastry, G. N. Towards developing a criterion to characterize non-covalent 
bonds: a quantum mechanical study. Phys. Chem. Chem. Phys. 2021, 23, 8478-8488.

S12. Rozas, I.; Alkorta, I.; Elguero, J. Behavior of ylides containing N, O, and C atoms as hydrogen bond acceptors. J. Am. Chem. Soc. 2000, 122, 11154-11161.

S13. Schleyer, P. v. R.; Maerker, C.; Dransfeld, A.; Jiao, H.; Hommes, N. J. R. v. E. J. Am. Chem. Soc. 1996, 118, 6317-6318.

S14, Fallah-Bagher-Shaidaei, H.; Wannere, C. S.; Corminboeuf, C.; Puchta, R.; Schleyer, R. v. R. Org. Lett. 2006, 8, 863-866.

S15. Kasha, M.; El-Bayoumi, M. A.; Rhodes, W. Excited states of nitrogen base-pairs and polynucleotides. J. Chim. Phys. 1961, 58, 916-925.

S16. Morisue, M.; Ueno, I. Preferential solvation unveiled by anomalous conformational equilibration of porphyrin dimers: Nucleation growth of solvent-solvent segregation. J. Phys. Chem. B 2018, 122, 5251-5259. 